Prepared in cooperation with the Capital Area Groundwater Conservation Commission; the Louisiana Department of Transportation and Development, Public Works and Water Resources Division; and the City of Baton Rouge and Parish of East Baton Rouge

\title{
Simulation of Groundwater Flow in the "1,500-Foot" Sand and "2,000-Foot" Sand, with Scenarios to Mitigate Saltwater Migration in the "2,000-Foot" Sand of the Baton Rouge Area, Louisiana
}

Scientific Investigations Report 2013-5227

Version 1.2, June 2014 



\section{Simulation of Groundwater Flow in the "1,500-Foot" Sand and "2,000-Foot" Sand, with Scenarios to Mitigate Saltwater Migration in the "2,000-Foot" Sand of the Baton Rouge Area, Louisiana}

By Charles E. Heywood, Jason M. Griffith, and John K. Lovelace

Prepared in cooperation with the Capital Area Groundwater Conservation Commission; the Louisiana Department of Transportation and Development, Public Works and Water Resources Division; and the City of Baton Rouge and Parish of East Baton Rouge

Scientific Investigations Report 2013-5227

Version 1.2, June 2014 


\title{
U.S. Department of the Interior SALLY JEWELL, Secretary
}

\section{U.S. Geological Survey Suzette M. Kimball, Acting Director}

\author{
U.S. Geological Survey, Reston, Virginia \\ First release: 2014, online \\ Revised: April 2014 (ver. 1.1), online \\ Revised: June 2014 (ver. 1.2), online
}

For more information on the USGS - the Federal source for science about the Earth, its natural and living resources, natural hazards, and the environment, visit http://www.usgs.gov or call 1-888-ASK-USGS.

For an overview of USGS information products, including maps, imagery, and publications, visit http://www.usgs.gov/pubprod

To order this and other USGS information products, visit http://store.usgs.gov

Any use of trade, firm, or product names is for descriptive purposes only and does not imply endorsement by the U.S. Government.

Although this information product, for the most part, is in the public domain, it also may contain copyrighted materials as noted in the text. Permission to reproduce copyrighted items must be secured from the copyright owner.

Suggested citation:

Heywood, C.E., Griffith, J.M., and Lovelace, J.K., 2014, Simulation of groundwater flow in the "1,500-foot" sand and "2,000-foot" sand, with scenarios to mitigate saltwater migration in the "2,000-foot" sand of the Baton Rouge area, Louisiana (ver. 1.2, June 2014): U.S. Geological Survey Scientific Investigations Report 2013-5227, 63 p., http://dx.doi.org/10.3133/sir20135227.

ISSN 2328-031X (print) ISSN 2328-0328 (online)

http://dx.doi.org/10.3133/sir20135227 


\section{Acknowledgments}

The authors would like to thank the many people who have contributed substantially to a better understanding of the hydrogeology and saltwater encroachment in the Baton Rouge area in southeastern Louisiana. Don C. Dial, Anthony J. Duplechin, Zahir "Bo" Bolourchi, and other members of the Capital Area Ground Water Conservation Commission provided guidance and assistance throughout this investigation. 



\section{Contents}

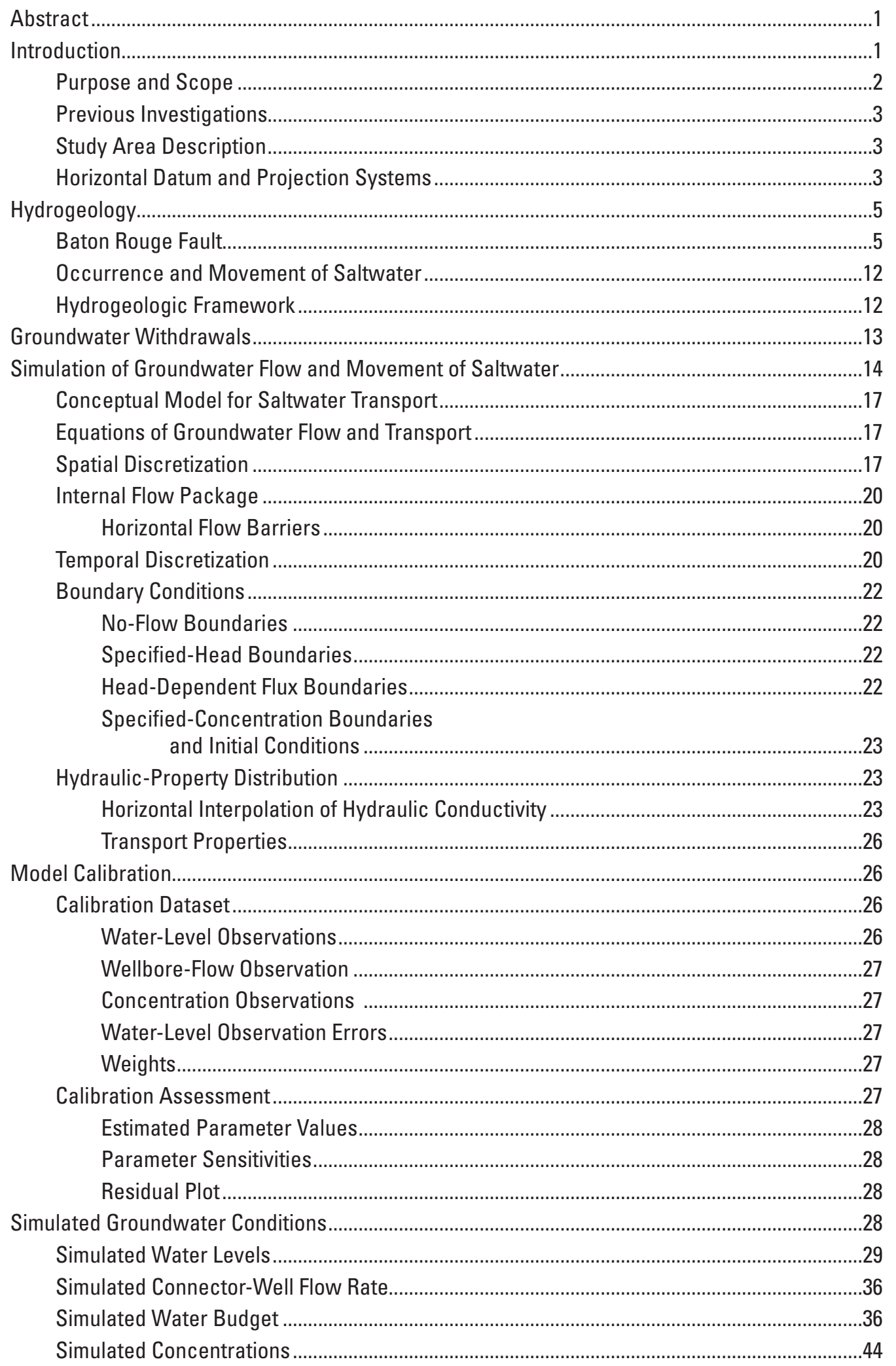


Limitations and Appropriate Use of the Model.

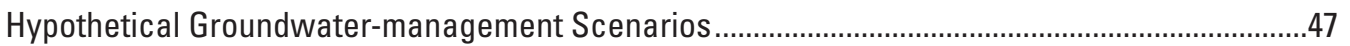

Scenario 1: Continued Groundwater Withdrawals at 2007 Rates .........................................48

Scenario 2: Reduction of Groundwater Withdrawals from the "1,500-foot" Sand ..................48

Scenario 3: Scavenger Well Withdrawal from the Base of the "2,000-foot" Sand ..................53

Scenario 4: Reduction of Groundwater Withdrawals from the

2,000-foot" Sand in the Baton Rouge Industrial District............................................53

Scenario 5: Cessation of Groundwater Withdrawals from the

"2,000-foot" Sand in the Baton Rouge Industrial District............................................53

Scenario 6: Scavenger Well Combined with a Reduction of 1.375 Million

Gallons Per Day of Industrial District Withdrawal from the

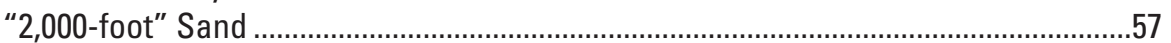

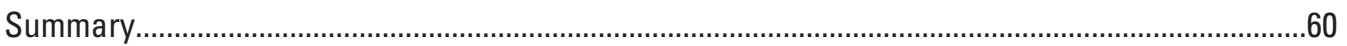

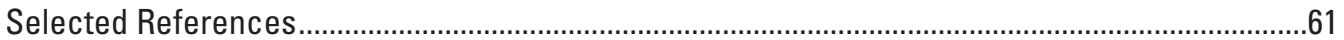

\section{Figures}

1. Map showing location of the study area, the Baton Rouge Fault, stratigraphic control wells, and simulated groundwater-withdrawal wells in southeastern Louisiana and southwestern Mississippi

2. Hydrogeologic section $A-A^{\prime}$ in East Baton Rouge and East and West Feliciana Parishes, southeastern Louisiana

3. Map showing simulated altitude of the top of the "1,500-foot" sand of the Baton Rouge area in southeastern Louisiana and southwestern Mississippi.

4. Map showing simulated thickness of the "1,500-foot" sand of the Baton Rouge area in southeastern Louisiana and southwestern Mississippi.

5. Map showing simulated altitude of the top of the "2,000-foot" sand of the Baton Rouge area in southeastern Louisiana and southwestern Mississippi.

6. Map showing simulated thickness of the "2,000-foot" sand of the Baton Rouge area in southeastern Louisiana and southwestern Mississippi.

7. Conceptual offset of hydrogeologic units at faults in the Baton Rouge area, southeastern Louisiana

8. Graph showing estimated withdrawals from the Baton Rouge sands, 1940-2007

9. Average daily withdrawal rate during 2007 at wells screened in the "2,000-foot" sand of the Baton Rouge area and located at or near the Baton Rouge industrial district in southeastern Louisiana

10. Map showing the model finite-difference grid and locations of the horizontal flow barrier in the "2,000-foot" sand of the Baton Rouge area and simulated groundwater-withdrawal wells in southeastern Louisiana and southwestern Mississippi.

11. Map showing the finite-difference grid and locations of horizontal flow barriers, simulated groundwater-withdrawal wells, and water-level observation wells in the "1,000-foot," "1,200-foot," "1,700-foot," "2,400-foot," and "2,800-foot" sands of the Baton Rouge area in the detailed model area in southeastern Louisiana.

12. North-to-south cross section along model column 24 showing aquifers, confining units, and finite-difference discretization 
13. Map showing pilot point locations and the simulated horizontal hydraulic conductivity distribution within the "2,000-foot" sand of the Baton Rouge area in the detailed model area in southeastern Louisiana

14. Graph showing residuals as a function of simulated water level altitudes for the "2,000-foot" sand and all other simulated aquifers. Residuals are calculated by subtracting simulated water-level altitudes from observed water-level altitudes

15. Map showing simulated steady-state water levels within the "1,500-foot" sand of the Baton Rouge area representing predevelopment conditions before 1940 in southeastern Louisiana and southwestern Mississippi.....

16. Map showing simulated steady-state water-levels within the "2,000-foot" sand of the Baton Rouge area representing predevelopment conditions before 1940 in southeastern Louisiana and southwestern Mississippi.....

17A. Maps showing simulated 2007 water levels within the "1,500-foot" sand of the Baton Rouge area in southeastern Louisiana and southwestern Mississippi

17B. Map showing simulated 2007 water levels within the "1,500-foot" sand of the Baton Rouge area in the detailed model area in southeastern Louisiana

18A. Map showing simulated 2007 water levels within the "2,000-foot" sand of the Baton Rouge area in southeastern Louisiana and southwestern Mississippi

18B. Map showing simulated 2007 water levels within the "2,000-foot sand of the Baton Rouge area in the detailed model area in southeastern Louisiana

19. Graphs showing simulated and observed water levels within the "1,000-foot" and "1,200-foot" sands of the Baton Rouge area in southeastern Louisiana

20. Graphs showing simulated and observed water levels within the "1,500-foot" sand of the Baton Rouge area in southeastern Louisiana

21. Graphs showing simulated and observed water levels within the "1,700-foot" sand of the Baton Rouge area in southeastern Louisiana

22. Graphs showing simulated and observed water levels within the "2,000-foot" sand of the Baton Rouge area in southeastern Louisiana

23. Graphs showing simulated and observed water levels within the "2,400-foot" sand of the Baton Rouge area in southeastern Louisiana

24. Graph showing simulated and observed water levels within the "2,800-foot" sand of the Baton Rouge area in southeastern Louisiana

25. Graph showing simulated groundwater withdrawals and flows from storage and specified-head boundaries.

26. Graph showing simulated and observed chloride concentrations at observation wells within the "2,000-foot" sand of the Baton Rouge area in southeastern Louisiana

27. Map showing simulated 2007 water levels and chloride concentrations at the base of the "2,000-foot" sand of the Baton Rouge area in the detailed model area in southeastern Louisiana

28. Map showing predicted 2047 water levels within the "1,500-foot" sand of the Baton Rouge area in the detailed model area in southeastern Louisiana after continued pumping at 2007 rates (scenario 1)

29. Map showing predicted 2047 water levels and chloride concentrations at the base of the "2,000-foot" sand of the Baton Rouge area in the detailed model area in southeastern Louisiana after continued pumping at 2007 rates (scenario 1) 
30. Graphs showing predicted chloride concentrations at the base of the "2,000-foot" sand after continued pumping at 2007 rates (scenario 1), installation of a scavenger well (scenario $3 \mathrm{a}, \mathrm{b}$ ), industrial-district withdrawal reduction of 3.6 million gallons per day (scenario 4), cessation of industrialdistrict withdrawals from the "2,000-foot" sand (scenario 5), and a scavenger well with withdrawal reductions (scenario 6) for: $A$, well EB-1028; $B$, well EB-1150; $C$, well EB-630; $D$, well EB-781; $E$, well EB-807B; and $F$, hypothetical well EB-X.

31. Map showing predicted 2047 water levels within the "1,500-foot" sand of the Baton Rouge area in the detailed model area in southeastern Louisiana following cessation of pumping from selected industrial wells in the "1,500-foot" and "1,700-foot" sands beginning in 2015 (scenario 2)

32. Map showing predicted 2047 water levels and chloride concentrations at the base of the "2,000-foot" sand of the Baton Rouge area in the detailed model area in southeastern Louisiana after pumping at a rate of 2 million gallons per day from a simulated scavenger well located in model row 57 and column 26 beginning in 2017 (scenario 3).

33. Map showing predicted 2047 water levels and chloride concentrations at the base of the "2,000-foot" sand of the Baton Rouge area in the detailed model area in southeastern Louisiana after pumping at a rate of 2 million gallons per day from a simulated scavenger well located in model row 68 and column 30 starting in 2017 (scenario 3).

34. Map showing predicted 2047 water levels and chloride concentrations at the base of the "2,000-foot" sand of the Baton Rouge area in the detailed model area in southeastern Louisiana after a 3.6 million gallon per day reduction in pumping (from 2007 rates) at selected wells in the Baton Rouge industrial district beginning in 2015 (scenario 4)

35. Map showing predicted 2047 water levels and chloride concentrations at the base of the "2,000-foot" sand of the Baton Rouge area in the detailed model area in southeastern Louisiana following cessation of pumping from the "2000-foot" sand in the Baton Rouge industrial district beginning in 2015 (scenario 5)

36. Map showing predicted 2047 water levels and chloride concentrations at the base of the "2,000-foot" sand of the Baton Rouge area in the detailed model area in southeastern Louisiana after 31 years of pumping from a scavenger well located in model row 68 and column 30 beginning in 2017 and reduced withdrawals at selected industrial and public supply wells beginning in 2015 (scenario 6)

\section{Tables}

1. Groundwater withdrawals (in million gallons per day) in the Baton Rouge area, Louisiana, by parish and principal use, 2010

2. Aquifers and aquifer systems in southern Mississippi and southeastern Louisiana and corresponding model layers

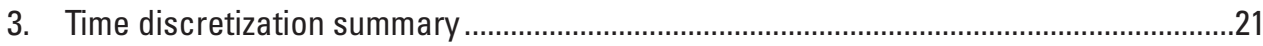

4. Parameter values and sensitivities for the calibrated groundwater-flow model ...........24

5. Simulated steady-state and transient flow rates ............................................................

6. Simulated plume areas and chloride concentrations ....................................................48 


\section{Conversion Factors}

Inch/Pound to SI

\begin{tabular}{|c|c|c|}
\hline Multiply & By & To obtain \\
\hline \multicolumn{3}{|c|}{ Length } \\
\hline foot $(\mathrm{ft})$ & 0.3048 & meter $(\mathrm{m})$ \\
\hline mile (mi) & 1.609 & kilometer $(\mathrm{km})$ \\
\hline \multicolumn{3}{|c|}{ Area } \\
\hline square foot $\left(\mathrm{ft}^{2}\right)$ & 0.09290 & square meter $\left(\mathrm{m}^{2}\right)$ \\
\hline square mile $\left(\mathrm{mi}^{2}\right)$ & 2.590 & square kilometer $\left(\mathrm{km}^{2}\right)$ \\
\hline acre & 4,047 & square meter $\left(\mathrm{m}^{2}\right)$ \\
\hline \multicolumn{3}{|c|}{ Volume } \\
\hline gallon (gal) & 0.003785 & cubic meter $\left(\mathrm{m}^{3}\right)$ \\
\hline cubic foot $\left(\mathrm{ft}^{3}\right)$ & 0.02832 & cubic meter $\left(\mathrm{m}^{3}\right)$ \\
\hline \multicolumn{3}{|c|}{ Flow rate } \\
\hline cubic foot per day $\left(\mathrm{ft}^{3} / \mathrm{d}\right)$ & 0.02832 & cubic meter per day $\left(\mathrm{m}^{3} / \mathrm{d}\right)$ \\
\hline gallon per minute (gal/min) & 0.06309 & liter per second $(\mathrm{L} / \mathrm{s})$ \\
\hline gallon per day (gal/d) & 0.003785 & cubic meter per day $\left(\mathrm{m}^{3} / \mathrm{d}\right)$ \\
\hline million gallons per day (Mgal/d) & 0.04381 & cubic meter per second $\left(\mathrm{m}^{3} / \mathrm{s}\right)$ \\
\hline \multicolumn{3}{|c|}{ Density } \\
\hline pound per cubic foot $\left(\mathrm{lb} / \mathrm{ft}^{3}\right)$ & 16.02 & kilogram per cubic meter $\left(\mathrm{kg} / \mathrm{m}^{3}\right)$ \\
\hline pound per cubic foot $\left(\mathrm{lb} / \mathrm{ft}^{3}\right)$ & 0.01602 & gram per cubic centimeter $\left(\mathrm{g} / \mathrm{cm}^{3}\right)$ \\
\hline \multicolumn{3}{|c|}{ Hydraulic conductivity } \\
\hline foot per day (ft/d) & 0.3048 & meter per day $(\mathrm{m} / \mathrm{d})$ \\
\hline
\end{tabular}

Temperature in degrees Fahrenheit $\left({ }^{\circ} \mathrm{F}\right)$ may be converted to degrees Celsius $\left({ }^{\circ} \mathrm{C}\right)$ as follows:

${ }^{\circ} \mathrm{C}=\left({ }^{\circ} \mathrm{F}-32\right) / 1.8$

Vertical coordinate information is referenced to the National Geodetic Vertical Datum of 1929 (NGVD 29).

Horizontal coordinate information is referenced to the North American Datum of 1983 (NAD 83).

Altitude, as used in this report, refers to distance above the vertical datum.

Concentrations of chemical constituents in water are given in milligrams per liter (mg/L). 


\section{Abbreviations}

$\begin{array}{ll}\text { City-Parish } & \text { City of Baton Rouge and Parish of East Baton Rouge } \\ \text { Commission } & \text { Capital Area Groundwater Conservation Commission } \\ \text { DOTD } & \text { Louisiana Department of Transportation and Development } \\ \text { DNR } & \text { Louisiana Department of Natural Resources } \\ \text { FHB } & \text { Flow and Head Boundary package } \\ \text { gpm } & \text { Gallons per minute } \\ \text { GIS } & \text { Geographic information system } \\ \text { HOB } & \text { Head Observation Package } \\ \text { HUF } & \text { Hydrogeologic-Unit Flow package } \\ \text { IMT } & \text { Integrated Mass Transport package } \\ \text { Mgal/d } & \text { Million gallons per day } \\ \text { mg/L } & \text { Milligram per liter } \\ \text { MNW2 } & \text { Multi-Node Well package } \\ \text { NWIS } & \text { National Water Information System } \\ \text { RASA } & \text { Regional Aquifer System Analysis } \\ \text { TVD } & \text { Total Variation Diminishing scheme } \\ \text { USGS } & \text { U.S. Geological Survey } \\ \text { VDF } & \text { Variable-Density Flow package } \\ {[M]} & \text { Mass dimension } \\ {[\text { L] }} & \text { Length dimension } \\ \text { [T] } & \text { Time dimension }\end{array}$




\title{
Simulation of Groundwater Flow in the "1,500-Foot" Sand and "2,000-Foot" Sand, with Scenarios to Mitigate Saltwater Migration in the "2,000-Foot" Sand of the Baton Rouge Area, Louisiana
}

\author{
By Charles E. Heywood, Jason M. Griffith, and John K. Lovelace
}

\section{Abstract}

Groundwater withdrawals have caused saltwater to encroach into freshwater-bearing aquifers beneath Baton Rouge, Louisiana. Groundwater investigations in the 1960s identified a freshwater-saltwater interface located at the Baton Rouge Fault, across which abrupt changes in water levels occur. Aquifers south of the fault generally contain saltwater, and aquifers north of the fault contain freshwater, though limited saltwater encroachment has been detected within 7 of the 10 aquifers north of the fault. The 10 aquifers beneath the Baton Rouge area, which includes East and West Baton Rouge Parishes, Pointe Coupee Parish, and East and West Feliciana Parishes, provided about 167 million gallons per day (Mgal/d) for public supply and industrial use in 2010. Groundwater withdrawals from the "2,000-foot" sand in East Baton Rouge Parish have caused water-level drawdown as great as 356 feet (ft) and induced saltwater movement northward across the fault. Saltwater encroachment threatens industrial wells that are located about 3 miles north of the fault. Constant and variable-density groundwater models were developed with the MODFLOW and SEAWAT groundwater modeling codes to evaluate strategies to control saltwater migration, including changes in the distribution of groundwater withdrawals and installation of "scavenger" wells to intercept saltwater before it reaches existing production wells.

Six hypothetical scenarios simulated the effects of different groundwater withdrawal options on groundwater levels within the "1,500-foot" sand and the "2,000-foot" sand and the transport of saltwater within the "2,000-foot" sand during 2008-47. Scenario 1 is considered a base case for comparison to the other five scenarios and simulates continuation of 2007 reported groundwater withdrawals. Scenario 2 simulates discontinuation of withdrawals from seven selected industrial wells located in the northwest corner of East Baton Rouge Parish and predicts that water levels within the "1,500-foot" sand will be about 10 to $12 \mathrm{ft}$ higher with this withdrawal reduction than under scenario 1. Scenario 3 simulates the effects of a scavenger well on water levels and chloride concentrations within the "2,000-foot" sand. The scavenger well, which withdraws water from the base of the "2,000-foot" sand at a rate of $2.0 \mathrm{Mgal} / \mathrm{d}$, is simulated at two possible locations. In comparison to the concentrations simulated in scenario 1, operation of the scavenger well at the locations specified in scenario 3 reduces the chloride concentrations at all existing chloride-observation well locations. Scenario 4 simulates a $3.6 \mathrm{Mgal} / \mathrm{d}$ reduction in total groundwater withdrawals from selected wells screened in the "2,000-foot" sand that are located in the Baton Rouge industrial district. Under scenario 4, chloride concentrations decrease in the leading portion of the plume south of the industrial district but increase in areas farther east. Scenario 5 simulates the effects of total cessation of withdrawals from the "2,000-foot" sand in the industrial district, which causes a change in the groundwater-flow direction toward municipal supply wells and increased chloride concentrations in the area where municipal supply wells are located. Scenario 6 simulates the combined effect of withdrawal reductions from the "2,000-foot" sand and operation of a scavenger well and was most effective at decreasing the size of the plume area and median and mean chloride concentrations within the "2000-foot" sand in the Baton Rouge area.

\section{Introduction}

Fresh groundwater is a valuable resource in southeastern Louisiana and the five-parish Baton Rouge area (subsequently referred to as the "Baton Rouge area"), which includes East and West Baton Rouge, Pointe Coupee, and East and West Feliciana Parishes. In the Baton Rouge area, fresh groundwater in most aquifers is soft, sodium bicarbonate water with a dissolved-solids concentration of about 200 milligrams per liter (mg/L) (Meyer and Turcan, 1955) and requires little treatment for potable use or industrial purposes (Stuart and others, 1994). Groundwater withdrawals in the Baton Rouge area since the 1940s have lowered water levels 
in the "2000-foot" sand as much as 356 feet (ft) and altered groundwater-flow directions in most of the 10 underlying freshwater-bearing aquifers. During 2010, about 196 million gallons per day $(\mathrm{Mgal} / \mathrm{d})$ of groundwater were withdrawn (table 1) in the Baton Rouge area (Sargent, 2011), mostly in East Baton Rouge Parish. Groundwater usage in 2010 was primarily for public supply and industry, which consumed about $94 \mathrm{Mgal} / \mathrm{d}$ and $73 \mathrm{Mgal} / \mathrm{d}$, respectively. Withdrawals from "1,500-foot" and "2,000-foot" sands of the Baton Rouge area in 2010 were about $19.9 \mathrm{Mgal} / \mathrm{d}$ and $23.9 \mathrm{Mgal} / \mathrm{d}$, or 10.2 percent and 12.2 percent of the total withdrawals, respectively (P. Sargent, U.S. Geological Survey, written commun., 2013). The drawdown of groundwater levels has caused saltwater to encroach into freshwater areas near Baton Rouge. Saltwater encroachment has been detected in seven aquifers, including the "1,500-foot" sand and the "2,000-foot" sand in East Baton Rouge Parish (Meyer and Turcan, 1955; Morgan, 1961; Tomaszewski, 1996; Lovelace, 2007). Saltwater threatens industrial wells which, in recent years, have typically accounted for about twothirds of the withdrawals from the "2,000-foot" sand in East Baton Rouge Parish.

Water planners and managers need to have additional knowledge of the effects of groundwater withdrawals on the rate and pathways of saltwater migration and to assess possible management strategies that could control further saltwater encroachment in the Baton Rouge area. In response to this concern, the U.S. Geological Survey (USGS), in cooperation with the Capital Area Ground Water Conservation Commission (Commission), Louisiana Department of Transportation and Development (DOTD) Water Resources Office, and the City of Baton Rouge and Parish of East Baton Rouge (City-Parish), developed the groundwater-flow and saltwater-transport model of the Southern Hills regional aquifer system that is documented in this report. The model simulates the effects of reported groundwater withdrawals on groundwater flow in the "1,500-foot" sand and "2,000-foot" sand, and the movement of saltwater in the "2,000-foot" sand northward from the Baton Rouge Fault in East Baton Rouge Parish. The model simulates historical conditions (prior to 2008) and six possible future pumping scenarios and can be used to evaluate possible strategies to mitigate saltwater encroachment in the "2,000-foot" sand in the Baton Rouge area. The model provides a tool for evaluation of the need, effectiveness, and possible locations of additional pumping, injection, or observation wells that may either mitigate or be used to monitor saltwater encroachment. The model also provides a framework for future studies of groundwater flow and saltwater encroachment in other aquifers within the groundwater-flow system. It could also facilitate study of possible saltwater-encroachment mitigation strategies and increase understanding of saltwater movement in similar hydrogeologic settings. A digital archive of the groundwater model is on file at the USGS office in Baton Rouge.

\section{Purpose and Scope}

This report documents the hydrogeologic framework of the Southern Hills regional aquifer system in southeastern Louisiana and in southwestern Mississippi, the hydraulic properties of the aquifer system, groundwater-withdrawal rates, and the development and calibration of a groundwaterflow and saltwater-transport model that simulates groundwater flow in the "1,500-foot" sand and "2,000-foot" sand and migration of saltwater within the "2,000-foot" sand in the Baton Rouge area. The simulated effects of groundwater withdrawals on water levels and flow directions in the "2,000-foot" sand and "1,500-foot" sand and on the movement of saltwater in the "2,000-foot" sand are described. Six future scenarios are discussed that represent the effects of continued groundwater withdrawals and possible strategies to mitigate saltwater encroachment in the " 2,000 -foot" sand beneath the city of Baton Rouge.

Table 1. Groundwater withdrawals (in million gallons per day) in the Baton Rouge area, Louisiana, by parish and principal use, 2010 (modified from Sargent, 2011).

\begin{tabular}{|c|c|c|c|c|c|c|c|c|c|}
\hline \multirow[t]{2}{*}{ Parish } & \multirow{2}{*}{$\begin{array}{l}\text { Public } \\
\text { supply }\end{array}$} & \multirow[t]{2}{*}{ Industrial } & \multirow{2}{*}{$\begin{array}{c}\text { Power } \\
\text { generation }\end{array}$} & \multirow{2}{*}{$\begin{array}{c}\text { Rural } \\
\text { domestic }\end{array}$} & \multirow[t]{2}{*}{ Livestock } & \multicolumn{2}{|c|}{ Irrigation } & \multirow{2}{*}{$\begin{array}{l}\text { Aqua- } \\
\text { culture }\end{array}$} & \multirow[t]{2}{*}{ Total use } \\
\hline & & & & & & Rice & General & & \\
\hline East Feliciana & 3.00 & 0.03 & 0.00 & 0.27 & 0.02 & 0.00 & 0.18 & 0.00 & 3.50 \\
\hline Pointe Coupee & 4.08 & 4.92 & 1.89 & 0.23 & 0.10 & 4.78 & 7.19 & 4.34 & 27.53 \\
\hline $\begin{array}{l}\text { West } \\
\text { Feliciana }\end{array}$ & 4.15 & 0.41 & 0.02 & 0.10 & 0.00 & 0.00 & 0.00 & 0.00 & 4.68 \\
\hline Total & 93.56 & 73.08 & 9.70 & 0.93 & 0.34 & 4.78 & 7.97 & 5.45 & 195.81 \\
\hline
\end{tabular}


The model and scenarios in this report supercede those previously documented by Heywood and Griffith (2013). Differences from the previous version include the addition of water-level observations from 2008 to 2011, model modification and recalibration to improve simulation of the " 1,500 -foot" and "2,400-foot" sands, modification of the timing for all hypothetical groundwater management scenarios, and inclusion of an additional scenario.

The model domain encompasses an area of about 6,600 square miles $\left(\mathrm{mi}^{2}\right)$ in southeastern Louisiana and southwestern Mississippi; however, its primary focus is on the "1,500-foot" sand and "2,000-foot" sand in a $25-\mathrm{mi}^{2}$ area in Baton Rouge where large groundwater withdrawals have occurred and where saltwater encroachment is of concern. Simulation of regional groundwater flow through all hydrogeologic units in the Southern Hills aquifer system helped assure reasonable simulated results within the primary area of concern.

\section{Previous Investigations}

Several previous reports included background data on the geologic, hydraulic, and water-quality characteristics of freshwater-bearing aquifers in the Baton Rouge area (Meyer and Turcan, 1955; Morgan, 1961). Morgan and Winner (1964) documented known areas of saltwater in aquifers underlying East and West Baton Rouge Parishes and estimated the rates of saltwater movement toward areas of large groundwater withdrawals in the industrial district and toward public-supply pumping stations. Whiteman (1979) included a detailed discussion of saltwater encroachment in the " 600 -foot" sand and "1,500-foot" sand and discussions of saltwater in other aquifers. Whiteman (1979) also documented the existence of the eastwest trending Baton Rouge Fault as a leaky hydrologic barrier that limits northward movement of saltwater in aquifers in the Baton Rouge area. Buono (1983) described the freshwaterbearing aquifers in the northern parishes of southeastern Louisiana (including those in the Baton Rouge area) and the up-dip equivalent aquifers in Mississippi as an interdependent system, which he named the "Southern Hills regional aquifer system" (table 1). Griffith (2003) presented hydrogeologic cross sections of the freshwater aquifers in southeastern Louisiana, which he described as a sequence of complexly interbedded, interconnected, lenticular (lens shaped), alluvial, freshwaterbearing, clayey, sandy, and graveliferous strata. Morgan and Winner (1964), Whitman (1979), Tomaszewski (1996), and Lovelace (2007) documented the occurrence of saltwater and increasing chloride concentrations within various aquifers in the Baton Rouge area.

In 1975, the USGS began a cooperative program with the DOTD and the Commission to analyze groundwater flow by using groundwater models of aquifers in the Baton Rouge area, including the " 400 -foot" sand, " 600 -foot" sand, " 1,500 -foot" sand, "1,700-foot" sand, and "2,000-foot" sand in the Baton Rouge area (Torak and Whiteman, 1982; Huntzinger and others,
1985; Kuniansky, 1989; Halford and Lovelace, 1994). Under the USGS regional aquifer-system analysis (RASA) program, the hydrogeologic framework, groundwater chemistry, and regional flow patterns in the freshwater aquifers along the northern Gulf of Mexico Coast in Louisiana and parts of Texas and Mississippi were described, and groundwater-flow models were used to simulate regional flow patterns (Martin and Whiteman, 1990).

\section{Study Area Description}

The study area encompasses about $6,600 \mathrm{mi}^{2}$ in southeastern Louisiana and southwestern Mississippi (fig. 1). The study area extends southward from about 25 miles (mi) north of the Mississippi state line to Gonzales, La., in the south and eastward from Breaux Bridge, La., in the west to Hammond, La., in the east. In southeastern Louisiana, all or parts of Ascension, Assumption, Avoyelles, Concordia, East and West Baton Rouge, East and West Feliciana, Iberville, Livingston, Pointe Coupee, St. Helena, St. Martin, St. Landry, and Tangipahoa Parishes are in the study area. In Mississippi, all or parts of Adams, Amite, Franklin, Lincoln, Pike, and Wilkinson Counties are in the study area.

The terrain in the study area varies from forested rolling hills in the north to flat lowlands and swamps in the south. The Mississippi River valley dominates the setting near the western and southern boundaries of the study area. Landsurface altitudes range from $0 \mathrm{ft}$ to more than $450 \mathrm{ft}$ (Calhoun and Frois, 1997). The climate is subtropical, warm, and temperate with an average annual temperature of $68^{\circ} \mathrm{F}\left(20^{\circ} \mathrm{C}\right)$ and an average annual rainfall of 61 inches (National Oceanic and Atmospheric Administration, 1995).

About 1 million people live within the study area, with largest populations in the Baton Rouge metropolitan area (U.S. Census Bureau, 2010). All of the public water supplied in the Baton Rouge area in 2010 was groundwater (Sargent, 2011). Several industrial facilities, primarily located along the Mississippi River, also utilize the groundwater resources in the study area (table 1). In addition, groundwater supplies about 84 percent of agricultural water use in the study area (Sargent, 2011).

\section{Horizontal Datum and Projection Systems}

The geographic coordinates of database features, such as well-head locations, and geographic information system (GIS) data used in the model are referenced to the North American Datum of 1983 (NAD 83). To represent model-cell areas accurately, polygon and point GIS coverages of the model finite-difference cells and nodes, created with the program MODELGRID (Kernodle and Philip, 1988), were generated in a Lambert Conformal Conic projection system. The model finite-difference grid columns are oriented north-south in the Lambert Conformal Conic projection system. These GIS coverages were subsequently projected into the Universal 


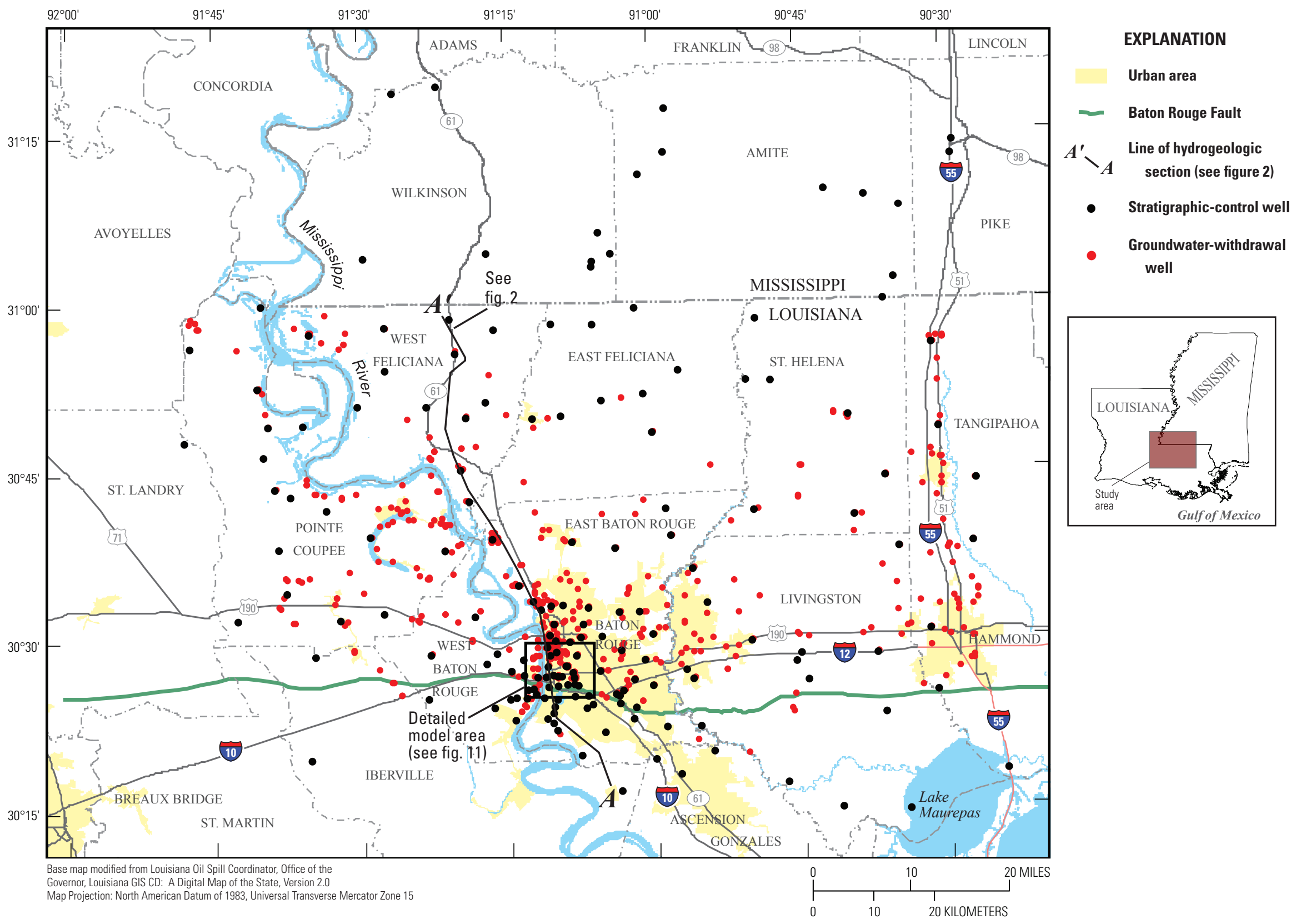

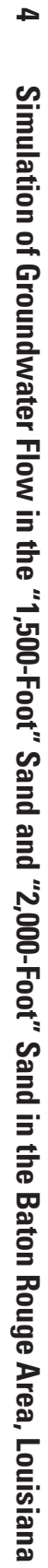

Figure 1. Map showing location of the study area, the Baton Rouge Fault, stratigraphic control wells, and simulated groundwater-withdrawal wells in southeastern Louisiana and southwestern Mississippi. 
Transverse Mercator (UTM) zone 15 coordinate system that was used for GIS coverages of wells, the hydrogeologic framework, and water levels. Consequently, the model finite difference grid appears slightly rotated in the UTM projection displayed in the map figures in this report. Projection and coordinate system details are contained in a file in the digital model archive.

\section{Hydrogeology}

Aquifers containing freshwater in the Baton Rouge area are generally part of the Southern Hills regional aquifer system and include the Mississippi River alluvial aquifer, the shallow sands of the Baton Rouge area, the upland terrace aquifer, the "400-foot" sand, "600-foot" sand, "800-foot" sand, "1,000foot" sand, "1,200-foot" sand, "1,500-foot" sand, "1,700-foot" sand, "2,000-foot" sand, "2,400-foot" sand, and "2,800-foot" sand of the Baton Rouge area and the Catahoula aquifer (Meyer and Turcan, 1955; Morgan, 1961; Buono, 1983; Griffith, 2003). The Mississippi River alluvial aquifer and the shallow sands of the Baton Rouge area are the shallowest aquifers in the Baton Rouge area. Deeper aquifers in the Baton Rouge area include aquifers that are named for their depth of occurrence in the Baton Rouge industrial district (table 2; fig. 2) and the Catahoula aquifer. Aquifers in the Baton Rouge area have been correlated with aquifers in southern Mississippi and in Louisiana parishes east of the study area. The aquifers also have been grouped based on correlative units in southwestern and central Louisiana into the Chicot equivalent, Evangeline equivalent, Jasper equivalent, and Catahoula equivalent aquifer systems (Stuart and others, 1994). Although the Catahoula aquifer contains freshwater in some areas, it is generally too deep and contains too much saltwater to be an economically viable water resource in the Baton Rouge area (Griffith, 2003).

Freshwater-bearing aquifers in the Baton Rouge area range in composition from very fine to coarse sand with some pea-to-cobble-sized gravel (Griffith, 2003) and are sufficiently permeable to yield economically substantial quantities of water to wells (Bates and Jackson, 1984). The aquifers are separated by confining units composed of material ranging from solid clay to sandy and silty clay that limit vertical groundwater flow. The freshwater aquifers and intervening confining units in the Baton Rouge area, together with the up-dip equivalent units in southwestern Mississippi, form a thickening wedge that dips to the south and southwest toward the Gulf of Mexico and Mississippi River valley (fig. 2). The confining units generally pinch out northward, and deeper aquifers coalesce with overlying surficial aquifers.

The average annual precipitation over the study area is 54 to 60 inches, and precipitation in the northern part of the study area (fig. 1) and farther north in Mississippi is the primary source of recharge to the aquifer system. Because the aquifers are interconnected, precipitation that infiltrates through the shallow, surficial aquifers located in recharge areas flows southward into deeper aquifers. Kuniansky (1989) estimated a range from 0.2 to 4.6 inches per year (in/yr) for deep regional aquifer recharge. Groundwater velocities range from a few tens of feet per year to several hundreds of feet per year (Buono, 1983).

The "1,500-foot" sand and "2,000-foot" sand, like other freshwater aquifers in the study area, generally dip and thicken to the south and consist of single or multiple 65- to 95-ft thick intervals of fine to medium sand and 100 to $300 \mathrm{ft}$ of medium sand. Where the aquifers contain multiple sand intervals, the intervals are separated by clays. The top of the "1,500-foot" sand is about 1,500 ft deep $1 \mathrm{mi}$ north of the Baton Rouge Fault but is displaced deeper south of the fault (fig. 3). The " 1,500 -foot" sand is continuous throughout the study area except in parts of Avoyelles, East and West Baton Rouge, Iberville, Livingston, and Point Coupee Parishes and in most of Mississippi (fig. 4). The top of the "2,000-foot" sand is about 2,000 ft deep $1 \mathrm{mi}$ north of the Baton Rouge Fault but is also displaced deeper south of the fault (fig. 5). The "2,000foot" sand is continuous throughout the study area (fig. 6). The location and thickness of the aquifers in Mississippi are based on the correlation of the "1,500-foot" sand and "2,000-foot" sand in the Baton Rouge area with up-dip units in southwestern Mississippi (Meyer and Turcan, 1955; Morgan, 1961; Newcome, 1975; Huntzinger and others, 1985; Griffith, 2003.)

\section{Baton Rouge Fault}

The Baton Rouge Fault extends across the southern part of the study area (fig. 2) and is part of a series of east-west trending faults in southern Louisiana (Murray, 1961; Hanor, 1982; Griffith, 2003). The location of the Baton Rouge Fault was documented in the 1960s and 1970s after the importance of the fault as a barrier to groundwater flow in the aquifers in the Baton Rouge area became apparent (Meyer and Rollo, 1965; Whiteman, 1979). McCulloh (1991) mapped the detailed location of the surface expression of faults through East Baton Rouge Parish. Within the study area, the Baton Rouge Fault dips to the south at angles between about 65 degrees and 70 degrees (Durham and Peeples, 1956; Smith and Kazmann, 1978; Whiteman, 1979; Roland and others, 1981; Hanor, 1982; McCulloh, 1991; Griffith, 2003, 2006).

Sediment deformation and displacement of sedimentary layers across the fault reduce the hydraulic connections between aquifers, thereby impeding horizontal groundwater flow, which causes substantial changes in both water levels and water quality across the fault. The displacement of aquifers across the Baton Rouge Fault ranges from about $20 \mathrm{ft}$ near the ground surface to about $300 \mathrm{ft}$ at altitudes of $-1,600$ to $-3,000 \mathrm{ft}$ (fig. 2 ). In the Baton Rouge area, the displacement of the " 1,500 foot" sand and "2,000-foot" sand at the Baton Rouge Fault are about 235 and $250 \mathrm{ft}$, respectively (Durham and Peeples, 1956; Meyer and Rollo, 1965; Smith and Kazmann, 1978; Whiteman, 1979; Roland and others, 1981; Hanor, 1982; McCulloh, 1991; Griffith, 2003, 2006). 


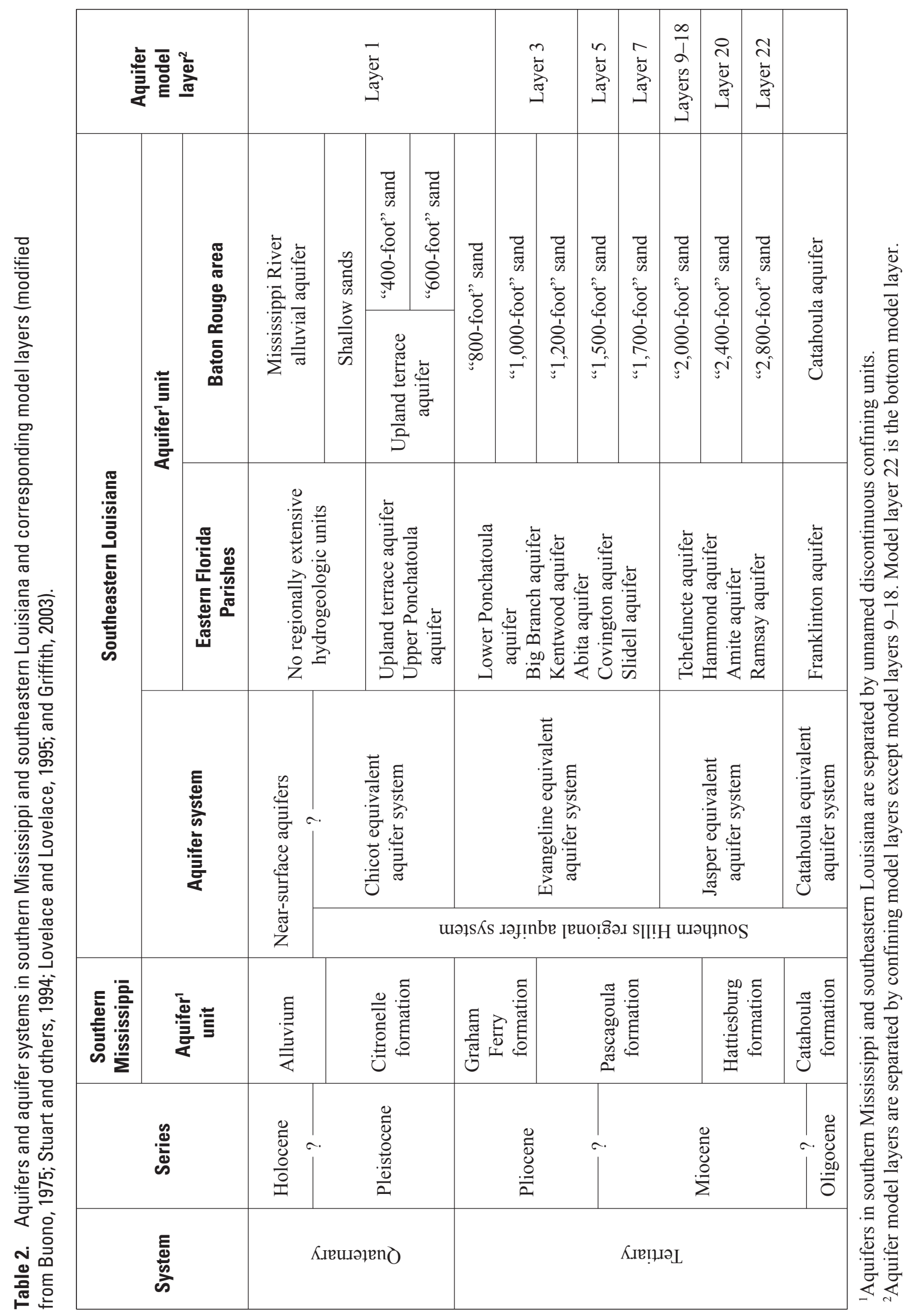




\section{EXPLANATION}

Hydrogeologic unit-Shows the generalized location of the hydrogeologic units.

Hydrogeologic framework layers-Shows the
location of hydrogeologic layers. Aquifer layers diagram of hydrogeologic framework layers.

Layer 1-Mississippi River alluvial aquifer, shallow sands, upland terrace aquifer, and the "400-,"

Layer 3-"1,000-" and "1,200-foot" sand

Layer 5-" 1,500 -foot" sand

Layer 7-"1,700-foot" sand

Layers 9 to $18-" 2,000-$ foot" sand

Layer 20-"2,400-foot" sand

Layer 22-"2,800-foot" sand

Intervening confining unit layer

Lithologic contact-Separates clay and sand units. Dashed where approximate. Queried where

1lb Faut

ydrogeologic contact-defines boundary

Well-Shows name and location of well.

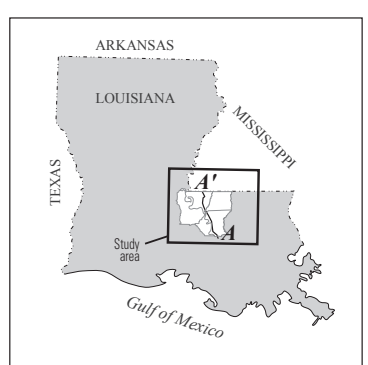

NORTH

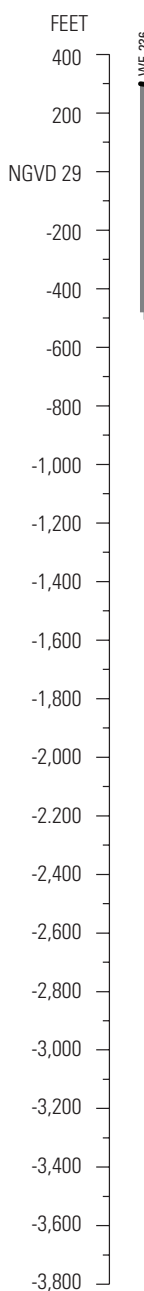

ST FRANCISVILLE

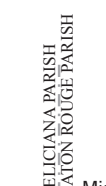

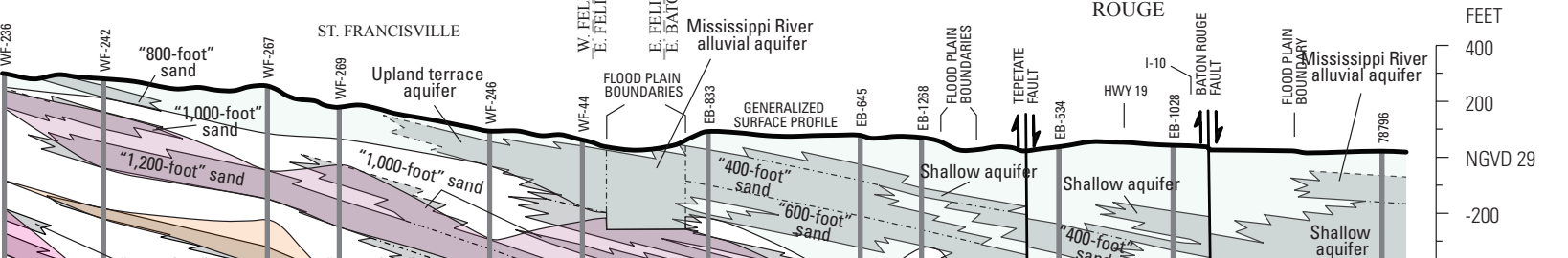

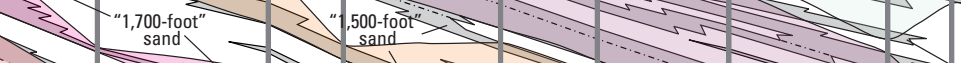

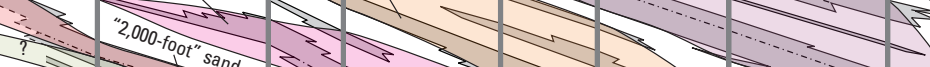

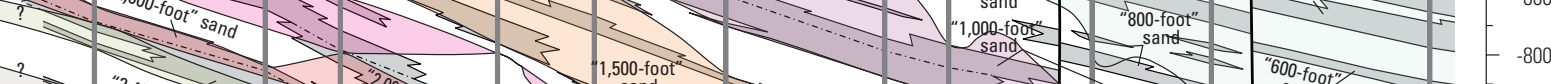
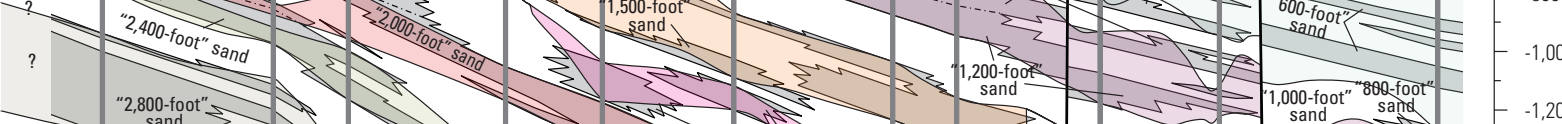

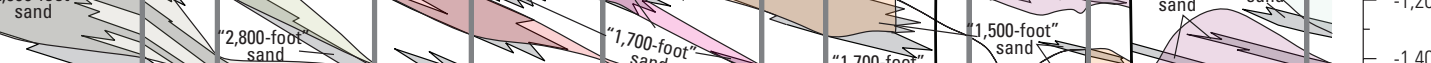
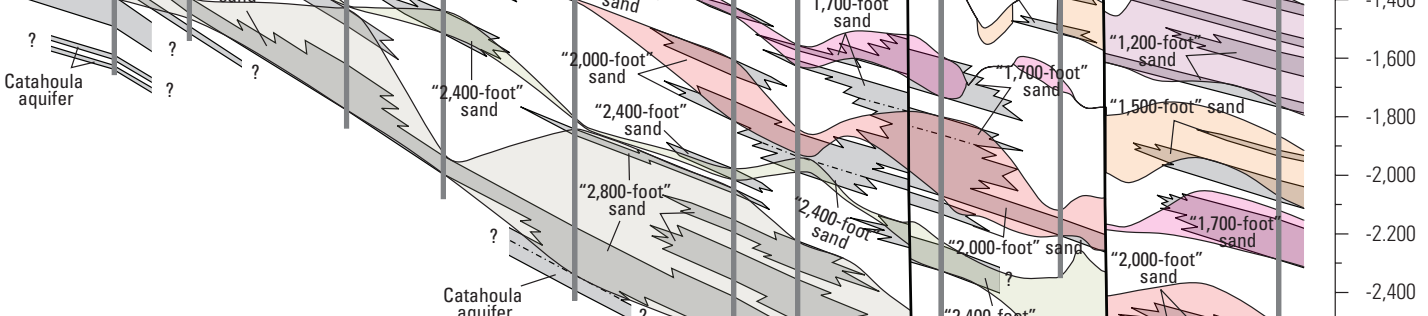

?

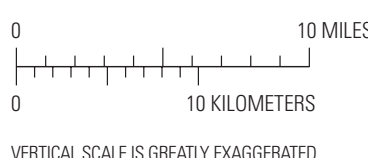

VERTICAL SCALE IS GREATLY EX

Datum is National Geodetic Vertical Datum of 1929 (NGVD 29)

Figure 2. Hydrogeologic section A-A' in East Baton Rouge and East and West Feliciana Parishes, southeastern Louisiana. Figure modified from Griffith (2003). 


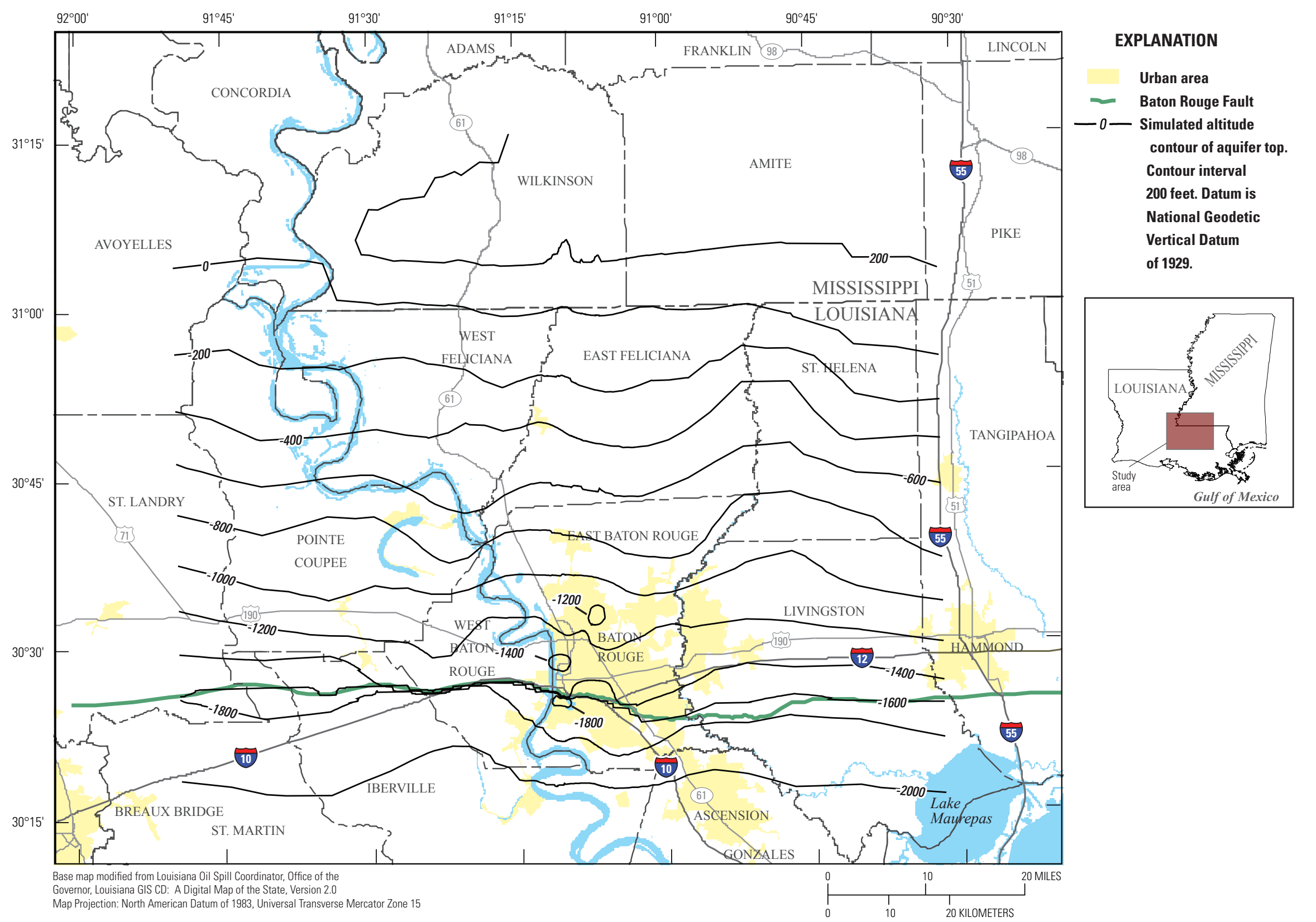

Figure 3. Map showing simulated altitude of the top of the "1,500-foot" sand of the Baton Rouge area in southeastern Louisiana and southwestern Mississippi. 


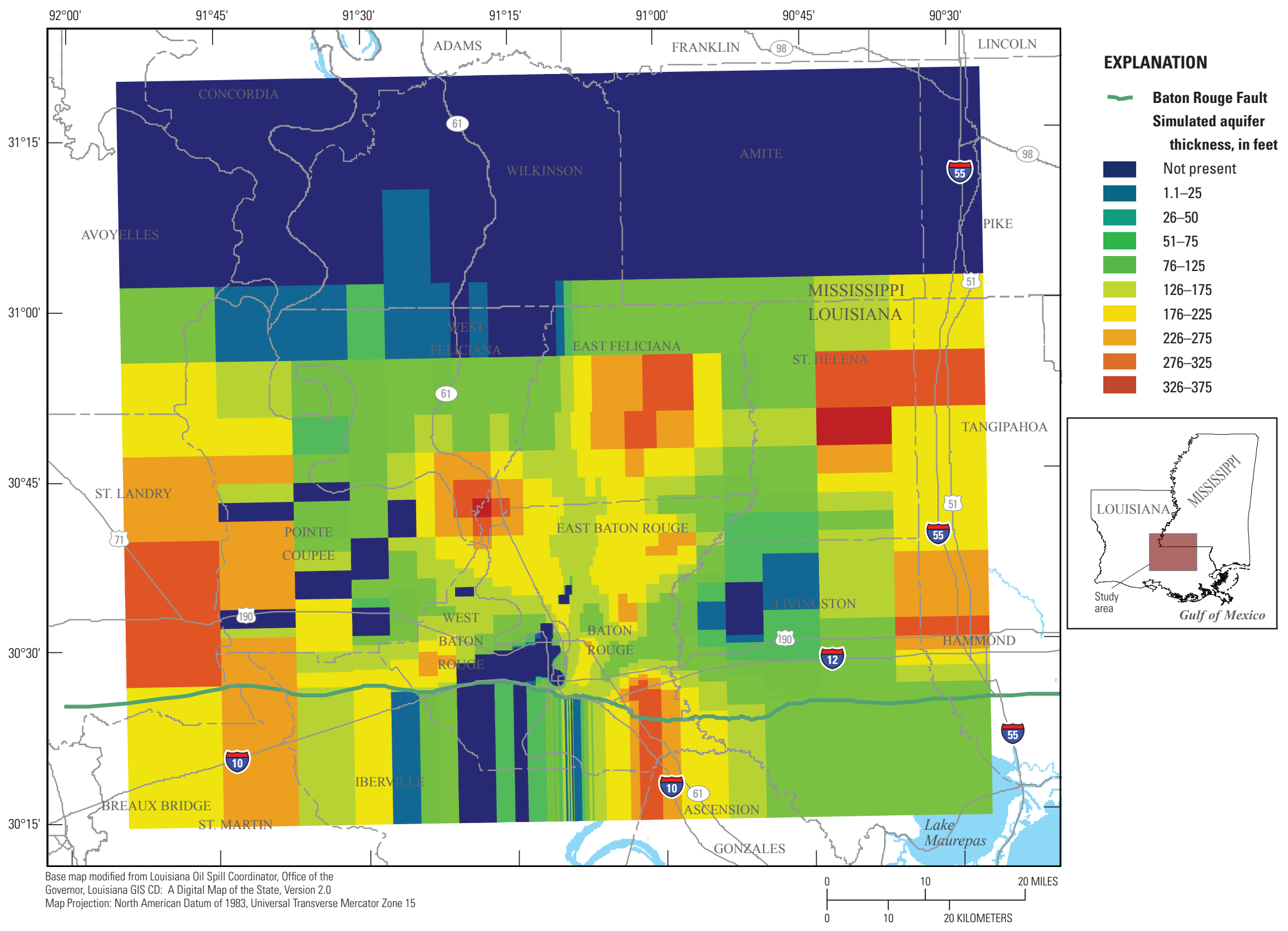




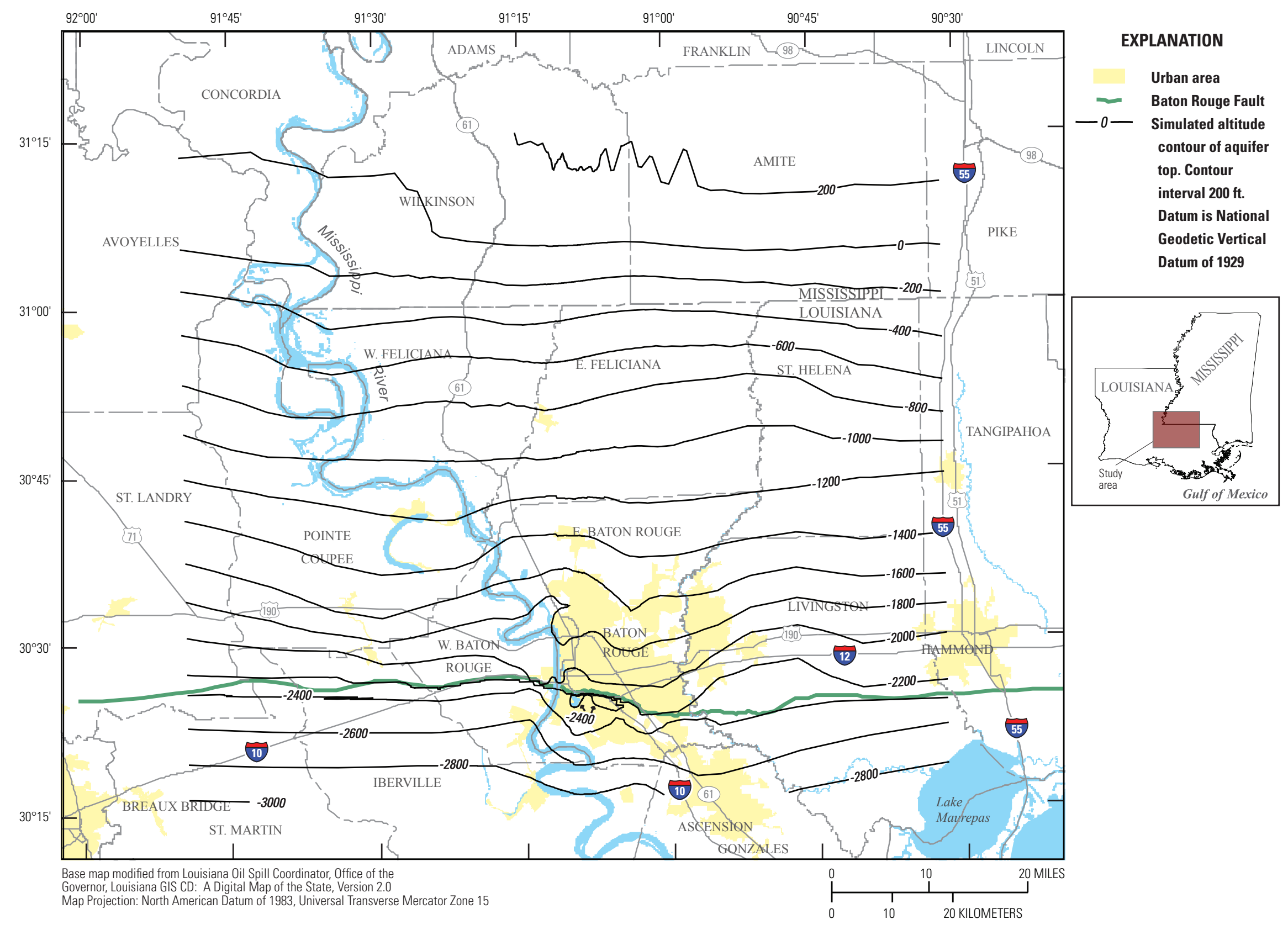

Figure 5. Map showing simulated altitude of the top of the "2,000-foot" sand of the Baton Rouge area in southeastern Louisiana and southwestern Mississippi. 


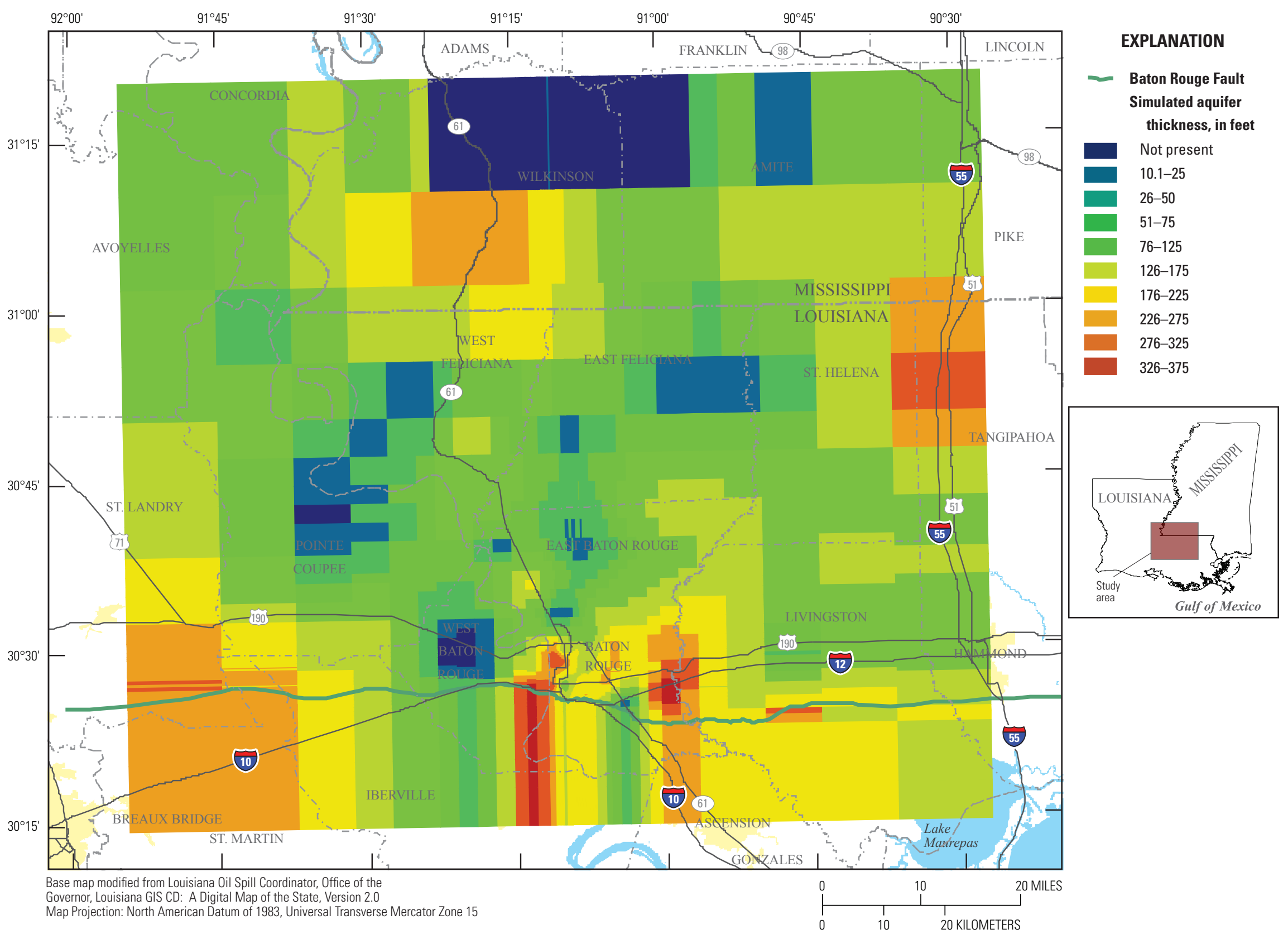




\section{Occurrence and Movement of Saltwater}

Groundwater investigations conducted during the 1960 s identified a freshwater-saltwater interface located near the Baton Rouge Fault (Morgan and Winner, 1964; Rollo, 1969). Prior to groundwater development in the 1940s, freshwater flowed from recharge areas in Mississippi southward toward the fault, then upward to where it discharged at springs. This groundwater-flow pattern caused aquifers north of the fault to generally contain freshwater whereas they may contain saltwater south of the fault. Exceptions exist because freshwater is also found in some areas south of the Baton Rouge fault, such as West Baton Rouge Parish, where both the "1,500-foot" sand and "2,000-foot" sand contain freshwater areas. In the Baton Rouge area, the base of freshwater is between about 1,100 and 2,600 ft deeper on the north side of the fault than it is on the south side of the fault. The altitude of the base of freshwater ranges between about $-1,500 \mathrm{ft}$ and $-3,500 \mathrm{ft}$ north of the fault, and between -200 and $-1,000 \mathrm{ft}$ south of the fault (Smoot, 1988; Griffith, 2003). Aquifer tests conducted across the fault in the vicinity of Baton Rouge have indicated that the fault acts as a leaky barrier that impedes groundwater flow (Whiteman, 1979).

Large groundwater withdrawals north of the fault in Baton Rouge, primarily for public supply and industrial use, have lowered water levels and created gradients conducive to the movement of saltwater from the south side of the fault into previously freshwater areas north of the fault (Whiteman, 1979; Tomaszewski, 1996). Except in the deeper "2,800-foot" sand and Catahoula aquifers, most saltwater currently north of the fault moved in response to the groundwater withdrawals in the Baton Rouge area. If groundwater withdrawals in the Baton Rouge area continue at rates similar to the historical rates, saltwater encroachment will probably continue to occur (Tomaszewski, 1996).

Based on historical chloride-concentration data collected through 2005, saltwater and water containing chloride concentrations above background levels (10 $\mathrm{mg} / \mathrm{L}$ or less) have been detected in all aquifers in the Baton Rouge area except the "800-foot" sand and "1,700-foot" sand (Lovelace, 2007). Analyses of chloride-concentration measurements collected from wells prior to 1992 indicated that saltwater encroachment had occurred in the " 600 -foot" sand, " 800 foot" sand, "1,000-foot" sand, "1,500-foot" sand, and "2,000foot" sand (Morgan and Winner, 1964; Whiteman, 1979; Tomaszewski, 1996). Chloride concentration data collected from 1993 to 2003 indicated that chloride concentrations increased in the "1,000-foot" sand, "1,200-foot" sand, "1,500-foot" sand, "2,000-foot" sand, "2,400-foot" sand, and "2,800-foot" sand (Lovelace, 2007). Chloride concentrations measured during 2004 to 2005 exceeded background levels in one or more water samples from wells in East and West Baton Rouge Parishes north of the fault screened in the " 600 -foot" sand, "1,000-foot" sand, "1,200-foot" sand, "1,500-foot" sand, "1,700-foot" sand, "2,000-foot" sand, "2,400-foot" sand, and "2,800-foot" sand. Comparison of the 2004-5 data with historical data indicated that chloride concentrations north of the Baton Rouge Fault were increasing in all of those aquifers except the "1,700-foot" sand (Lovelace, 2007). Within the "2,000-foot" sand, chloride concentrations of about $3,500 \mathrm{mg} / \mathrm{L}$ have been measured $3 \mathrm{mi}$ east of the Mississippi River and about 500 feet north of the Baton Rouge Fault in observation well EB-781.

\section{Hydrogeologic Framework}

A three-dimensional hydrogeologic framework was constructed to delineate the extents and thicknesses of aquifers and confining units in the study area. The hydrogeologic framework represents the entire sequence of aquifers and confining units in the Southern Hills regional aquifer system above the Catahoula-equivalent aquifer system (table 2). The Catahoula-equivalent aquifer system was omitted from the framework because in the study area it contains mostly saltwater and is little used, and few data from stratigraphic control wells (fig. 1) were available to delineate the extent and thickness of the aquifers in the system. The hydrogeologic framework defines the top altitudes and thicknesses of the hydrogeologic units in the groundwater model documented in this report. Although the groundwater model was primarily developed to address concerns about declining groundwater levels in the "1,500-foot" sand and "2,000-foot" sand and saltwater encroachment in the "2,000-foot" sand, simulating groundwater flow in overlying and underlying aquifers improved the simulation of water-levels in the "1,500-foot" sand and "2,000-foot" sand aquifers.

The top of the hydrogeologic framework is the ground surface and the base is the bottom of the " 2,800 -foot" sand. The aquifers and confining units are represented by 22 layers, numbered from the top toward the bottom (table 1). Layers 1, $3,5,7,9-18,20$, and 22 make up the aquifer layers. Layers $2,4,6,8,19$, and 21 make up confining units that separate the aquifer layers. Layers 1 and 3 represent multiple aquifers that have similar hydraulic characteristics and are likely interconnected. Layer 1 represents the Mississippi River alluvial aquifer, shallow sands, upland terrace aquifer, and the " 400 -foot" sand, "600-foot" sand, and " 800 -foot" sand. Layer 3 includes the "1,000-foot" sand and " 1,200 -foot" sand. The "2,000-foot" sand is represented by 10 layers numbered 9 through 18.

The location and thickness of aquifer and confining-unit layers in the hydrogeologic framework were specified on the basis of lithologic contacts at 192 stratigraphic control wells (fig. 1) and the previous work of Griffith (2003). About 3,200 lithologic contacts were interpreted from borehole resistivity, spontaneous potential, nuclear, and (or) drillers' lithologic logs on file at the USGS office in Baton Rouge for the stratigraphic control wells. Generally, aquifers and confining units less than $10 \mathrm{ft}$ thick were not represented by discrete layers in the hydrogeologic framework. 
Raster arrays of the top altitudes and thicknesses of all hydrogeologic framework layers were constructed with the VIEWLOG interpolation tool (Viewlog Systems, 2004). Hydrogeologic contacts interpreted from logs outside the study area were used to specify the hydrogeologic unit altitudes along the boundary of the study area. The hydrogeologic unit top altitudes interpolated with VIEWLOG were manually smoothed in areas where data were unavailable (generally near the margin of the study area). Contour maps illustrate the top altitudes and thicknesses of the hydrogeologic framework layers that represent the " 1,500 -foot" sand and the " 2,000 foot" sand (figs. 3, 4, 5, and 6).

The location and correlation of hydrogeologic units near the Baton Rouge Fault in the study area are uncertain (Griffith, 2003), and the apparent displacement of units may be due to differences in sediment deposition on either side of the fault (Smith, 1979). By using previous reports (Durham and Peeples, 1956; Murray, 1961; Winner and others, 1968; Rollo, 1969; Whiteman, 1979; Smith, 1979; Hanor, 1982; Smoot, 1988; McCulloh, 1991; Griffith, 2003, 2006) and the lithologic contacts, separate representations of hydrogeologic unit layer top altitudes and thicknesses were generated for areas north and south of the Baton Rouge Fault. The separate north and south representations for each layer were linked at the fault to form a single representation for each layer so that differences in layer top altitudes across the Baton Rouge Fault represent the vertical fault displacement (fig. 7).

\section{Groundwater Withdrawals}

Withdrawals from 605 wells in Louisiana for the period of 1940 to 2007 were compiled from the digital databases and paper records of the USGS and the Commission. Most of these withdrawal records were reported by personnel at public supply and industrial facilities. Withdrawal rates for wells or facilities inventoried on a 5-year basis from 1960 to 2005 were obtained from USGS water-use records. Sporadic annual withdrawal data from 1940 to 1975 for some facilities in the Baton Rouge area also were obtained from USGS water-use records. Annual withdrawal rates from wells in East and West Baton Rouge, East and West Feliciana, and Pointe Coupee Parishes from 1975 to 2007 were obtained from the Commission water-use database. Annual withdrawal rates from about 1988 to 2007 for facilities that withdraw an average of $1 \mathrm{Mgal} / \mathrm{d}$ or greater and are located in other parishes in the study area were obtained from USGS wateruse records. Groundwater withdrawals from all aquifers in the study area averaged $168.22 \mathrm{Mgal} / \mathrm{d}$ during 2007.

Where only facility-specific withdrawals were available, well-specific rates were estimated by disaggregating the total withdrawal rate reported for the facility. Generally the disaggregated well-specific withdrawal rates were estimated by evenly distributing the withdrawals reported for each facility among the active wells at the respective facility.

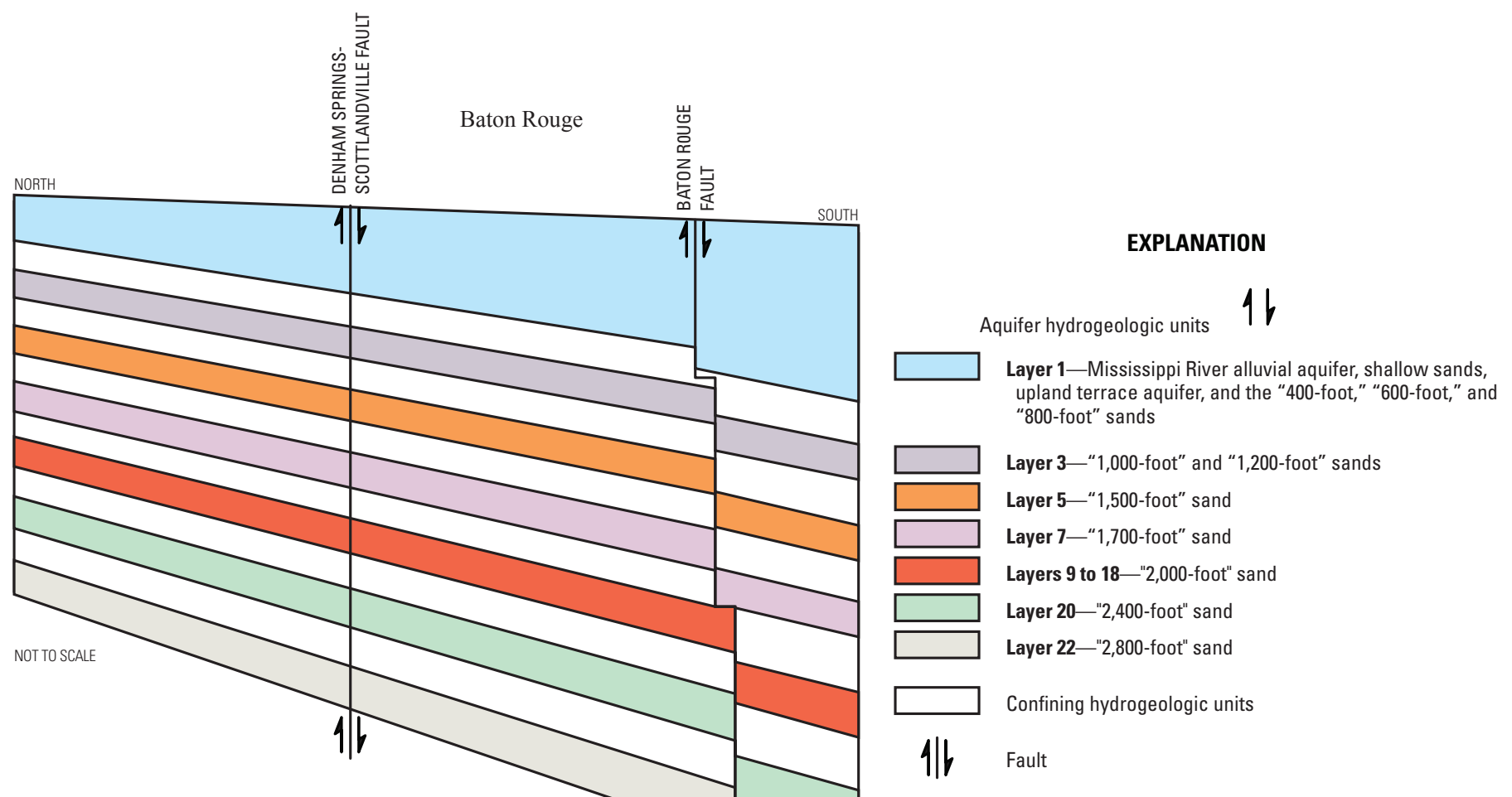

Figure 7. Conceptual offset of hydrogeologic units at faults in the Baton Rouge area, southeastern Louisiana. 
Well registration, construction, and plugging or abandonment data from USGS, DOTD, Commission, and Louisiana

Department of Natural Resources (DNR) databases were used to determine when specific wells were in use at the facilities where facility-specific withdrawals were reported. For some wells with intermittent data, annual withdrawals were estimated or interpolated to complete their pumpage records. In some cases, facilities were contacted to verify pumping rates and well activity during different periods.

Well-construction data including the borehole, screen, and casing diameters; screen intervals; pump depth; location; and land-surface altitude were obtained from USGS and State databases. Missing or inadequate information was estimated or adjusted by using ancillary information from topographic maps, well logs, the specifications of other nearby wells or wells with identical ownership, well schedules, and thickness data from the hydrogeologic framework. Some wells with inadequate well-construction information and probable withdrawal rates less than $0.01 \mathrm{Mgal} / \mathrm{d}$ were omitted. Wells with screen-interval records corresponding to confining-unit intervals in the hydrogeologic framework were assumed to be screened in aquifers and were assigned to the appropriate adjacent sand layer.

A graph of the withdrawals from the " 400 -foot," "600foot," "800-foot," "1,000-foot," "1,200-foot," "1,500-foot," "1,700-foot," "2,000-foot," "2,400-foot," and "2,800-foot" sands, collectively referred to herein as the "Baton Rouge sands," illustrates both increased total withdrawals and the withdrawal from deeper aquifers through time (fig. 8). Until the early 1950s, groundwater withdrawals were principally from the " 400 -foot" sand and the " 600 -foot" sand. Since that time, deeper aquifers such as the "1,200-foot" sand, "1,500-foot" sand, "2,000-foot" sand, "2,400-foot" sand, and "2,800-foot" sand have increasingly supplied most groundwater in the Baton Rouge area. In 2007, an estimated $180 \mathrm{Mgal} / \mathrm{d}$ were withdrawn from the Baton Rouge sands, including $23.7 \mathrm{Mgal} / \mathrm{d}$ from the "1,500-foot" sand and 25.3 Mgal/d from the "2,000-foot" sand. Withdrawals from other aquifers within the study area were 37.7 Mgal/d. Industrial withdrawals, primarily in the Baton Rouge industrial district, accounted for $16.6 \mathrm{Mgal} / \mathrm{d}$, or 66 percent of the total water withdrawn from the "2,000-foot" sand during 2007. Figure 9 shows the average daily withdrawal rate during 2007 at wells screened in the "2,000-foot" sand and located at or near the Baton Rouge industrial district.

\section{Simulation of Groundwater Flow and Movement of Saltwater}

The modeling strategy was to initially construct a constant-density groundwater-flow model and calibrate the groundwater-flow model parameters to observed water levels throughout the aquifer system. Subsequently, the simulation of saltwater transport with a variable-density version of the groundwater-flow model was accomplished. Calibration of simulated concentrations to chloride concentrations observed in the Baton Rouge area required minor modification of some flow-model parameters and estimation of parameters that represented effective porosity and aquifer dispersivities. The highest observed chloride concentration north of the Baton Rouge Fault within the "2,000-foot" sand has been 3,500 $\mathrm{mg} / \mathrm{L}$, implying that groundwater at that location has a density of about 62.71 pounds per cubic foot $\left(\mathrm{lb} / \mathrm{ft}^{3}\right)$, which is about 0.45 percent greater than freshwater. Although the density of localized areas of brackish to saline groundwater (chloride concentration from 1,000 to $10,000 \mathrm{mg} / \mathrm{L}$ ) may sufficiently contrast with adjacent fresher groundwater to affect flow in some areas, such as adjacent to the Baton Rouge Fault, density contrasts over larger areas are not thought to substantially affect regional groundwater flow. Because the constantdensity groundwater-flow code MODFLOW-2005 (Harbaugh, 2005) can apportion specified pumpage withdrawals among multiple aquifers penetrated by a single well, which is important for simulating transient groundwater flow in the Baton Rouge area, it was used during the groundwater-flow model calibration process. After the groundwater-flow model had been calibrated, the optimal set of flow parameters and computed well fluxes were imported into the variable-density finite-difference code SEAWAT-2000 (Langevin and others, 2003), hereinafter referred to as SEAWAT, which enabled simulation of saltwater transport.

High concentrations of salt (sodium chloride) increase groundwater density and can affect the patterns and rates of groundwater flow if the density varies spatially. Although most chloride concentrations in the "2,000-foot" sand north of the Baton Rouge Fault are less than several hundred milligrams per liter, which is too low to substantially increase groundwater density, concentrations up to $3,500 \mathrm{mg} / \mathrm{L}$ near the north side of the fault have been observed and are likely higher in observed locations closer to the source of the salt. The effect of density contrasts on groundwater flow was simulated with the variable-density finite-difference code SEAWAT (Langevin and others, 2003), which integrates MODFLOW-2000 (Harbaugh and others, 2000) with MT3DMS (Zheng and Wang, 1999), a code that simulates solute transport. Because chloride is a conservative solute, chemical reactions were not simulated in the SEAWAT transport model. Temperature gradients within the Southern Hills aquifer system north of the Baton Rouge Fault are not substantial and are not known to affect groundwater flow within the "1,500-foot" sand and "2,000-foot" sand. The groundwater system was therefore modeled as isothermal, and temperature effects on groundwater density and viscosity were not simulated.

The model-inputs for SEAWAT and MODFLOW-2005 are generally similar, but the multi-node well package, MNW2 (Konikow and others, 2009), was not available with SEAWAT. Because the apportionment of withdrawals among aquifers from wells tapping multiple aquifers was important for groundwater-flow model calibration, the MODFLOW-2005 code was used during the parameter estimation process. After the flow-model parameters had been optimized, an equivalent WEL package (Harbaugh and others, 2000) 


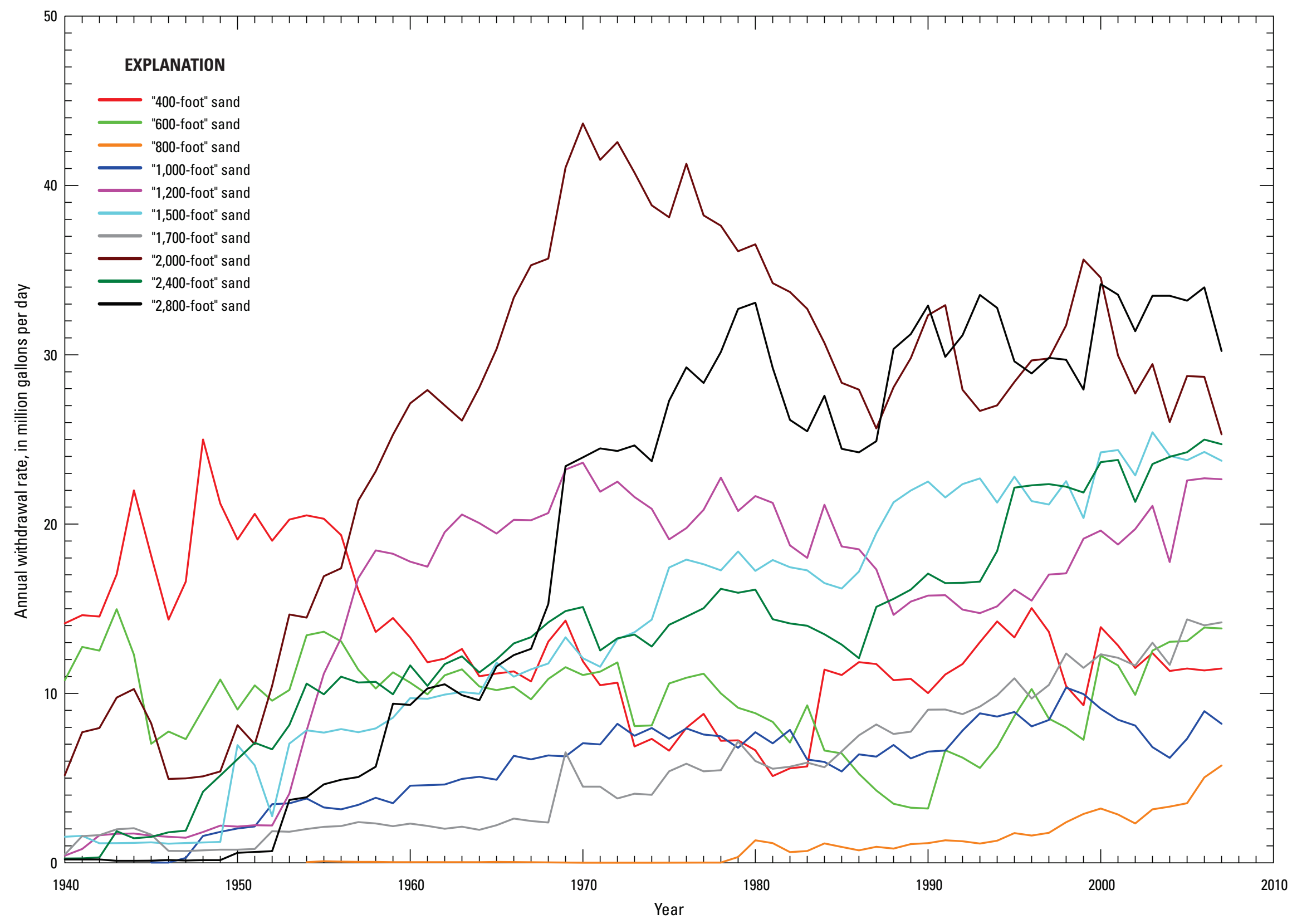

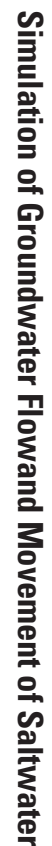

Figure 8. Graph showing estimated withdrawals from the Baton Rouge sands, 1940-2007 


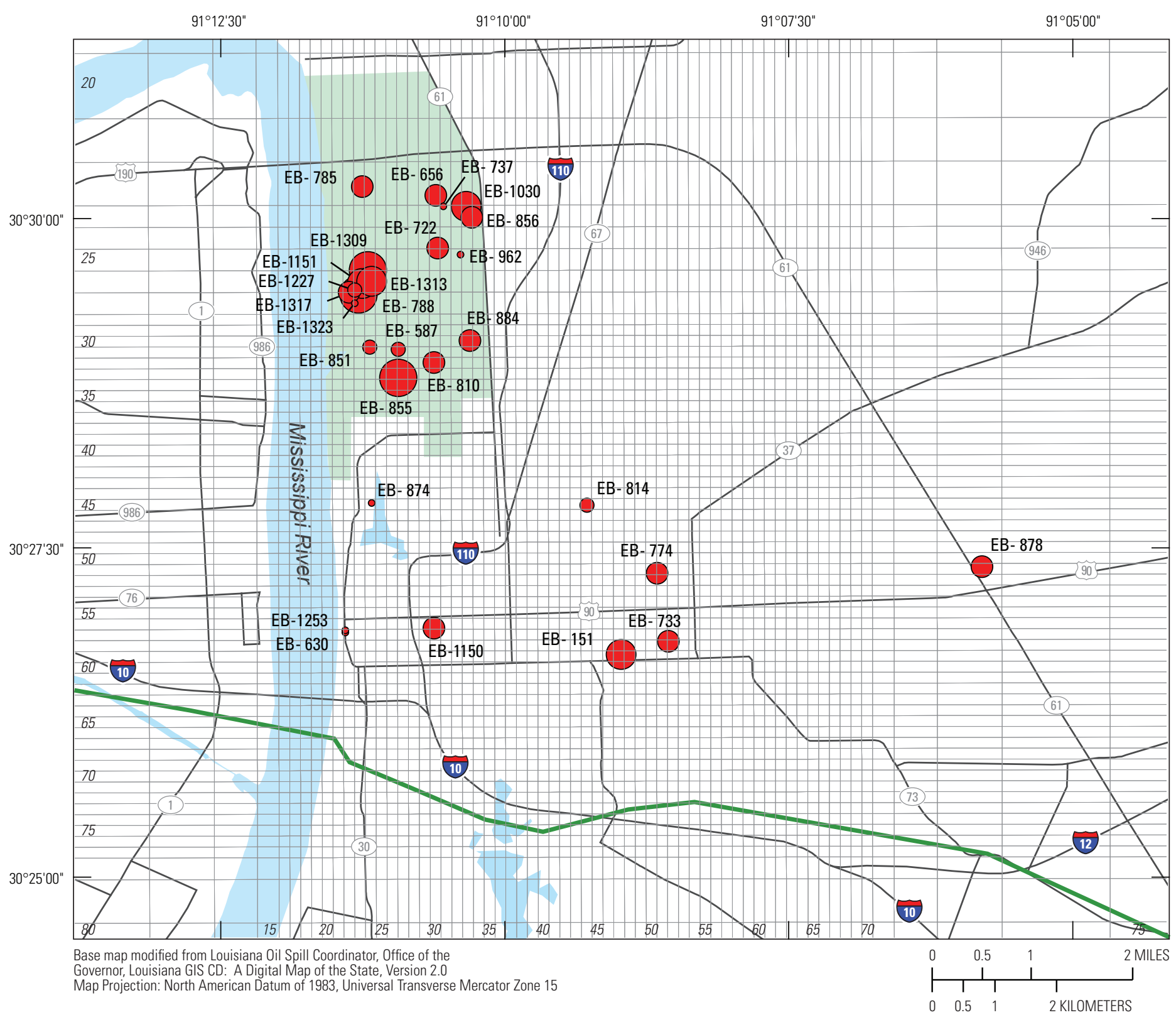

\section{EXPLANATION}

Industrial district
$-\quad$ Baton Rouge Fault

70 Model grid row or

column number

Withdrawal rate in

2007, in million

gallons per day,

and well number

- $\quad 0-0.15$

○ $\quad 0.15-0.35$

0.35-1.0

1.0-1.5

$11.5-3.0$

EB-1030

Figure 9. Average daily withdrawal rate during 2007 at wells screened in the "2,000-foot" sand of the Baton Rouge area and located at or near the Baton Rouge industrial district in southeastern Louisiana. 
input was generated with MNW2 by using the parameter values optimized for the MODFLOW-2005 simulation. This computed WEL Package input was subsequently used to specify layer-variable groundwater fluxes for each withdrawal well in the SEAWAT simulation.

\section{Conceptual Model for Saltwater Transport}

Groundwater north of the Baton Rouge Fault is assumed to have been fresh prior to groundwater development. Groundwater entering the model domain in areas north of the Baton Rouge Fault is considered "fresh" with a zero salt concentration. Because sediments south of the Baton Rouge Fault are displaced downward, the source of saltwater south of the Baton Rouge Fault is likely within the "1,700-foot" sand, where its altitude is similar to that of the "2,000-foot" sand north of the fault. Although chloride concentrations south of the Baton Rouge Fault have been observed to vary spatially and some areas of freshwater are known to occur, a simple representation of the saltwater source is preferred to model transport north of the fault. This source was specified within the finitedifference cells adjacent to the south side of the fault that connect to the "2,000-foot" sand on the north side of the fault. As groundwater withdrawals cause aquifer water levels to decline north of the Baton Rouge Fault, higher pressure saltwater south of the fault seeps northward across the hydraulically resistive fault.

\section{Equations of Groundwater Flow and Transport}

Whereas MODFLOW-2005 solves the constant-density groundwater-flow equation (Harbaugh, 2005), the SEAWAT (Langevin and others, 2003) code iteratively solves equations that represent variable-density groundwater flow and advective-dispersive mass transport. These equations are succinctly presented below, and the interested reader may refer to the referenced model-code documentation for further details.

Groundwater systems without significant chemical reactions or temperature gradients are governed by equations for variable-density flow:

$$
-\nabla \cdot(\rho \vec{q})+\bar{\rho} q_{s}=\rho S_{p} \frac{\partial P}{\partial t}+\theta \frac{\partial \rho}{\partial C} \frac{\partial C}{\partial t}
$$

and mass transport:

$$
\frac{\partial C}{\partial t}=\nabla \cdot(D \nabla C)-\nabla \cdot\left(\frac{\vec{q}}{\theta} C\right)-\frac{q_{S}}{\theta} C_{S}
$$

where

$\begin{array}{ll}\nabla & \text { is the gradient operator, } \\ \rho & \text { is fluid density }\left[\mathrm{ML}^{-3}\right], \\ \bar{q} & \text { is specific discharge }\left[\mathrm{LT}^{-1}\right], \\ \bar{\rho} & \text { is source or sink fluid density }\left[\mathrm{ML}^{-3}\right], \\ q_{S} & \text { is flow rate per unit volume representing } \\ & \quad \text { sources or sinks }\left[\mathrm{T}^{-1}\right], \\ S_{p} & \text { is specific storage in pressure terms }\left[\mathrm{M}^{-1} \mathrm{LT}^{2}\right], \\ P & \text { is fluid pressure }\left[\mathrm{ML}^{-1} \mathrm{~T}^{-2}\right], \\ t & \text { is time }[\mathrm{T}], \\ \theta & \text { is effective porosity, } \\ C & \text { is solute concentration }\left[\mathrm{ML}^{-3}\right], \\ D & \text { is the dispersion coefficient }\left[\mathrm{L}^{2} \mathrm{~T}^{-1}\right], \text { and } \\ C_{c} & \text { is source or sink solute concentration }\left[\mathrm{ML}^{-3}\right] .\end{array}$

These groundwater flow and transport equations are coupled by the specific discharge ( $\overrightarrow{\mathrm{q}}$ ) and concentration (C) terms. The dependence of fluid density on concentration can be approximated by a linear equation of state:

$$
\rho=\rho_{f}+\frac{\partial \rho}{\partial C} C
$$

where $\rho_{f}$ is the density of freshwater. The SEAWAT (Langevin and others, 2003) code iteratively solves finite-difference versions of these variable-density flow and mass transport equations for every transport time step, thereby coupling the flow and transport equations. Because this solute-transport problem was advection-dominated, the advection-dispersion (equation 2) was numerically solved with the third-order total-variation-diminishing (TVD) scheme to reduce numerical dispersion (Zheng and Wang, 1999).

\section{Spatial Discretization}

The three-dimensional finite-difference groundwater model grid (fig. 10) was designed with variable grid-cell spacing to (1) provide sufficient spatial resolution in a $25-\mathrm{mi}^{2}$ area (the detailed model area) where significant saltwater migration either has occurred or could occur in the future (fig. 11), (2) locate model boundaries sufficiently far from the detailed model area to minimize the effects of boundary conditions on simulated heads in the area, and (3) limit execution times to enable numerous model simulations to be conducted during calibration through parameter estimation. The total area encompassed by the model domain is $6,529.23 \mathrm{mi}^{2}$ and contains 158,950 active finite difference cells. The areas encompassed by the finite-difference cells range from $2.5 \times 10^{5} \mathrm{ft}^{2}(5.74$ acres) in the detailed model area to a maximum of $3 \times 10^{9} \mathrm{ft}^{2}(68,870$ acres $)$ at the northwest corner of the model domain.

The variable grid spacing creates a large finite-differencecell aspect ratio, or differences in the north-south versus eastwest dimensions, in some areas of the model grid. Although numerical inaccuracies can occur in such areas (de Marsily, 1986), they are located in areas of the model grid where high computational accuracy is not required. 


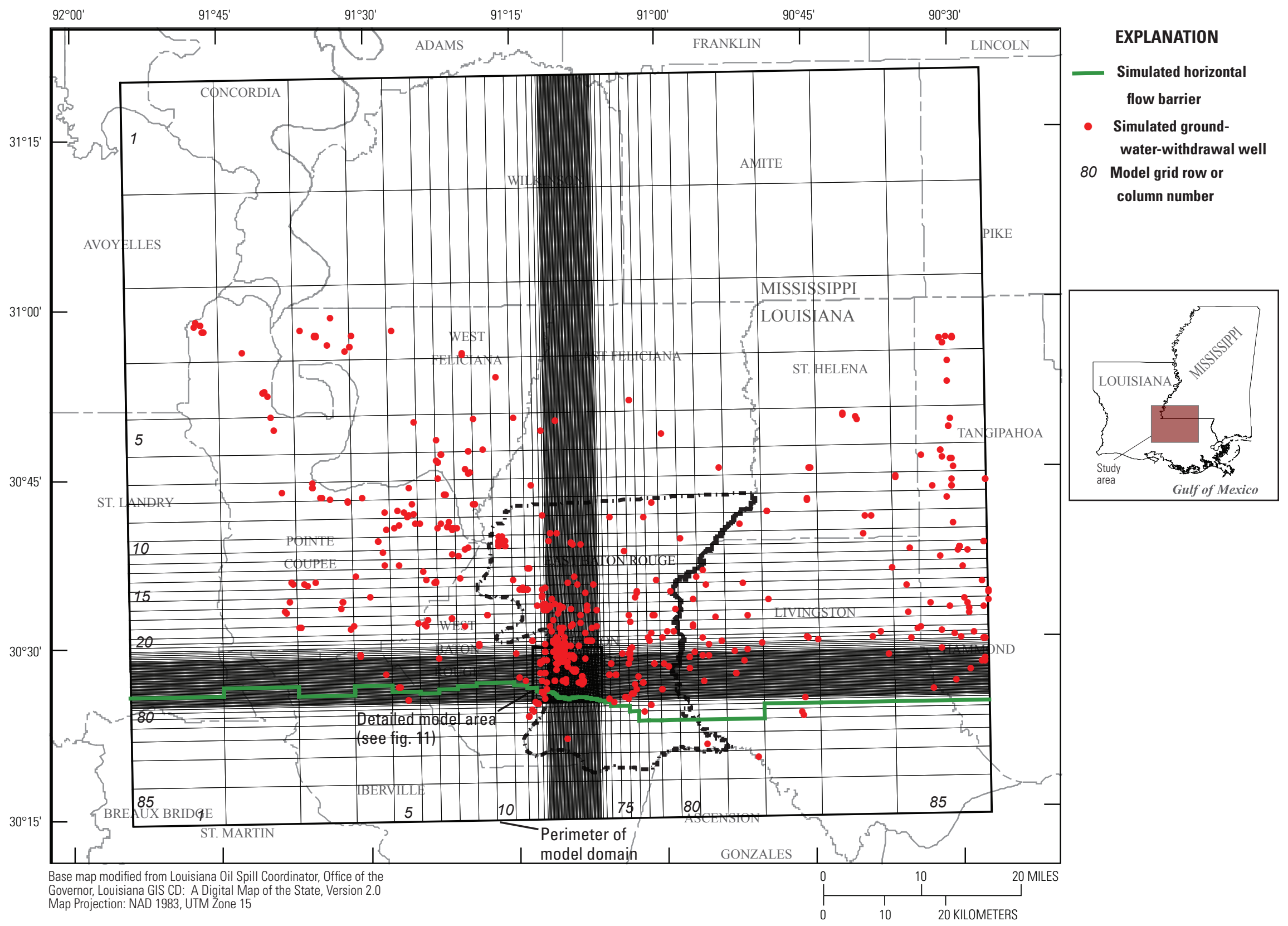

Figure 10. Map showing the model finite-difference grid and locations of the horizontal flow barrier in the "2,000-foot" sand of the Baton Rouge area and simulated groundwater-withdrawal wells in southeastern Louisiana and southwestern Mississippi. 


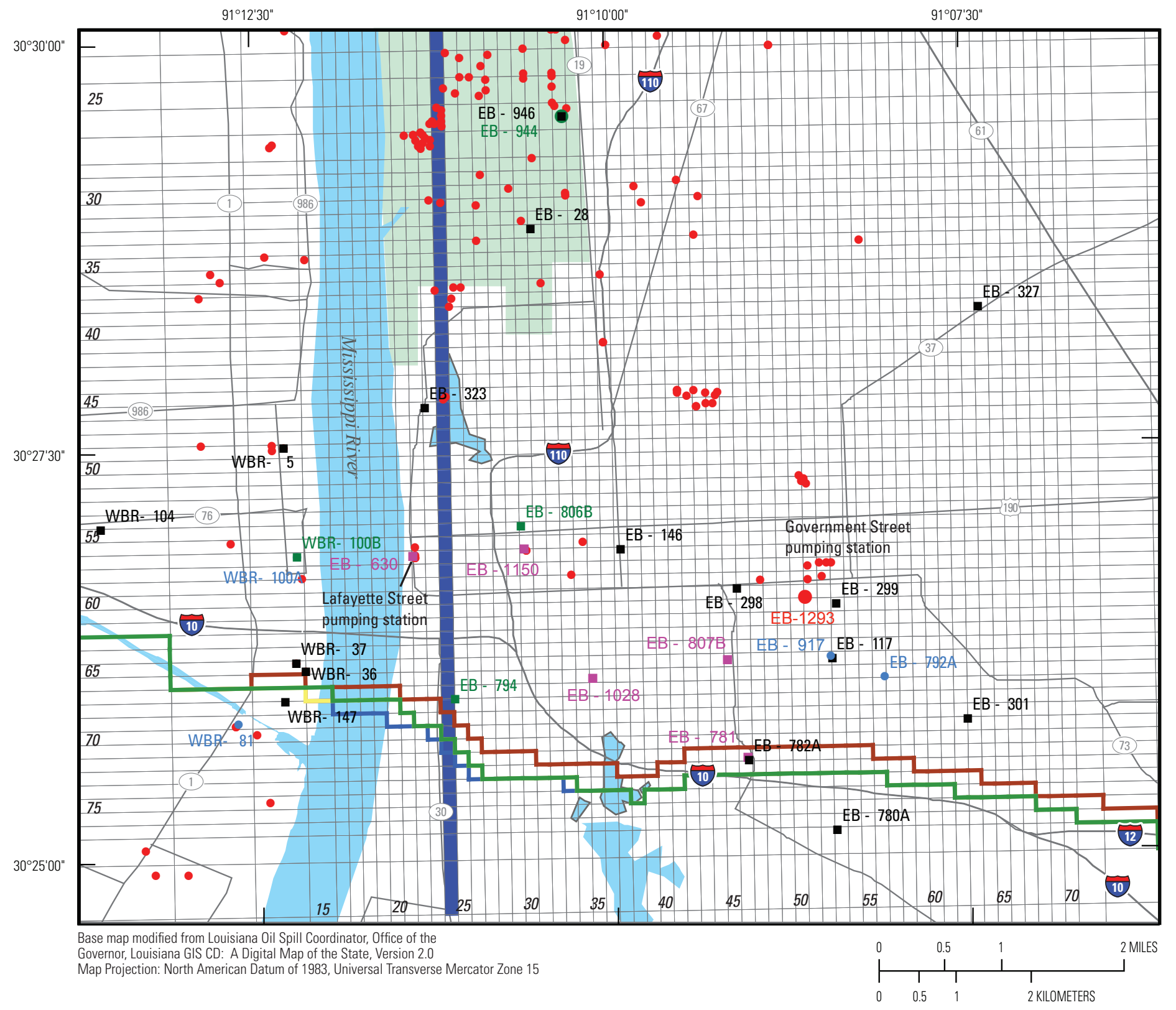

EXPLANATION

Industrial district

Horizontal flow

barrier, by aquifer

"1,000/1,200-foot" sand

- "1,500-foot" sand

"2,000-foot" sand

"2,400/2,800-foot" sand

Location of cross-

section shown

in figure 12

70 Model grid row or column number

- Groundwater-withdrawal well

- Chloride concentration

EB - 630 observation well and well name

Water-level observation well and well name, by aquifer

- "1,000/1,200-foot" sands EB-146

"1,700-foot" sand WBR-8

- 2,400-foot" sand EB-794

"2,800-foot" sand EB-944

"Connector well"

EB-1293 screened in the "800 foot" and "1,500-foot" sand

Figure 11. Map showing the finite-difference grid and locations of horizontal flow barriers, simulated groundwater-withdrawal wells, and water-level observation wells in the "1,000-foot," "1,200-foot," "1,700-foot," “2,400-foot," and “2,800-foot” sands of the Baton Rouge area in the detailed model area in southeastern Louisiana. 
The model grid consists of 22 variable-thickness layers, each of which is a rectangular array containing 85 rows and 85 columns of finite-difference cells. For a subset of the model grid, 50 rows by 55 columns, horizontal grid spacing of $500 \mathrm{ft}$, and vertical layer spacing of about $20 \mathrm{ft}$ within the " 2,000 foot" sand were specified within the $25-\mathrm{mi}^{2}$ detailed model area based on preliminary simulations along two-dimensional cross-sections throughout the Baton Rouge area. Transport of saltwater was only simulated within the detailed model area to limit model execution times.

The altitude of the top of each model layer on the north side of the Baton Rouge Fault was assigned the altitude of the top of hydrogeologic framework unit represented by the layer (table 2). South of the Baton Rouge Fault, the altitudes of the top of each finite-difference layer do not correspond to the tops of hydrogeologic framework units and are constant along columns of finite-difference cells (that is, in the northsouth direction). This geometry facilitated simulation of flow across the Baton Rouge Fault and is explained in further detail in the "Internal Flow Package" section. The north-south cross-sectional view of the model grid (fig. 12) along column 24 illustrates the variable thickness and "pinching out" of hydrogeologic units north of the Baton Rouge Fault, the offset of hydrogeologic units at the fault, and the discordance between hydrogeologic units and finite-difference cells south of the fault.

In comparison to numerical solution of the transient groundwater-flow equation, numerical solution of the transient solute-transport equation is computationally intensive. It is therefore generally desirable to limit the size of the numerical solute-transport problem when possible. Because simulation of saltwater encroachment is needed in only a small portion of the flow-model domain, a subset of the groundwater-flow model grid was identified for simulation of solute transport. This solute-transport domain is the previously described "detailed model area" that has a 500 -ft cell spacing (fig. 11). Within this area, the solute transport equation was numerically solved in all model layers but was calibrated only for model layers 9 through 18 , which correspond to the "2,000-foot" sand on the north side of the Baton Rouge Fault.

\section{Internal Flow Package}

Offsets of hydrogeologic units at the Baton Rouge Fault may enable flow from stratigraphically younger hydrogeologic units south of the fault into stratigraphically older and horizontally juxtaposed units north of the fault. This flow between hydrogeologic units was simulated by using the Hydrogeologic-Unit Flow Package (HUF) (Anderman and Hill, 2000), which represents the thickness of hydrogeologic units independently from that of the model finite-difference-grid-cell layers and calculates storage and intercell conductance terms for each cell from the hydraulic property distributions assigned to individual hydrogeologic units present within that cell. In this model, the altitudes of the finite-difference layers correspond to the tops and bottoms of the aquifers and intervening confining units defined in the hydrogeologic framework only for the portion of the model domain north of the Baton Rouge Fault (fig. 12). South of the Baton Rouge Fault, the finite-differencelayer altitudes within each model-grid column are "flat," with altitudes equal to those at the simulated fault location. The finite-difference layers do not correspond to specific hydrogeologic units south of the Baton Rouge Fault. Because of this lack of correspondence, different hydrogeologic units are contained within each finite-difference layer on the north versus south sides of the fault, which allows simulated flow and transport within finite-difference layers between different aquifers that are horizontally juxtaposed at the fault. For example, the " 1,700 -foot" sand on the south side of the fault may be connected to the "2,000-foot" sand on the north side of the fault along some portions of the fault. Because of accuracy limitations in the digital representation of the hydrogeologic framework near the fault, this connection was initially not adequately represented within model finite-difference layers 9 through 18 where saltwater is thought to cross the fault. To compensate for this limitation, a portion of the hydrogeologic unit layer which generally represents the confining unit above the "2,000-foot" sand was assigned to the overlying "1,700foot" sand in cells on the south side of the Baton Rouge fault between columns 38 and 48 (fig. 11).

\section{Horizontal Flow Barriers}

The resistance to groundwater flow at the Baton Rouge Fault as a consequence of sediment deformation and displacement of sedimentary layers was simulated with horizontal flow barriers (HFB) (Hsieh and Freckleton, 1993), which were specified along the vertical faces of cells closest to the fault. The decrease of each HFB to the conductance between adjacent model cells is specified with a "hydraulic characteristic" that is dimensionally equivalent to the hydraulic conductivity of the fault zone (in the direction perpendicular to the fault plane) divided by the width of the fault zone. HFBs were defined for all model layers that simulated aquifers except model layer 1.

Because the Baton Rouge Fault plane dips to the south at 65 to 70 degrees, the fault dip was represented by offsetting the fault to the south in deeper framework layers. In layers 2 through 7 the fault is represented $500 \mathrm{ft}$ south of its surface location as indicated in figure 1 , whereas in layers 8 through 22 the fault is offset $1,000 \mathrm{ft}$ south of its surface location.

\section{Temporal Discretization}

Because groundwater withdrawals from the Southern Hills aquifer system were relatively minor prior to about 1940, a single steady-state stress period was used to simulate predevelopment conditions in the groundwater-flow system (table 3). Sixty-eight annual stress periods simulated the time from January 1, 1940, through December 31, 2007. 


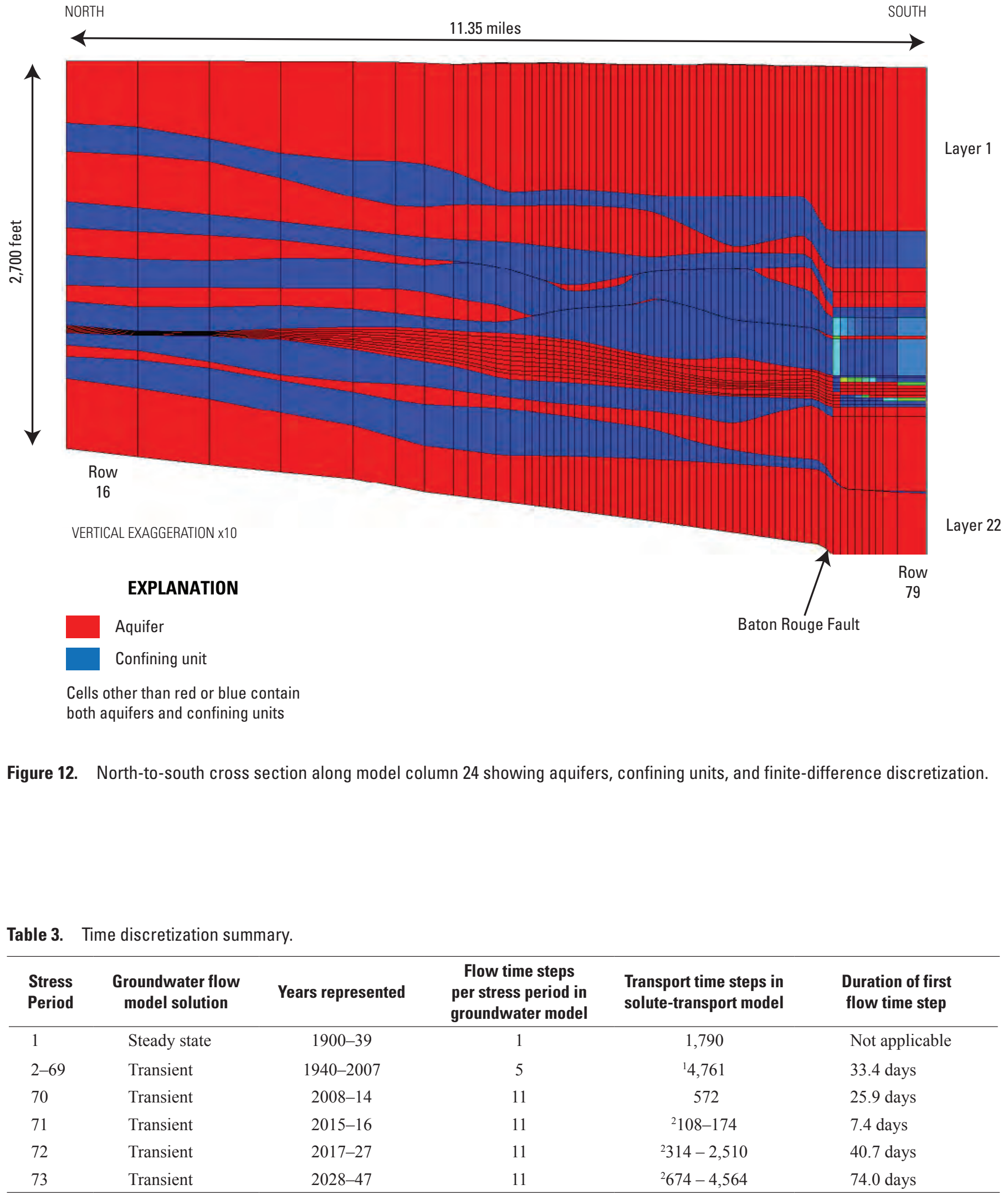

${ }^{1}$ Total number of transport time steps simulating 1940 through 2007.

${ }^{2}$ Number of transport time steps varied among scenarios 1 through 6 . 
Each stress period was discretized into five time steps that geometrically increase in duration by a factor of 1.4 , such that the first time step of each stress period simulated about 33 days. Hypothetical scenarios used four transient stress periods of various lengths that represented January 1, 2008, through December 31, 2047, each of which were discretized into 11 time steps that also geometrically increase in duration by a factor of 1.4. The geometric progression of increasing time-step length provided good temporal discretization for simulation of transient changes in groundwater levels. In the solute-transport simulations, flow time steps are further subdivided into transport time steps (table 3). The number of transport time steps was computed internally on the basis of the flow velocity to maintain numerical stability and varied with the specified effective porosity and boundary conditions, such as specified groundwater withdrawal rates. Smaller transport time steps are required as the flow velocity increases.

\section{Boundary Conditions}

Boundary conditions were specified at the boundaries of the groundwater-flow system and within the model domain where they simulate groundwater-withdrawal wells. Three types of boundary conditions were specified for the groundwaterflow model: no-flow, specified head, and head-dependent flux. Constant concentration boundaries were also specified at the lateral boundaries of the solute-transport model.

\section{No-Flow Boundaries}

The north, east, and west sides and the top 21 layers of the southern side of the groundwater-flow model domain (fig. 10) are located where negligible groundwater flow is presumed to enter or exit the model domain and were accordingly considered no-flow boundaries. The southernmost row of the lowest model layer (row 85, layer 22) contains a specified-head boundary. The model-domain perimeter was located sufficiently far from the Baton Rouge area to minimize any effect on simulated water levels in that area from possible inaccuracy of the no-flow boundary-condition specification. The bottom model boundary at the base of layer 22 is also no-flow and corresponds to the top of a confining unit located above the Catahoula Formation (table 2), which restricts vertical groundwater flow.

\section{Specified-Head Boundaries}

Water levels in the top model layer (layer 1), which represents the " 400 -foot" sand, " 600 -foot" sand, and " 800 -foot" sand, were specified with the Flow and Head Boundary (FHB) package (Leake and Lilly, 1997). Water-level distributions that represent the years 1944, 1980, 1984, 1990, 1998, 1999, and 2004 were constructed from existing data. Water levels for times between these years were linearly interpolated for each model cell in the top layer. Steady-state (predevelopment) water levels were specified at the 1944 levels and water levels for times after 2004 were specified at the 2004 levels.

Water-level maps were digitized from previous reports: predevelopment (1944) (Kuniansky, 1989), 1980 (Martin and Whiteman, 1985; Boswell and Arthur, 1988), 1984 (Boswell and Arthur, 1988; Kuniansky, 1989), and 1990 (Tomaszewski, 1996). The water-level map for 2004 was created by using water-level data collected by the USGS in cooperation with the Commission and DOTD. Water-level maps for 1998 and 1999 were created by modification of the 1990 and 2004 water-level maps using water-level data collected at selected wells during 1998 and 1999 to more accurately specify water levels near the Commission's "connector well," EB-1293 (fig. 11), which was installed in 1998 and screened in the "800-foot" sand and "1,500-foot" sand (Dial and Cardwell, 1999). Because little water-level change has occurred within the model domain in Mississippi, interpreted water levels in Mississippi during 1982 (Boswell and Arthur, 1988) were incorporated into all of the water-level maps used to specify transient water levels with the FHB package. Historic waterlevel observations were used to modify the predevelopment water-level map (Kuniansky, 1989) in some areas.

A specified-head boundary was defined for the southern boundary of the bottom model layer (row 85 , layer 22) to simulate groundwater underflow out of the model domain under predevelopment conditions. The water level specified for this boundary was estimated during the model calibration process.

\section{Head-Dependent Flux Boundaries}

The previously described groundwater withdrawals were simulated with the revised MNW2 package of MODFLOW (Konikow and others, 2009), which was used because the screen intervals of many withdrawal wells span multiple model layers. The MNW2 package computes a layer-bylayer distribution of withdrawal for each well based on the hydraulic conductivities and simulated water levels in each finite-difference cell connected to the simulated well-screen interval. For each annual stress period, the average daily withdrawal from each well was specified in cubic feet per day $\left(\mathrm{ft}^{3} / \mathrm{d}\right)$. In some wells, water may flow between model layers when the water level simulated in a connected finite-difference cell is less than that simulated in the well. The effects of turbulent-flow head losses near the well and flow through drilling-damaged formation, gravel pack, or the well screen were not simulated.

Groundwater withdrawals from wells screened in the top model layer (layer 1) corresponding to the Mississippi River alluvial aquifer, shallow sands, upland terrace aquifer, "400foot" sand, " 600 -foot" sand, and " 800 -foot" sand were not simulated because water levels in this layer were a specified boundary condition. One exception was the "connector well" (EB-1293) (Dial and Cardwell, 1999) near Baton Rouge Water Company's Government Street pumping station (fig. 11), where the water level for the top model layer (layer 1) 
was not specified. At this location, the MNW2 package was used to simulate flow through the "connector well," which has screens that intersect the "800-foot" sand (model layer 1 ) and the "1,500-foot" sand (model layer 5). Exclusion of layer 1 withdrawals, which accounted for about $49 \mathrm{Mgal} / \mathrm{d}$ in 2007, reduced the total withdrawals simulated in the model in 2007 to $169 \mathrm{Mgal} / \mathrm{d}$.

\section{Specified-Concentration Boundaries and Initial Conditions}

Model cells within the solute-transport domain adjacent to the south side of the Baton Rouge Fault were specified as constant-concentration boundaries and therefore retain the initially assigned concentration throughout the simulation. The saltwater source was simulated on the south side of the Baton Rouge Fault in model-grid columns 30 through 70 (fig. 11), corresponding to a 4-mile long region east of the Mississippi River. Within this region, the specified source concentration increases linearly from zero above model-grid layer 9 to a maximum at the base of layer 18. Model cells south of the Baton Rouge Fault and west of column 30 have zero concentration, corresponding to freshwater. Model-grid layers 1 through 8 and 19 through 22 were specified with zero initial concentration. The concentration of simulated water flowing from surrounding areas into the solute-transport domain is specified as zero, corresponding to freshwater.

North of the Baton Rouge Fault, initial concentrations were specified as zero (corresponding to freshwater), and variable concentrations were simulated within the "detailed model area." Simulated concentrations were normalized to the maximum specified source concentration, which was parameterized and estimated through model calibration to be $10,000 \mathrm{mg} / \mathrm{L}$ of chloride.

\section{Hydraulic-Property Distribution}

The simulated horizontal hydraulic conductivities $\left(\mathrm{K}_{\mathrm{h}}\right)$ within the hydrogeologic units that represent aquifers including the " 400 -foot" sand, "600-foot" sand, and " 800 -foot" sand; the "1,000-foot" sand and "1,200-foot" sand; the " 1,700 -foot" sand; the "2,400-foot" sand; and the "2,800-foot" sand were parameterized and estimated during model calibration. Areas within the "1,500-foot" sand and "1,700-foot" sand where those units "pinched out" were assigned the $\mathrm{K}_{\mathrm{h}}$ that was used for all of the confining unit layers. Because the specified thickness of each of these hydrogeologic units is spatially variable, simulated transmissivity is spatially variable within each hydrogeologic unit. Variability of $\mathrm{K}_{\mathrm{h}}$ within the " 1,500 foot" sand was simulated with three zones within which $\mathrm{K}_{\mathrm{h}}$ was uniform. The spatial variation of $\mathrm{K}_{\mathrm{h}}$ within the "2,000-foot" sand was interpolated by using pilot-points, as discussed in the following section. The vertical hydraulic conductivity $\left(\mathrm{K}_{\mathrm{v}}\right)$ for each of the hydrogeologic units representing the confining units (model layers 2, 4, 6, 8, 19, and 21 on the north side of the Baton Rouge Fault, subsequently referred to as "confiningunit layers") that separate the aquifer layers was estimated separately. Distinct spatial zones within the " 2,400 -foot" sand and the lowest confining unit (layer 21) were delineated north of the Baton Rouge fault between columns 32 and 70 to simulate greater vertical conductance between the " 2,800 foot" sand and the "2,400-foot" sand and increase simulated water levels within the "2,400-foot" sand in the vicinity of the Government Street pumping station (fig. 11). The $\mathrm{K}_{\mathrm{v}}$ of all aquifers and $\mathrm{K}_{\mathrm{h}}$ of all confining units were specified with a single parameter for each of these two types of hydrogeologic units (table 4), which were relatively insensitive during initial parameter estimation, and subsequently fixed at reasonable values. Separate parameters were defined to represent specific storage $\left(\mathrm{S}_{\mathrm{s}}\right)$ within each aquifer and confining-unit layer. Because water levels were specified for the top model layer (layer 1), $\mathrm{S}_{\mathrm{s}}$ for model layer 1, representing the " 400 -foot" sand, "600-foot" sand, and " 800 -foot" sand, had no effect on simulated water levels.

Because of the importance of fault-zone conductance in controlling the transport of saltwater across the Baton Rouge Fault, distinct hydraulic characteristics were estimated for six lateral segments of the Baton Rouge Fault within the 10 model layers (layers 9-18) representing the "2,000-foot" sand north of the fault. A single hydraulic characteristic was estimated for each of the other model layers (layers 3, 5, 7, 20, and 22) that contain aquifers north of the fault. The calibrated values of the hydraulic properties for the groundwater-flow model are summarized in table 4.

\section{Horizontal Interpolation of Hydraulic Conductivity}

Heterogeneity of horizontal hydraulic conductivity within the "2,000-foot" sand was interpolated by estimating values at 142 "pilot points" (Doherty, 2003) that were specified at selected well locations where borehole lithologic and (or) electric logs were available to constrain the estimated values. The values of 142 parameters, each representing $\mathrm{K}_{\mathrm{h}}$ at a single pilot point, were estimated during model calibration. The spatial interpolation between pilot-point locations was computed by ordinary kriging with an isotropic spherical variogram. The interpolated $\mathrm{K}_{\mathrm{h}}$ distributions in the " 2,000 foot" sand were smoothed to avoid "over fitting" and to constrain estimated values within a reasonable range by using two "regularization" methods (Doherty, 2003). The first method minimized the difference between pilot-point parameter values among neighboring pilot points, whereas "prior information" (Hill and Tiedeman, 2007) was assigned to the pilot points in the second method. The second method was deemed more appropriate and used $\mathrm{K}_{\mathrm{h}}$ values of 100 feet per day (ft/day) based on aquifer-pumping tests (Meyer and Turcan, 1955; Morgan, 1961, 1963). Parameter values at pilotpoint locations where an aquifer "pinched out" were fixed with $\mathrm{K}_{\mathrm{h}}$ equal to $1 \mathrm{ft} /$ day. The simulated hydraulic conductivity distribution resulting from the calibrated model parameters for the "2,000-foot" sand is illustrated in figure 13 . 


\section{Simulation of Groundwater Flow in the "1,500-Foot" Sand and "2,000-Foot" Sand in the Baton Rouge Area, Louisiana}

Table 4. Parameter values and sensitivities for the calibrated groundwater-flow model.

[ft, foot or feet; numbers in parameter names correspond to aquifer name or layer number (see table 2); $2 \mathrm{k}$, "2,000-foot" sand. The fault hydraulic characteristic of the "2,000-foot" sand was specified for 6 fault segments: fault_2k, fault_2kmid, fault_2ka, fault_2kb, fault_2kc, and fault_2kw.]

\begin{tabular}{|c|c|c|c|c|}
\hline Parameter type & Units & Parameter name & Calibrated value & Composite sensitivity \\
\hline Specified head & $\mathrm{ft}$ & bound_head & 121.0 & 1.80 \\
\hline \multirow[t]{11}{*}{ Horizontal hydraulic conductivity } & $\mathrm{ft} / \mathrm{day}$ & k_468sand & 30.0 & fixed \\
\hline & & k_1200sand & 34.1 & 1.00 \\
\hline & & k_1500sand & 240.0 & 0.07 \\
\hline & & k_1500neas & 63.1 & 0.52 \\
\hline & & $\mathrm{k} \_1500$ falt & 149.0 & 0.04 \\
\hline & & k_1700sand & 6.3 & 0.32 \\
\hline & & k_2000sand1 & See figure 13 & various \\
\hline & & k_2400sand & 10.0 & 0.38 \\
\hline & & k_2400sand2 & 40.0 & fixed \\
\hline & & k_2800sand & 35.8 & 0.88 \\
\hline & & k_clay & 1.E-5 & fixed \\
\hline \multirow[t]{8}{*}{ Vertical hydraulic conductivity } & $\mathrm{ft} / \mathrm{day}$ & vk_sands & 0.71 & fixed \\
\hline & & $\mathrm{vk} \_2 \mathrm{con}$ & $2.0 \mathrm{E}-5$ & 0.14 \\
\hline & & $\mathrm{vk} \_4$ con & $1.3 \mathrm{E}-4$ & 0.09 \\
\hline & & vk_6con & $1.0 \mathrm{E}-5$ & 0.07 \\
\hline & & vk_8con & $2.1 \mathrm{E}-3$ & 0.28 \\
\hline & & vk_19con & $6.8 \mathrm{E}-4$ & 0.26 \\
\hline & & vk_21con & $1.2 \mathrm{E}-5$ & 0.27 \\
\hline & & vk_gov & $6.0 \mathrm{E}-4$ & fixed \\
\hline \multirow[t]{12}{*}{ Specific storage } & $\mathrm{ft}^{1}$ & ss_sand & $1.0 \mathrm{E}-5$ & 0.09 \\
\hline & & ss_15 & $1.0 \mathrm{E}-6$ & 0.04 \\
\hline & & ss_17 & $8.0 \mathrm{E}-6$ & 0.14 \\
\hline & & ss_24 & $4.6 \mathrm{E}-6$ & 0.07 \\
\hline & & ss_28 & $2.2 \mathrm{E}-6$ & 0.06 \\
\hline & & ss_2ksand & $5.5 \mathrm{E}-6$ & 0.11 \\
\hline & & ss_clay2 & $1.1 \mathrm{E}-6$ & 0.01 \\
\hline & & ss_clay4 & $1.8 \mathrm{E}-6$ & 0.04 \\
\hline & & ss_clay6 & $1.0 \mathrm{E}-6$ & 0.04 \\
\hline & & ss_clay8 & $5.2 \mathrm{E}-6$ & 0.11 \\
\hline & & ss_clay19 & $1.2 \mathrm{E}-6$ & 0.04 \\
\hline & & ss_clay21 & $1.0 \mathrm{E}-6$ & 0.04 \\
\hline \multirow[t]{11}{*}{ Fault hydraulic characteristic } & day $^{1}$ & fault_lay_3 & $1.2 \mathrm{E}-4$ & 0.03 \\
\hline & & fault_lay_5 & $9.4 \mathrm{E}-6$ & 0.01 \\
\hline & & fault_lay_7 & $1.4 \mathrm{E}-3$ & 0.07 \\
\hline & & fault_2k & $6.0 \mathrm{E}-4$ & 0.02 \\
\hline & & fault_2kmid & $8.0 \mathrm{E}-5$ & 0.02 \\
\hline & & fault_2ka & $3.0 \mathrm{E}-5$ & 0.02 \\
\hline & & fault_ $2 \mathrm{~kb}$ & $3.0 \mathrm{E}-5$ & 0.02 \\
\hline & & fault_2kc & $3.0 \mathrm{E}-5$ & 0.02 \\
\hline & & fault_2kw & $1.0 \mathrm{E}-3$ & 0.02 \\
\hline & & fault_lay_20 & $1.0 \mathrm{E}-06$ & 0.01 \\
\hline & & fault_lay_22 & $4.2 \mathrm{E}-3$ & 0.02 \\
\hline
\end{tabular}

${ }^{1} 142$ additional parameters represented horizontal hydraulic conductivity at pilot points in these aquifers. 


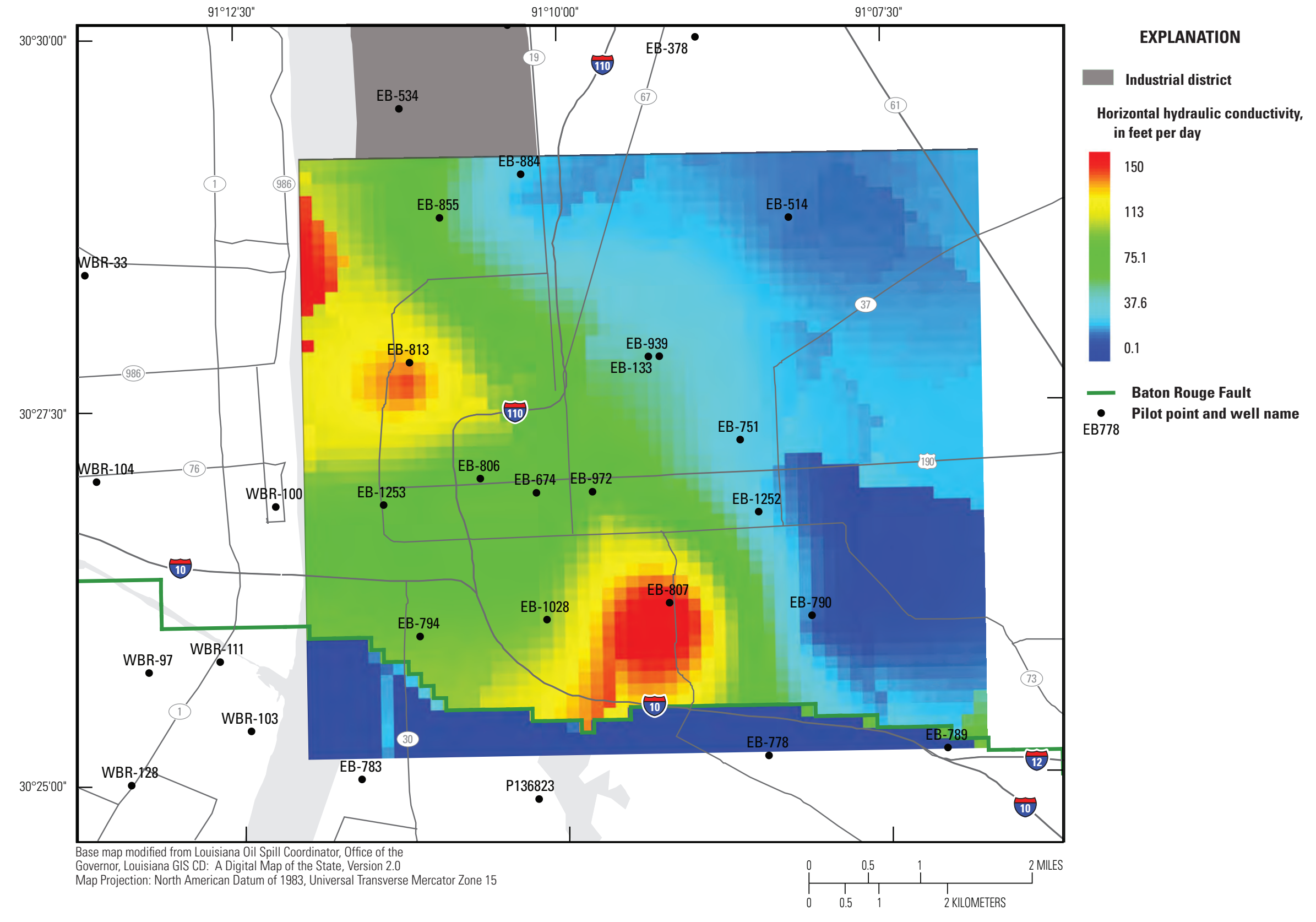

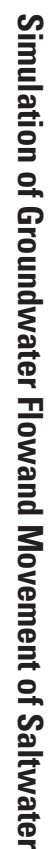

Figure 13. Map showing pilot-point locations and the simulated horizontal hydraulic conductivity distribution within the "2,000-foot" sand of the Baton Rouge area in the detailed model area in southeastern Louisiana. 


\section{Transport Properties}

Solution of the advection-dispersion equation with SEAWAT required definition of the spatial distribution of the longitudinal, transverse, and vertical dispersivities, diffusion coefficient, and effective porosity of the aquifer system within the solute-transport domain. A homogeneous distribution for each of these properties was specified. The longitudinal, transverse, and vertical dispersivities and effective porosity were estimated during calibration of simulated-to-observed chloride concentrations. Because the simulated transport processes are dominated by advection, diffusion is negligible, and the diffusion coefficient was specified equal to zero. The calibrated values of these parameters are summarized in the "Estimated Parameter Values" section of this report.

\section{Model Calibration}

The groundwater-flow model was calibrated to obtain the best overall agreement between measured heads and their corresponding values simulated with MODFLOW. Although water-level measurements were used as observations in the model-calibration regression, groundwater fluxes were constrained by specification of well withdrawals. By using the parameter-estimation code PEST (Doherty, 2004), the values of 185 parameters, which include 142 pilot-point parameters and the others summarized in table 4 , were adjusted to minimize the objective function:

$$
\sum_{k=1}^{3,612}\left(\omega_{k} H_{k}-\omega_{k} H_{k}^{\prime}(\mathbf{b})\right)^{2}+\sum_{i=1}^{N P R}\left(\omega_{i} P_{i}-\omega_{i} P_{i}^{\prime}(\mathbf{b})\right)^{2}
$$

In equation 4, symbols in the first summation are associated with water levels:

$$
\begin{aligned}
& H \quad \text { is the measured water level for observation } k, \\
& H^{\prime} \quad \text { is the simulated-equivalent water level for } \\
& \text { observation } k, \\
& \text { b is the vector of } 185 \text { model parameters, } \\
& \omega_{k} \quad \begin{array}{l}
\text { is the weight applied to water-level } \\
\text { observation } k \text {, and }
\end{array} \\
& \mathrm{N} \quad \text { is the number of water-level observations } \\
& (3,612) .
\end{aligned}
$$

Symbols in the second summation are associated with the "prior information" equations used for the regularization previously described in the "Horizontal Interpolation of Hydraulic Conductivity" section of this report: $\mathrm{P}_{\mathrm{i}}$ is the $i$ th prior estimate, $\mathrm{P}_{\mathrm{i}}{ }_{\mathrm{i}}$ is the $i$ th simulated value, $\omega_{i}$ is the weight applied to the $i$ th prior estimate, and NPR is the number of prior equations used to regularize the $\mathrm{K}_{\mathrm{h}}$ distributions specified for the "2,000-foot" sand in the regression, which equaled 138.

\section{Calibration Dataset}

The model calibration dataset consisted of observations of groundwater levels, connector-well flow, and chloride concentrations. PEST was used to calibrate the water levels simulated with the constant-density MODFLOW model to observed water-levels. The observed borehole flow through the "connector well" (fig. 11) was compared to the value simulated for the time of the observation, which assisted manual calibration of the $\mathrm{K}_{\mathrm{h}}$ specified in the top model layer. Observations of chloride concentrations were used to calibrate the transport model parameters. The flow model was calibrated through parameter estimation with PEST whereas the transport model was manually calibrated through trial and error.

\section{Water-Level Observations}

A total of 4,857 water levels measured during the period between 1940 and 2011 from 161 wells in Louisiana were utilized for the groundwater-flow model. These measurements were from wells with at least six annual measurements, and only one measurement per year from any well was incorporated into the calibration database. About 74 percent $(3,612)$ of these measurements from 137 wells that were measured before 2008 in aquifers beneath the " 800 -foot" sand were used to estimate parameters in the flow-model calibration. About 21 percent $(1,012)$ was used to evaluate the accuracy of transient water levels specified in the top model layer. The remaining 5 percent (233) that was measured during the period from 2008 through 2011 in aquifers beneath the " 800 -foot" sand were used to evaluate model fit during that period. In locations where multiple wells with overlapping periods of record exist, wells with the longest periods of continuous water-level record generally were selected for the compilation. Measured water-level altitudes were between 248 and $-292 \mathrm{ft}$. Measured water levels from the deeper observation wells used for estimation of flow-model parameters were between 215 and $-292 \mathrm{ft}$, a range of $507 \mathrm{ft}$.

Well location and construction information from USGS, DOTD, and DNR records were used to specify the screen intervals and locations of the observation wells. Water-level observations from wells screened within the " 400 -foot" sand, " 600 -foot" sand, and " 800 -foot" sand were assigned zero weights because water levels within layer 1 were specified throughout the simulation. Although effectively removed from the parameter-estimation regression, these observations were retained in the calibration dataset for evaluation of the waterlevel specification accuracy within layer 1 .

Most $(4,068)$ water-level observations were measured in wells with screen intervals corresponding to a single model layer, but 789 observations were measured in wells with either long or multiple screens that correspond to more than one model layer. In the latter cases, the measured water levels represent a composite of the actual head conditions in the various aquifer-depth intervals in which the well is screened. The majority of these multilayer observations were 
measured in wells screened in the "2,000-foot" sand, which is represented by 10 model layers with identical $\mathrm{K}_{\mathrm{h}}$ distributions. The composite water level simulated for each multilayer well was computed by averaging the water levels simulated in all the model layers intersected by the well screen.

Because of the paucity of water level measurements within the "2,400-foot" sand in the Baton Rouge area, several solitary water level measurements documented by Tomaszewski and Accardo (2004) that were not included in the water-level observation during the parameter-estimation regression were subsequently utilized to manually calibrate water levels within that sand.

\section{Wellbore-Flow Observation}

Following installation and initial development of well EB-1293, which is the "connector well" (fig. 11) providing a conduit between the "800-foot" sand and "1,500-foot" sand, a flow rate of about 475 gallons per minute (gpm) from the " 800 -foot" sand to the "1,500-foot" sand was measured with a calibrated flow meter during December 1998 (Dial and Cardwell, 1999). The simulated flow through the "connector well" was fitted to the measured flow by adjusting the $\mathrm{K}_{\mathrm{h}}$ for model layer 1, which represents the "400-foot" sand, "600-foot" sand, and "800-foot" sand. Because further well development was conducted before the well was officially placed in service on April 6, 1999, it is possible that the ambient flow though the "connector well" since that time has been greater than the initial measurement. Multiple measurements of water levels in EB-1293 were also used for model calibration with PEST.

\section{Concentration Observations}

Two hundred eighty-three chloride-concentration observations from 16 wells within the "2,000-foot" sand were compiled from the USGS National Water Information System (NWIS) (U.S. Geological Survey, 2013) for calibration of the transport simulation. Five wells (EB-781, EB-1028, EB-1150, EB-630, and EB-807B; fig. 11) were located in the area of saltwater encroachment and had sufficiently long periods of record to be useful calibration targets.

\section{Water-Level Observation Errors}

Quantification of the various sources of error that contribute to the uncertainty of water-level measurements is desirable for calculation of the measurement weights in the regression equations used during model calibration. The sources of water-level measurement error in the calibration dataset were categorized as follows: (1) errors in the measured location and altitude of the observation-well measurement point and (2) errors in depth-to-water measurements. The altitudes of the measurement points of most water-level observation wells were interpolated from local USGS 7.5-minute quadrangle topographic maps that have a 5-ft contour interval. The uncertainty of each altitude determined from these maps is within one half of the contour interval, or $2.5 \mathrm{ft}$. Most depth-to-water level measurements used for model calibration were made by using steel or electrical tapes with an estimated accuracy of $0.01 \mathrm{ft}$. Water levels at flowing wells, where the water level was above land surface, were measured using calibrated pressure gages with an estimated accuracy of $0.1 \mathrm{ft}$. Because the vast majority of water-level measurements used in the model were from wells in the Baton Rouge area which have not flowed since the 1940s, the average error associated with the depth-to-water measurements is assumed to be $0.01 \mathrm{ft}$. Transient water-level fluctuations caused by processes not simulated by the model, such as atmospheric pressure fluctuations, earth tides, or unreported groundwater withdrawals are termed "nonsimulated transient-stress errors." Although it can be advantageous to estimate the "error" associated with such nonsimulated transient stresses to appropriately weight measurements from "noisy" water-level records, the magnitude of these errors was not quantified. The total error for water-level measurements was estimated as the sum of errors in measurement-point altitude and depth to water, which is about $2.5 \mathrm{ft}$.

\section{Weights}

The uncertainties associated with measurement of wellhead altitudes and the depth to water in the observation well were converted to variances and summed to obtain an error variance associated with each water-level measurement (Hill and Tiedeman, 2007). The inverse of this composite variance can be used to assign a measurement weight in the modelcalibration regression. Because all well-head altitude and depth-to-water measurement errors in the calibration dataset were deemed to be similar, the resulting observation weights were normalized for observations used in the regression. Because well-withdrawal data from 2007 was extrapolated to simulate the period from 2008 through 2011, waterlevel measurements from that period are likely affected by withdrawals that are not accurately simulated by the model (a "nonsimulated transient stress error"). Accordingly, waterlevel observations from the period 2008 through 2011 were assigned zero weight, as were observations corresponding to specified head boundaries. Because PEST automatically adjusts the weight of the set of prior information equations with respect to the set of observations during the parameterestimation process, the relative weight assigned to the set of prior information equations versus the set of observations was not important.

\section{Calibration Assessment}

The quality of the model calibration was evaluated on the basis of the reasonableness of the estimated parameter values, the overall fit of simulated-to-observed water levels measured 
by the objective function, the fit of simulated-to-observed chloride values, and the lack of bias in the distribution of positive and negative water-level residuals. Summary statistics were calculated for the residuals (simulated minus observed water levels) of the 3,612 water-level observations used in the regression. The mean magnitude of the waterlevel residuals was $12 \mathrm{ft}$. The standard error of the regression (Draper and Smith, 1998) was $16.28 \mathrm{ft}$. The root-meansquare error (RMSE) was calculated as the square root of the mean of the unweighted squared residuals:

$$
R M S E=\sqrt{\frac{\sum_{k=1}^{3,612}\left(H_{k}-H^{\prime}{ }^{2}\right)^{2}}{3612}}
$$

where

$$
\begin{aligned}
& H \quad \text { is the measured water level for observation } \\
& k, \text { and } \\
& H^{\prime} \quad \text { is the simulated-equivalent water level } \\
& \text { for observation } k .
\end{aligned}
$$

The RMSE and the standard deviation of the residuals were both $15.85 \mathrm{ft}$. The normalized root-mean-square deviation is 0.031 and was obtained by dividing the RMSE of the residuals by the $507 \mathrm{ft}$ range of observed water levels. Because the RMSE is about 3 percent of the observed measurement range, the model is adequately calibrated for the purpose of this study.

\section{Estimated Parameter Values}

Parameter values were constrained within "reasonable limits" during the model calibration process with PEST. Several relatively insensitive model parameters drifted toward their respective limiting constraints between successive parameter-estimation iterations but were not allowed to exceed those limits. Consequently, all of the groundwater-model parameters in the "calibrated" MODFLOW-2005 and SEAWAT simulations (table 4) are considered reasonable.

Whereas the groundwater-flow model parameters were formally estimated by minimization of the objective function (equation 4), parameters representing the longitudinal, transverse, and vertical dispersivities and effective porosity in the solute transport model were estimated by manual calibration of simulated-to-observed chloride concentrations. The longitudinal component of the aquifer dispersivity was specified homogeneously at $300 \mathrm{ft}$, the transverse at $30 \mathrm{ft}$, and the vertical at $3 \mathrm{ft}$. Effective porosity was homogeneously specified at 15 percent. These values are within the range of reasonable values for these transport parameters (Zheng and Bennett, 1995).

\section{Parameter Sensitivities}

The composite parameter sensitivity reflects the total amount of information provided by the water-level observations for the estimation of the model parameter (Hill and Tiedeman, 2007). PEST computes a "composite sensitivity" (Doherty, 2004) of each model parameter with respect to all the weighted simulated heads $\left(h_{\mathrm{i}}^{\prime}\right)$. The composite sensitivities of parameters included in the regression computed at the final parameter values are summarized in table 4. In general, parameters with sensitivities greater than about 0.1 were well estimated and have correspondingly smaller confidence intervals. Parameters with composite scaled sensitivities smaller than about 0.1 were more difficult to estimate and (or) have larger confidence intervals.

\section{Residual Plot}

A graph of the water-level residuals (measured water levels minus simulated water levels) plotted as a function of the simulated water levels can be useful for detecting trends in the distribution of residuals, which may indicate model bias. Residuals for water levels measured north of the Baton Rouge Fault in the "2,000-foot" sand and in other aquifers are plotted with separate symbols in figure 14. The residuals for these observation groups are randomly distributed about the horizontal residual $=0$ abscissa, suggesting a lack of systematic model bias in simulated water levels.

\section{Simulated Groundwater Conditions}

In areas of constant groundwater density, the horizontal component of groundwater flow is generally in the direction of decreasing simulated water levels. Because the simulated chloride concentrations are relatively high in some areas adjacent to the Baton Rouge Fault, the contours of simulated water levels should not be used to infer the direction of groundwater flow in this area. The simulated water levels depicted as contour maps in this report represent conditions on December 31 of the indicated year. Comparisons between contour maps generated for different simulated times can be used to quantify water-level changes, and hydrographs of simulated and observed water levels at observation well locations can also be used to visualize water-level changes at various locations and depths within the aquifer system. Water levels simulated with SEAWAT that are presented in hydrographs in this report were computed with the Head Observation Package (HOB), which spatially and temporally interpolates simulated water levels at the location and time of each specified water-level observation. Changes in observed chloride concentration with time (chlorographs) and the corresponding concentrations simulated with SEAWAT are also presented in this report for selected wells. 


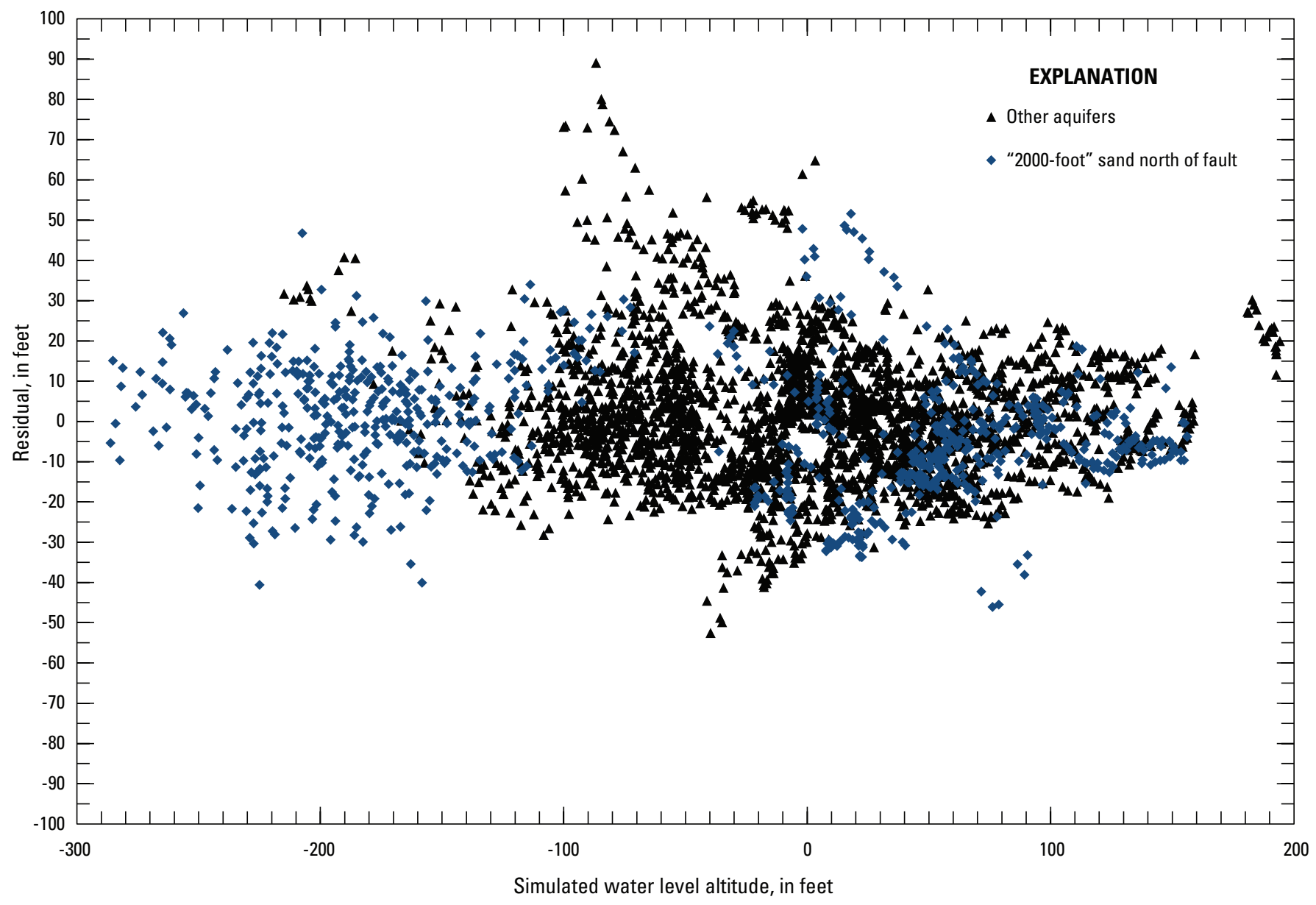

Figure 14. Graph showing residuals as a function of simulated water level altitudes for the "2,000-foot" sand and all other simulated aquifers. Residuals are calculated by subtracting simulated water-level altitudes from observed water-level altitudes.

\section{Simulated Water Levels}

Simulated groundwater flow within the "1,500-foot" sand during the "predevelopment" steady-state period prior to 1940 generally flowed from up-dip areas near the Louisiana-Mississippi border southward and southwestward toward the Baton Rouge area (fig. 15). Contours of simulated steady-state predevelopment water levels within the "2,000foot" sand suggest that groundwater flowed southward and southwestward toward Baton Rouge in areas east of the Mississippi River and may have flowed in a more westerly direction in areas west of the Mississippi River (fig. 16). Simulated groundwater flow within the "2,000-foot" sand and " 1,500 -foot" sand that flows toward the northwest corner of the model domain discharges upward toward the specifiedhead boundary that represents the surficial aquifers.

After 68 years of groundwater withdrawals (1940-2007), simulated groundwater levels in much of the study area declined from their predevelopment levels. Groundwater currently flows toward the Baton Rouge area where withdrawals from most of the simulated aquifers have caused substantial drawdown of water levels (fig. 17A). Within the "1,500-foot" sand, a simulated "cone of depression" (area of groundwater drawdown) is centered about 0.3 mi east of Interstate 110, where the minimum simulated water-level altitude is $-130 \mathrm{ft}$ (figs. $17 A$ and $17 B$ ). Within the "2,000-foot" sand, the area of greatest simulated drawdown is located in the industrial district northeast of well EB-367, where the minimum simulated water-level altitude is $-235 \mathrm{ft}$ (figs. $18 \mathrm{~A}$ and $18 B$ ). Lower water levels within the " 2,000 -foot" sand were simulated for years before 2007. For example, the water level simulated at the location of observation well EB-367, in which a water-level drawdown of $338 \mathrm{ft}$ was measured between 1937 and 1972, is about -281 ft for the year 1972.

Hydrographs that depict the fit of simulated and observed water levels for wells in the detailed model area (see figs. 11, 17 , and 18 for well locations) also show the history of waterlevel changes in the various aquifers (figs. 19-24). Simulated water levels depicted in the hydrographs were computed with the HOB package, which interpolated heads between model nodes for the well location and observation time, and averaged simulated heads for multilayer observations. A spreadsheet and 


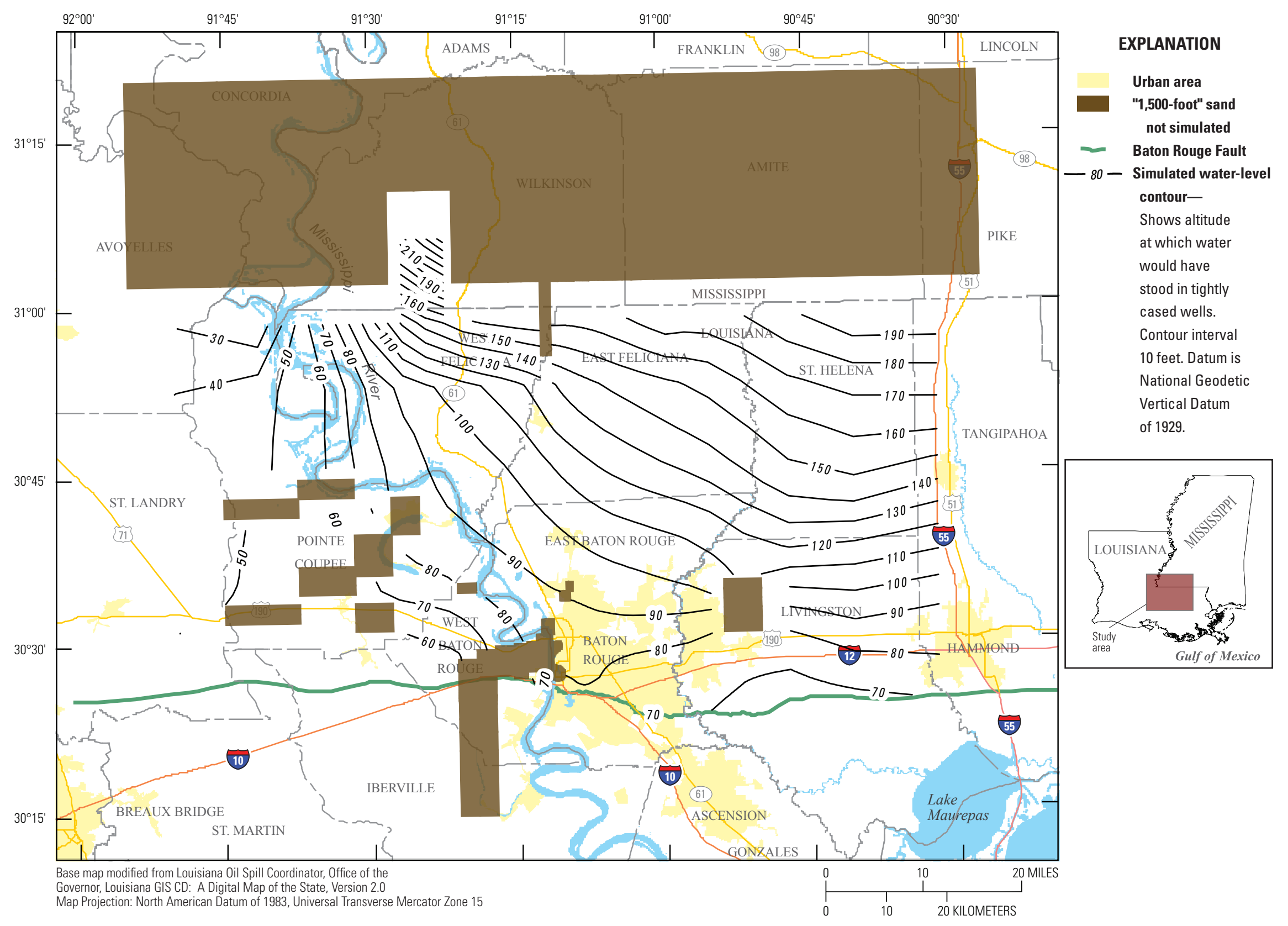

Figure 15. Map showing simulated steady-state water levels within the "1,500-foot" sand of the Baton Rouge area representing predevelopment conditions before 1940 in southeastern Louisiana and southwestern Mississippi. 


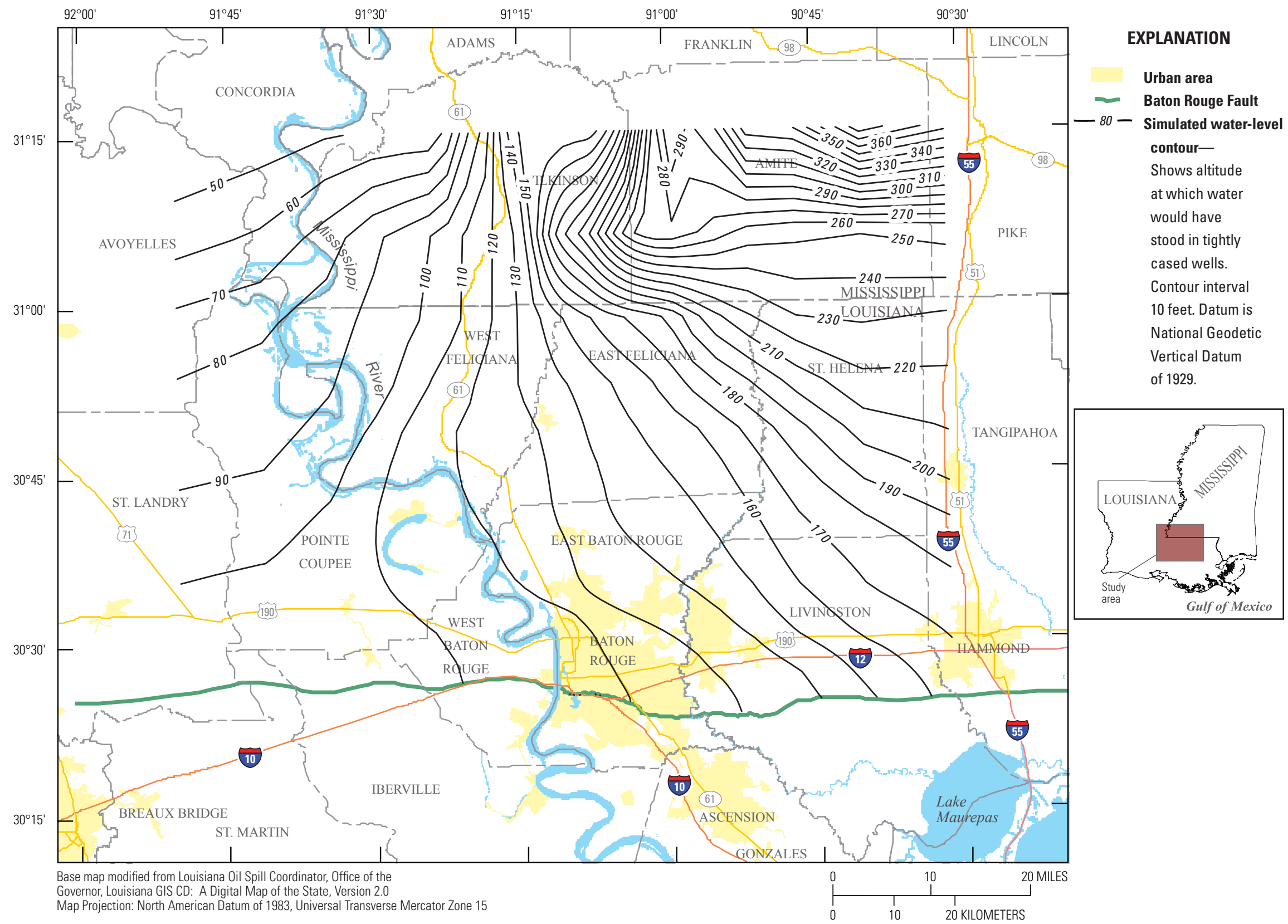

Figure 16. Map showing simulated steady-state water-levels within the "2,000-foot" sand of the Baton Rouge area representing predevelopment conditions before 1940 in southeastern Louisiana and southwestern Mississippi. 


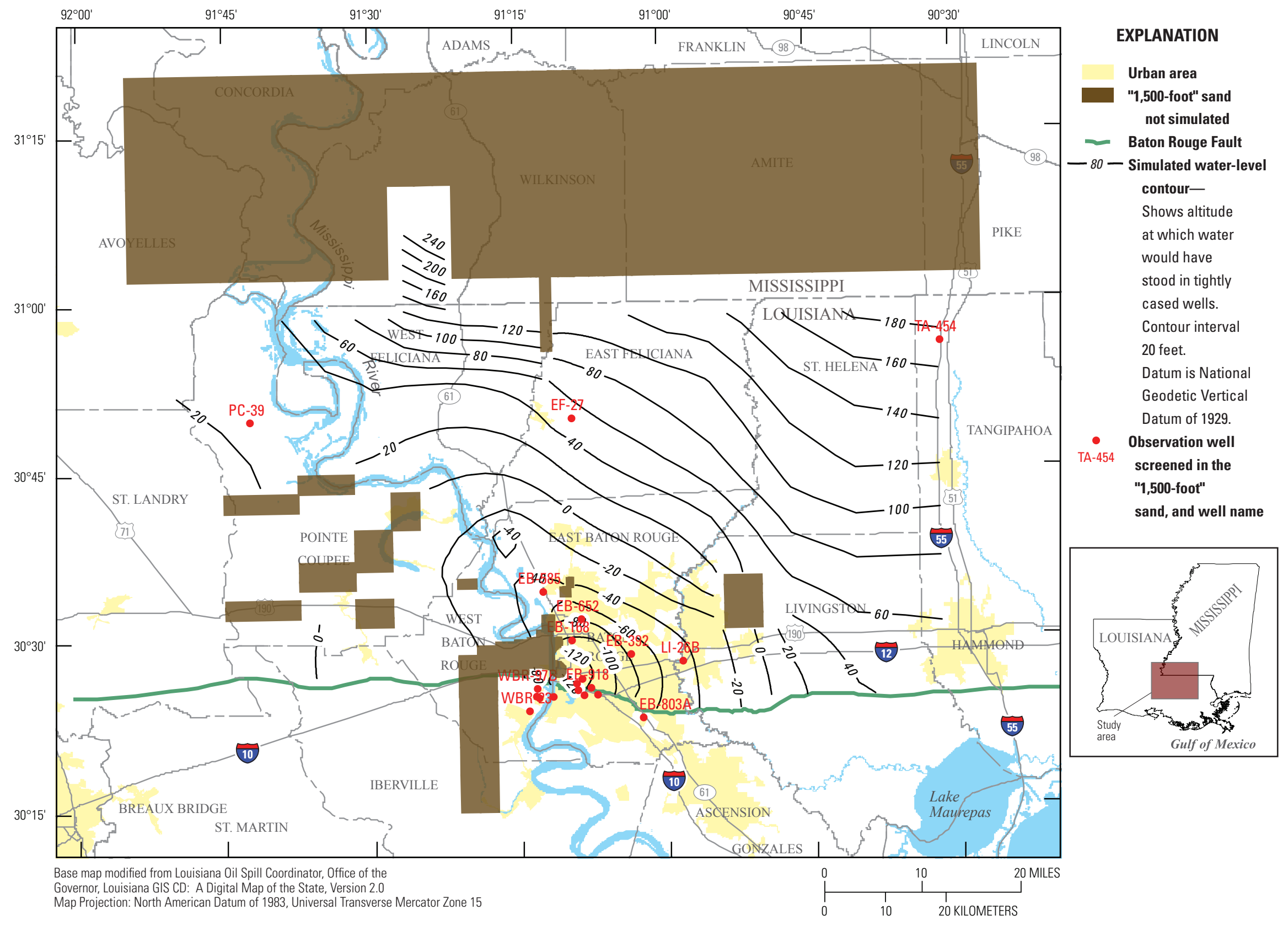

Figure 17A. Simulated 2007 water levels within the "1,500-foot" sand of the Baton Rouge area in southeastern Louisiana and southwestern Mississippi. 


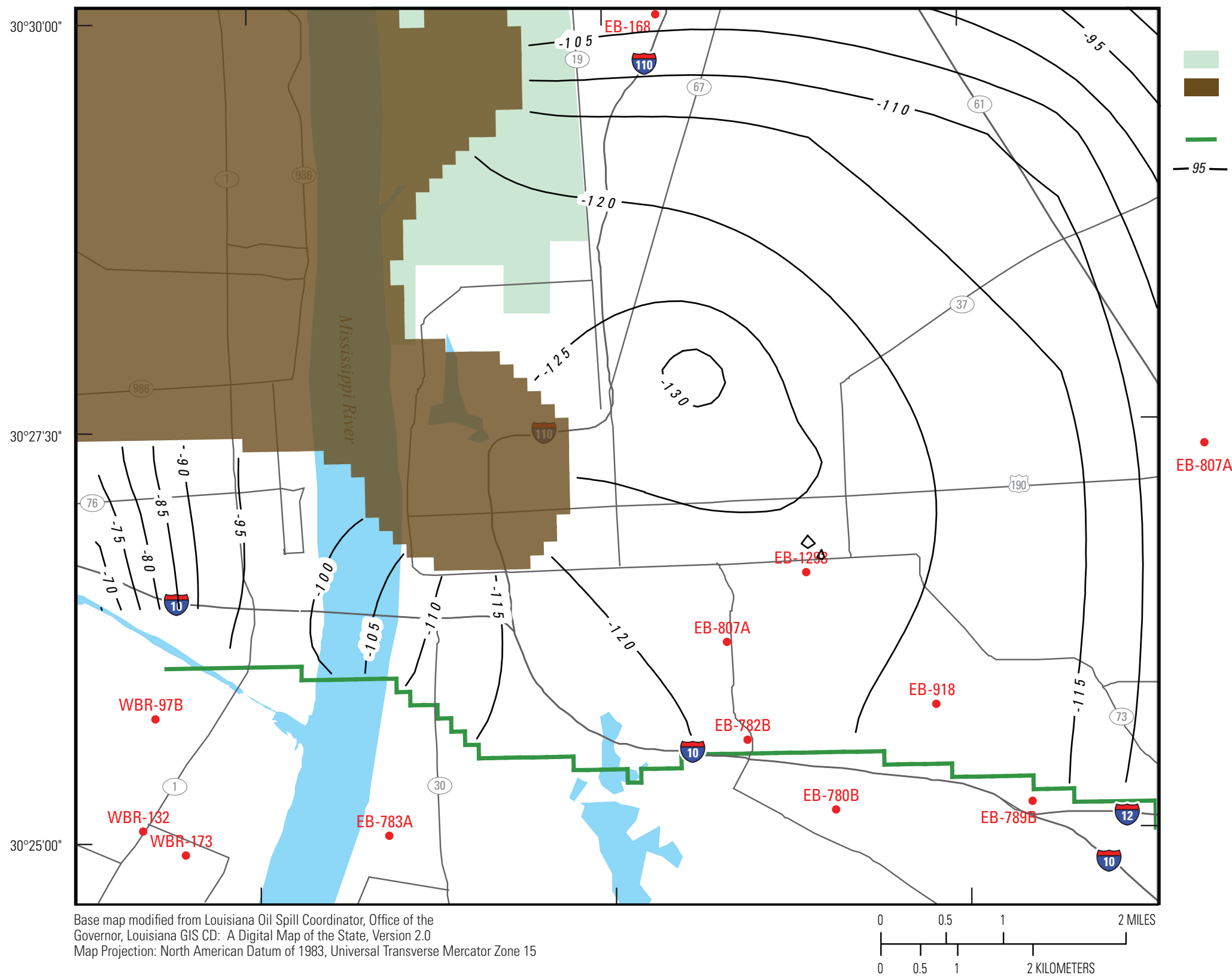

\section{Baton Rouge Fault}

Simulated waterlevel contour-

Shows altitude at which water would have stood in

tightly cased wells.

Contour interval

5 feet. Datum is

National Geodetic

Vertical Datum

of 1929

Observation well

screened in the

"1,500-foot" sand

and well name 


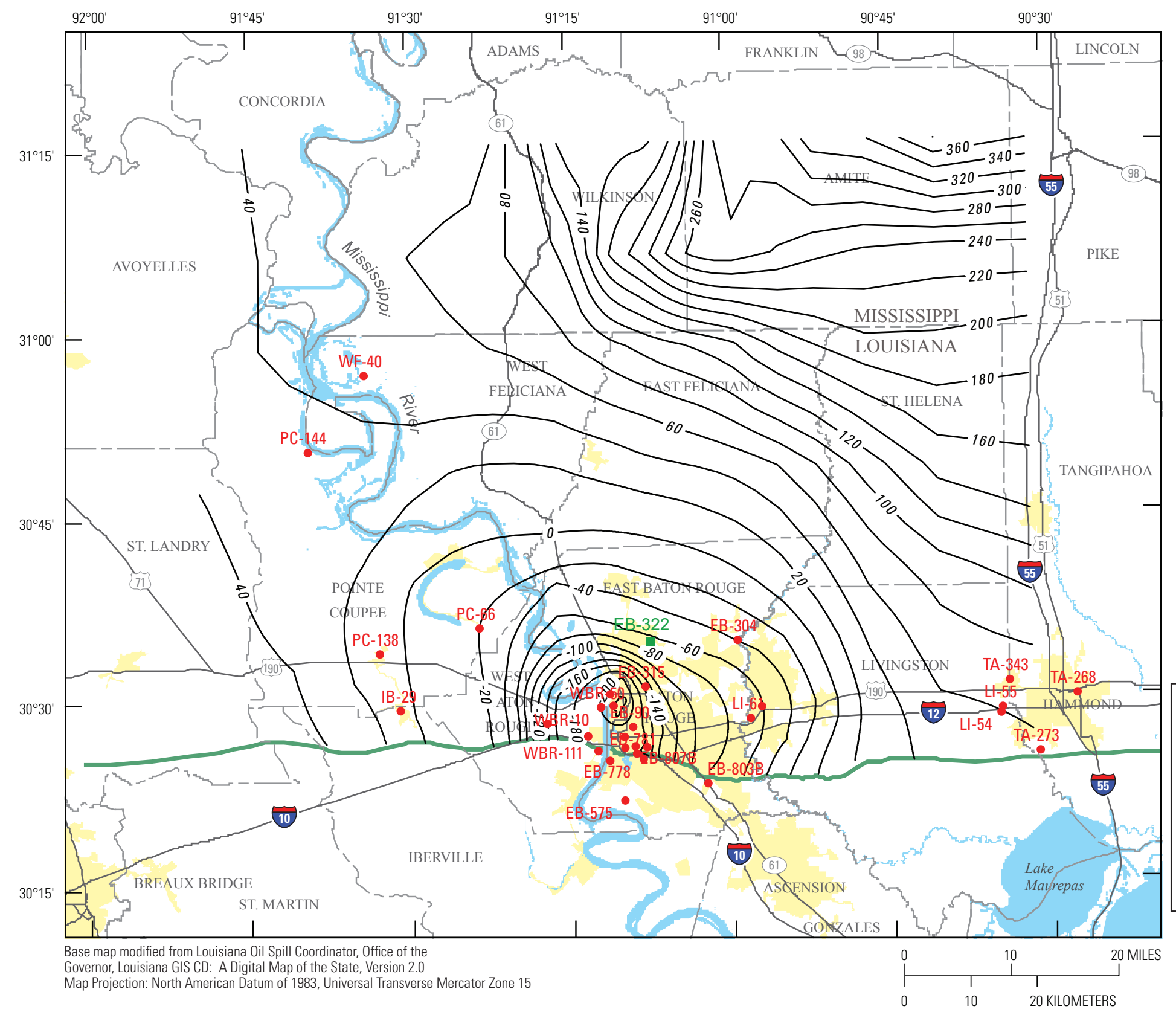

EXPLANATION

Urban area

Baton Rouge Fault

- 80 - Simulated water-

level contour-

Shows altitude

at which water

would have

stood in tightly

cased wells.

Contour inter-

val 20 feet.

Datum is Nat-

ional Geodetic

Vertical Datum

of 1929.

- Observation well

EB-575 screened in the

"2,000-foot" sand,

and well name

Observation well

EB-322

screened in the

"2,400-foot" sand,

and well name

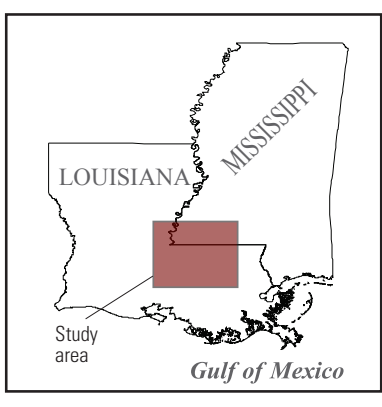

Man Projection: North American Datum of 1983, Universal Transwerse Mercator Zone 15

Figure 18A. Simulated 2007 water levels within the "2,000-foot" sand of the Baton Rouge area in southeastern Louisiana and southwestern Mississippi. 


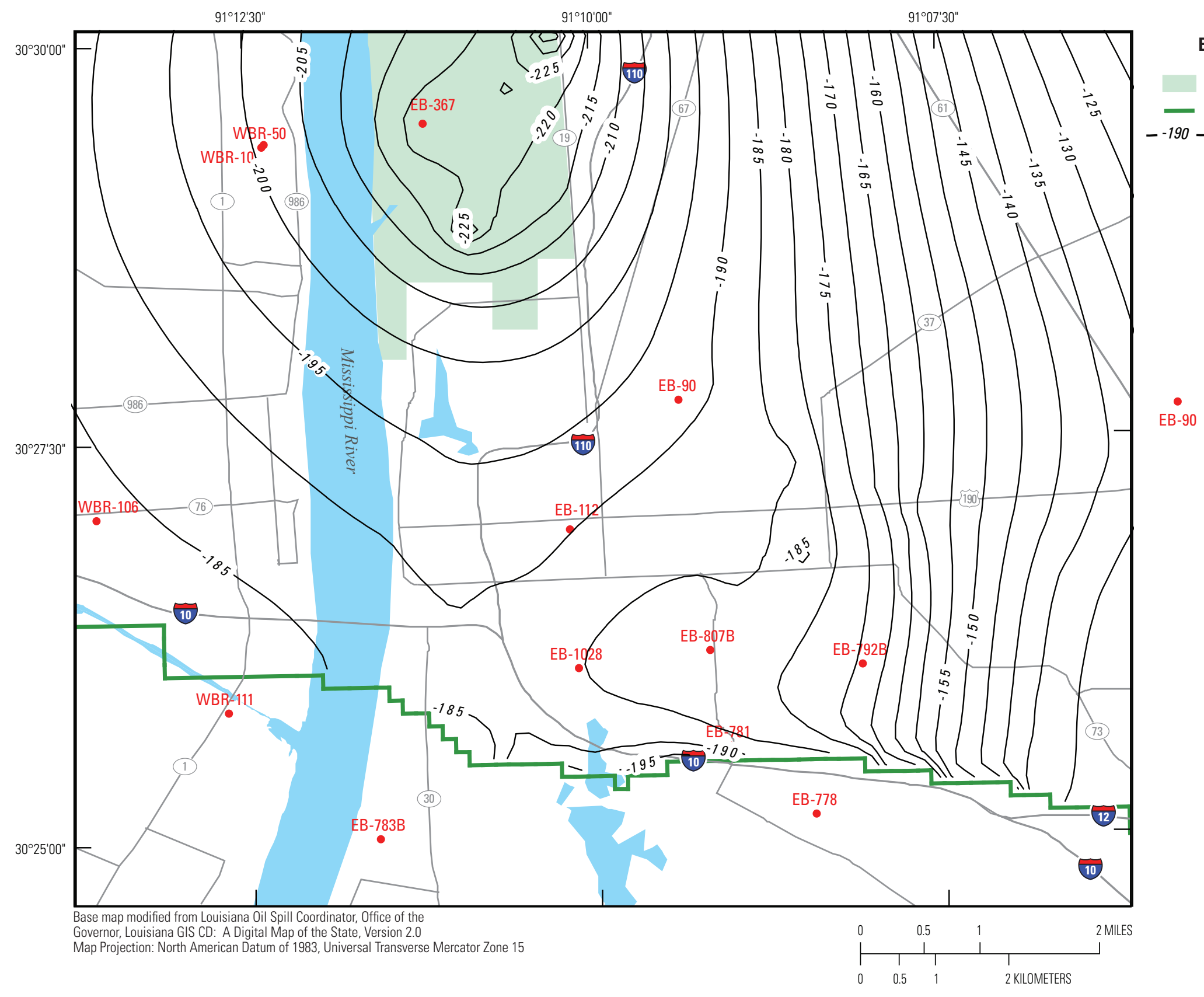

EXPLANATION

Industrial district Baton Rouge Fault ulated waterlevel contourShows altitude at which water would have stood in

tightly cased wells. Contour interval

5 feet. Datum is National Geodetic Vertical Datum of 1929.

Observation well screened in the "2,000-foot" sand and well name

Figure 18B. Simulated 2007 water levels within the "2,000-foot sand of the Baton Rouge area in the detailed model area in southeastern Louisiana. 
database containing hydrograph information for all observed and simulated water-levels are included with the digital archive of this groundwater model that is on file at the USGS office in Baton Rouge.

Water levels in the "1,000-foot" sand and "1,200-foot" sand are simulated by model layer 3 north of the fault. Although a uniform hydraulic conductivity was estimated for this model layer, the simulated transmissivity is variable because the model-layer thickness is variable. The fit of simulated-toobserved water levels shown in hydrographs (fig. 19) is good, and the $177 \mathrm{ft}$ of drawdown observed in well EB-146, (located about 0.9 mi east of Interstate 110 in Baton Rouge), is well simulated. Simulated water levels at some wells (EB-146, EB-299, and EB-301) are lower than observed during the 1960s and early 1970s, possibly as a result of inaccurate pumpage specified within this layer for those periods.

Water levels in the "1,500-foot" sand north of the fault were simulated by model layer 5 by using four spatial zones of horizontal hydraulic conductivity. The hydrograph for well EB-807A documents $82 \mathrm{ft}$ of drawdown between the years 1967 and 1992, which was the largest observed water-level change in the "1,500-foot" sand (fig. 20).

Water levels in the "1,700-foot" sand north of the fault were simulated with model layer 7 with a homogeneous horizontal hydraulic conductivity distribution. Although most observed water levels are well simulated, the water-level recovery at well EB-792A during the early 1970s was not (fig. 21 ), possibly as a result of inaccurate pumpage specified within this layer in the vicinity of EB-792A for that period.

Water levels in the "2,000-foot" sand were simulated by model layers 9 through 18 , each of which has an identical, complex distribution of simulated horizontal hydraulic conductivity (fig. 13). Observations of water levels in the "2,000-foot" sand are closely simulated throughout most of the model domain, particularly in the detailed model area. Locations of wells that are screened within the " 2,000 -foot" sand in the detailed model area that were used for model calibration are shown on figure $18 B$. A 368-ft water-level drawdown measured in well EB-112 between 1930 and 1973 is well simulated (fig. 22B). Water-level drawdowns of similar magnitude measured in other wells in the detailed model area are also well simulated by the model.

Water levels in the " 2,400 -foot" sand were simulated by model layer 20 by using two spatial zones of horizontal hydraulic conductivity. Water levels measured in two wells within the detailed model area, EB-794 and EB-806B (fig. 11), document about $100 \mathrm{ft}$ of water-level drawdown between 1965 and 2007 (figs. 23B,C). Considering the relatively simple hydraulic conductivity distribution used to simulate the "2,400foot" sand, water levels throughout the model domain are well simulated.

Because chloride concentrations in the " 2,800 -foot" sand are relatively high in the Baton Rouge area, only one well screened in the "2,800-foot" sand, EB-944 (fig. 24), was available to depict water levels in the detailed model area (fig. 11). Despite the scarcity of observation wells screened in the "2,800-foot" sand in the detailed model area, 15 other hydrographs within the "2,800-foot" sand outside of the detailed model area (not shown) also depict good model fit.

\section{Simulated Connector-Well Flow Rate}

The simulated transient flow through the "connector well," EB-1293, was compared with the previously described wellbore-flow observation during model calibration. The simulated flow rate of $480 \mathrm{gpm}(0.69 \mathrm{Mgal} / \mathrm{d})$ through this well during December 1998 is a good fit to the measured value of $475 \mathrm{gpm}$ reported by Dial and Cardwell (1999). The flow simulated through this "connector well" increases after December 1999 because simulated water levels within the "1,500-foot" sand generally decline faster than water levels specified for the " 800 -foot" sand, which increases the hydraulic gradient between those aquifers at that location. The maximum simulated flow rate of $660 \mathrm{gpm}$ occurred after installation of the connector well during early 1998, and before simulated water level differences between the " 800 -foot" sand and "1,500-foot" sand near EB-1293 had sufficient time to begin equilibration.

\section{Simulated Water Budget}

Under predevelopment (steady-state) conditions, the simulated water budget indicates that about $70 \mathrm{Mgal} / \mathrm{d}$ of water entered (and exited) the groundwater-flow model domain (table 5). The majority of the inflow (97.5 percent) was from the top model layer, which is a specified head boundary that represents the " 400 -foot" sand, " 600 -foot" sand, and " 800 -foot" sand aquifers. A small amount of inflow and outflow was simulated entering and exiting the model domain through the constanthead boundary along the southernmost row (row 85 ) of the deepest model layer (layer 22). By the end of the transient historical simulation (December 31, 2007), substantial net groundwater withdrawals (168.22 Mgal/d during 2007) had caused water-level declines that increased simulated infiltration from layer 1 by 67 percent, to $115.2 \mathrm{Mgal} / \mathrm{d}$. Water that flows into a model layer through a multi-node well comes out from another model layer connected to the same well. Specified water-level changes in the top model layer account for processes not explicitly simulated by the model, including storage changes in the upper "400-foot" sand, "600-foot" sand, and "800-foot" sand aquifers; evapotranspiration; and recharge. As such, recharge and discharge to the upper aquifers are not represented in the simulated water budget. Inflows from storage simulated in model layers 2-22 are from aquifer-matrix compression and water expansion.

A graph of the changes in the contributions from the three major sources and sinks of water during the transient historical groundwater simulation illustrates the effect of groundwater withdrawals on the simulated water budget (fig. 25). Following the steady-state stress period that simulates "predevelopment" conditions prior to 1940 , groundwater withdrawals are initially mostly supplied by the elastic release of water from storage. 

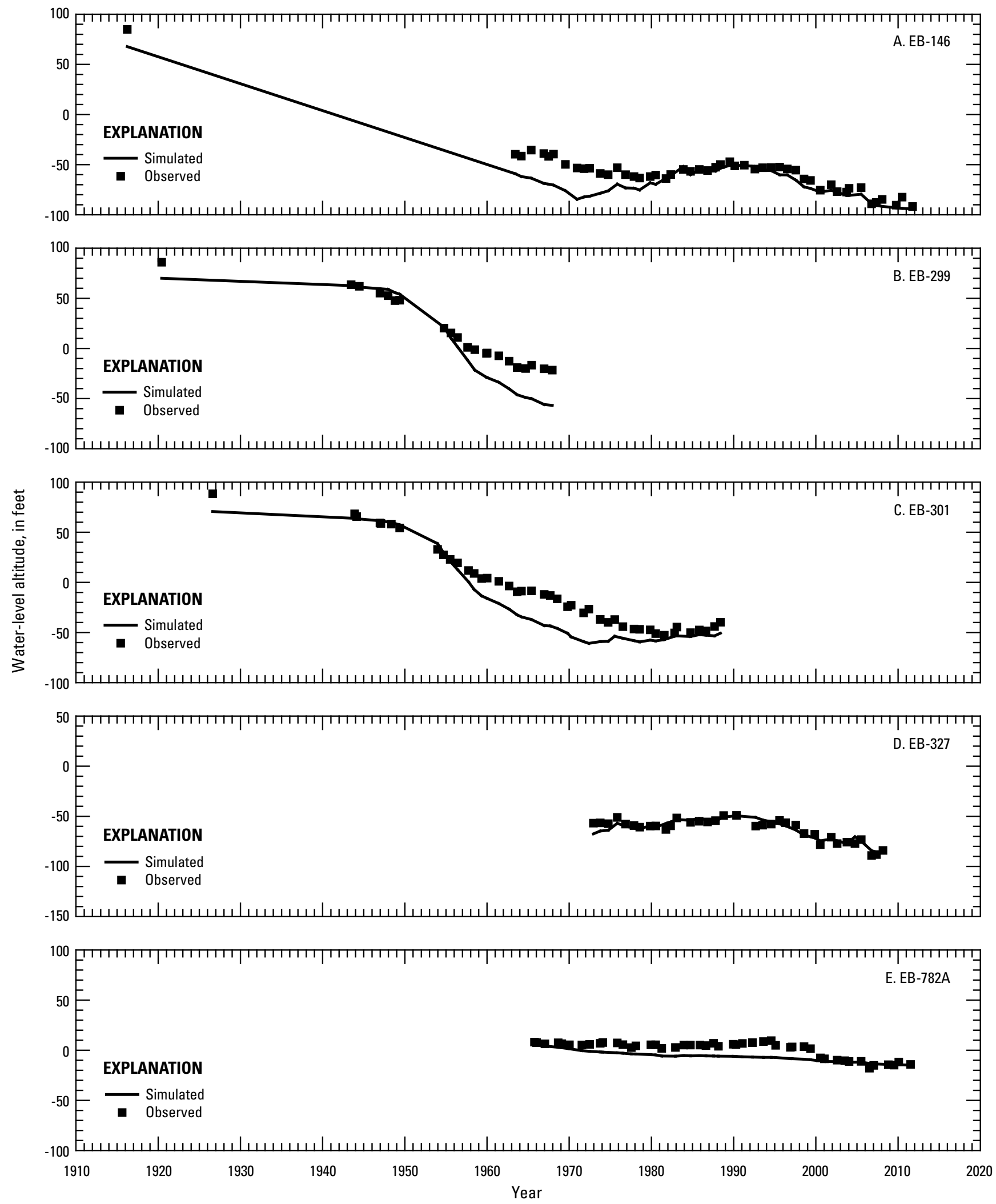

Figure 19. Graphs showing simulated and observed water levels within the "1,000-foot" and "1,200-foot" sands of the Baton Rouge area in southeastern Louisiana. 

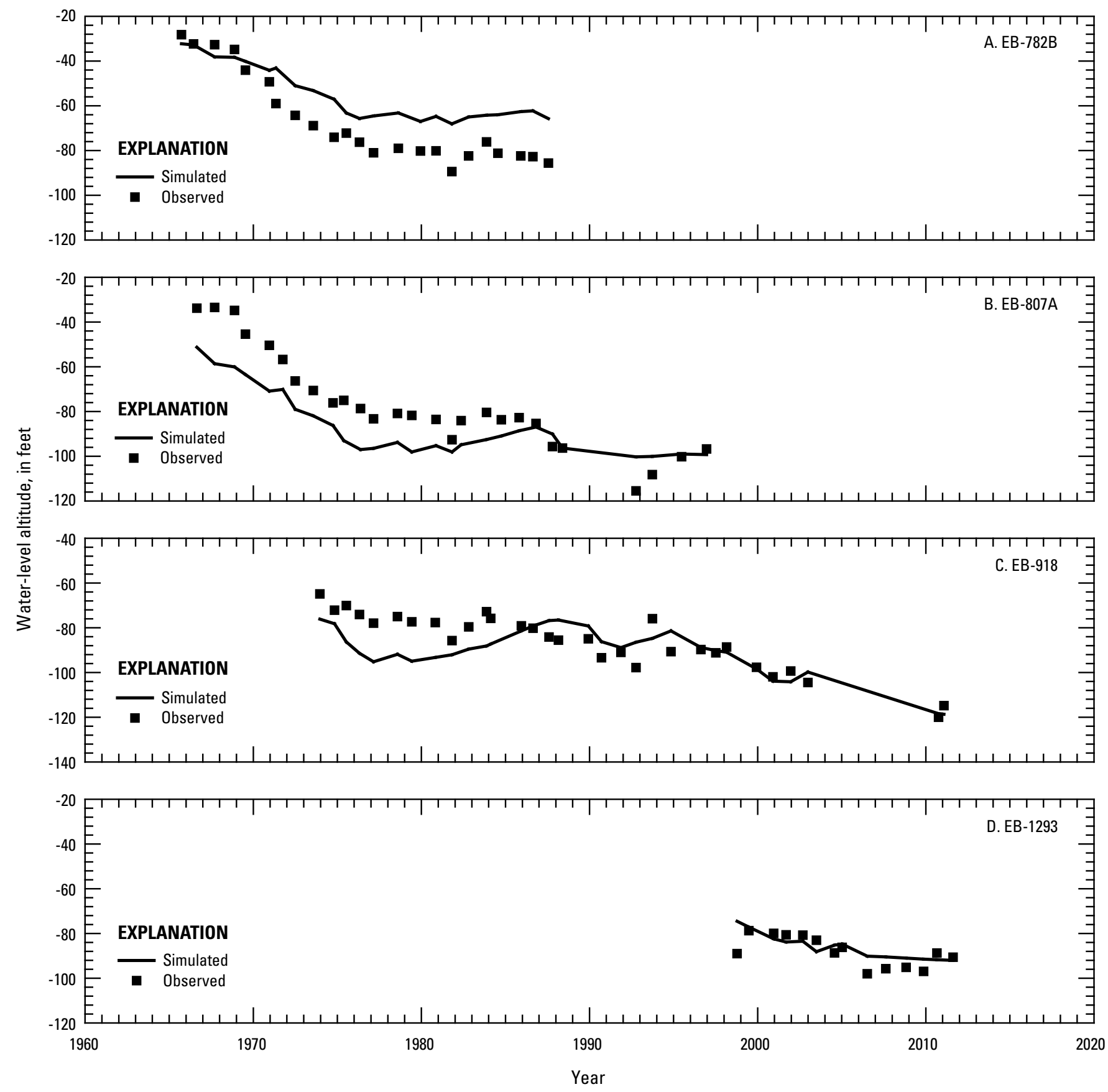

Figure 20. Graphs showing simulated and observed water levels within the "1,500-foot" sand of the Baton Rouge area in southeastern Louisiana. 

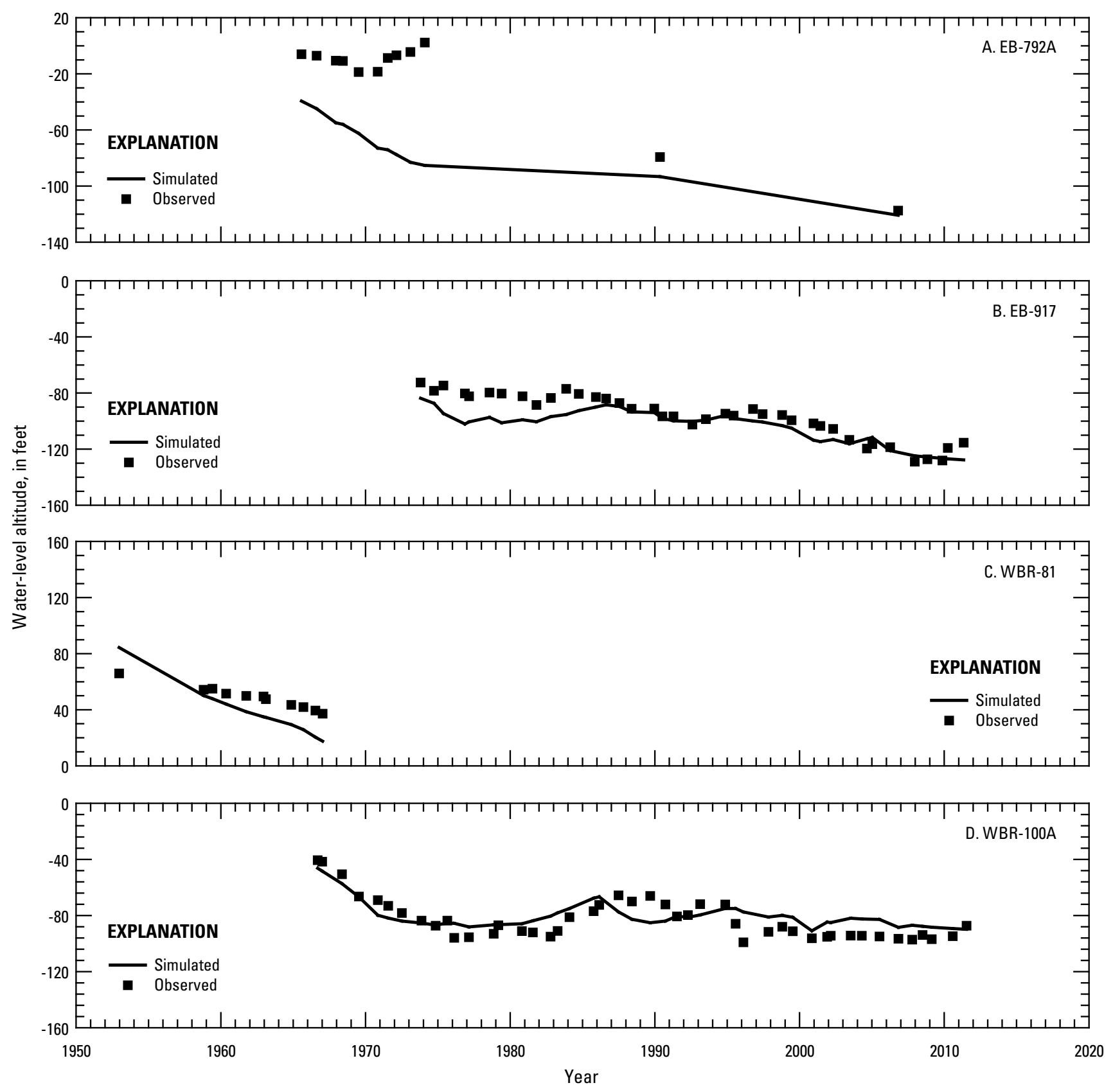

Figure 21. Graphs showing simulated and observed water levels within the "1,700-foot" sand of the Baton Rouge area in southeastern Louisiana. 

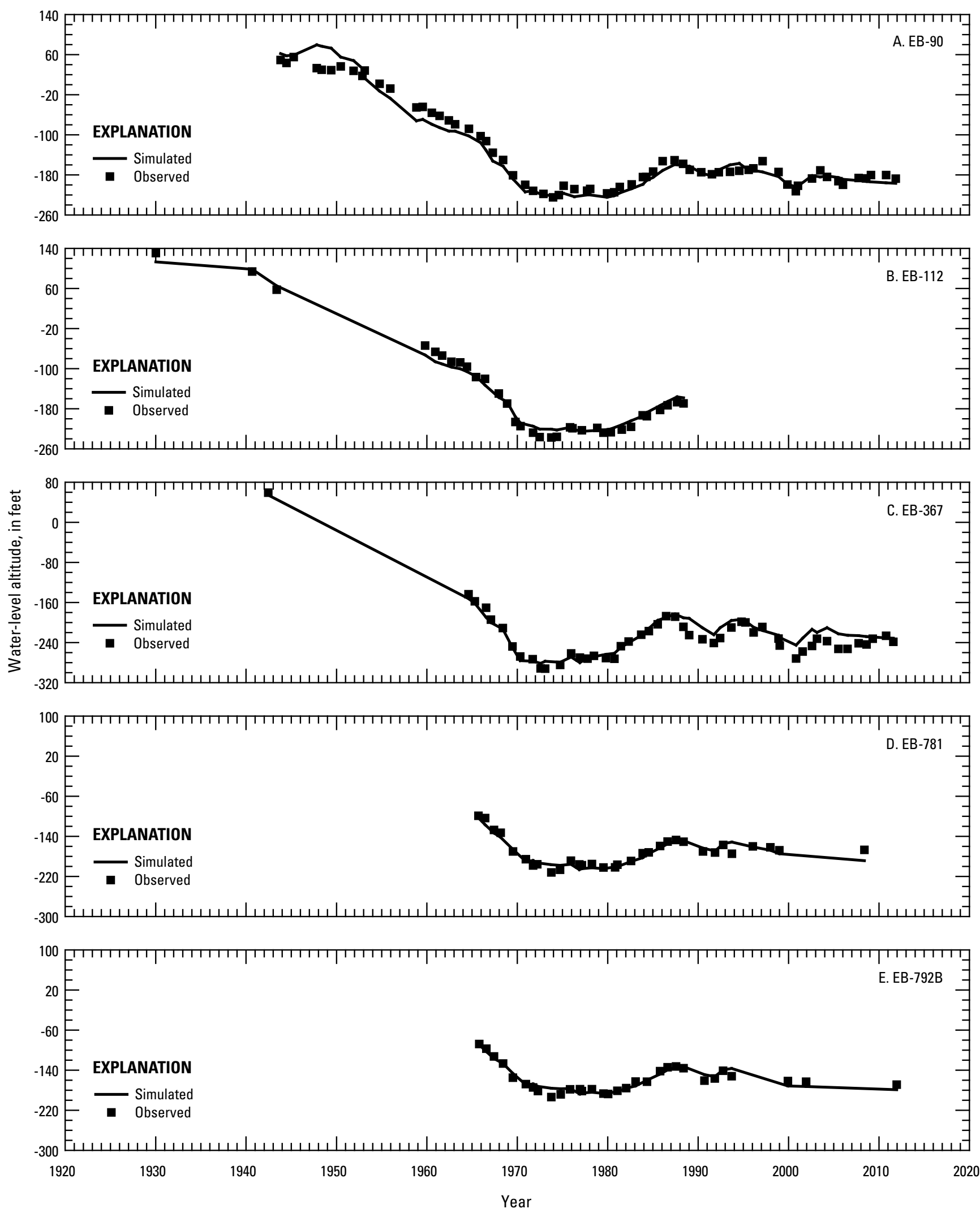

Figure 22. Graphs showing simulated and observed water levels within the "2,000-foot" sand of the Baton Rouge area in southeastern Louisiana. 

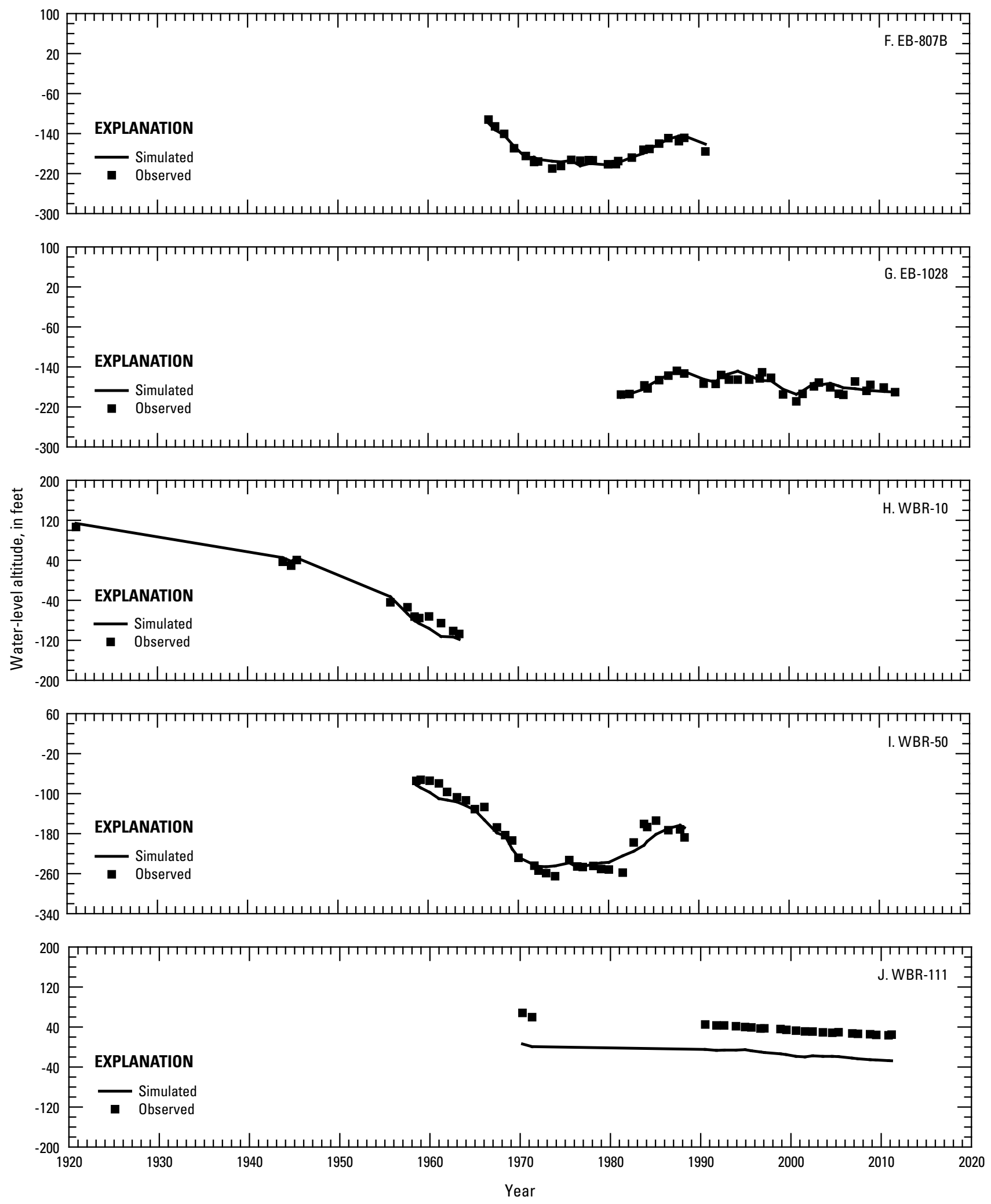

Figure 22. Graphs showing simulated and observed water levels within the "2,000-foot" sand of the Baton Rouge area in southeastern Louisiana.-Continued 

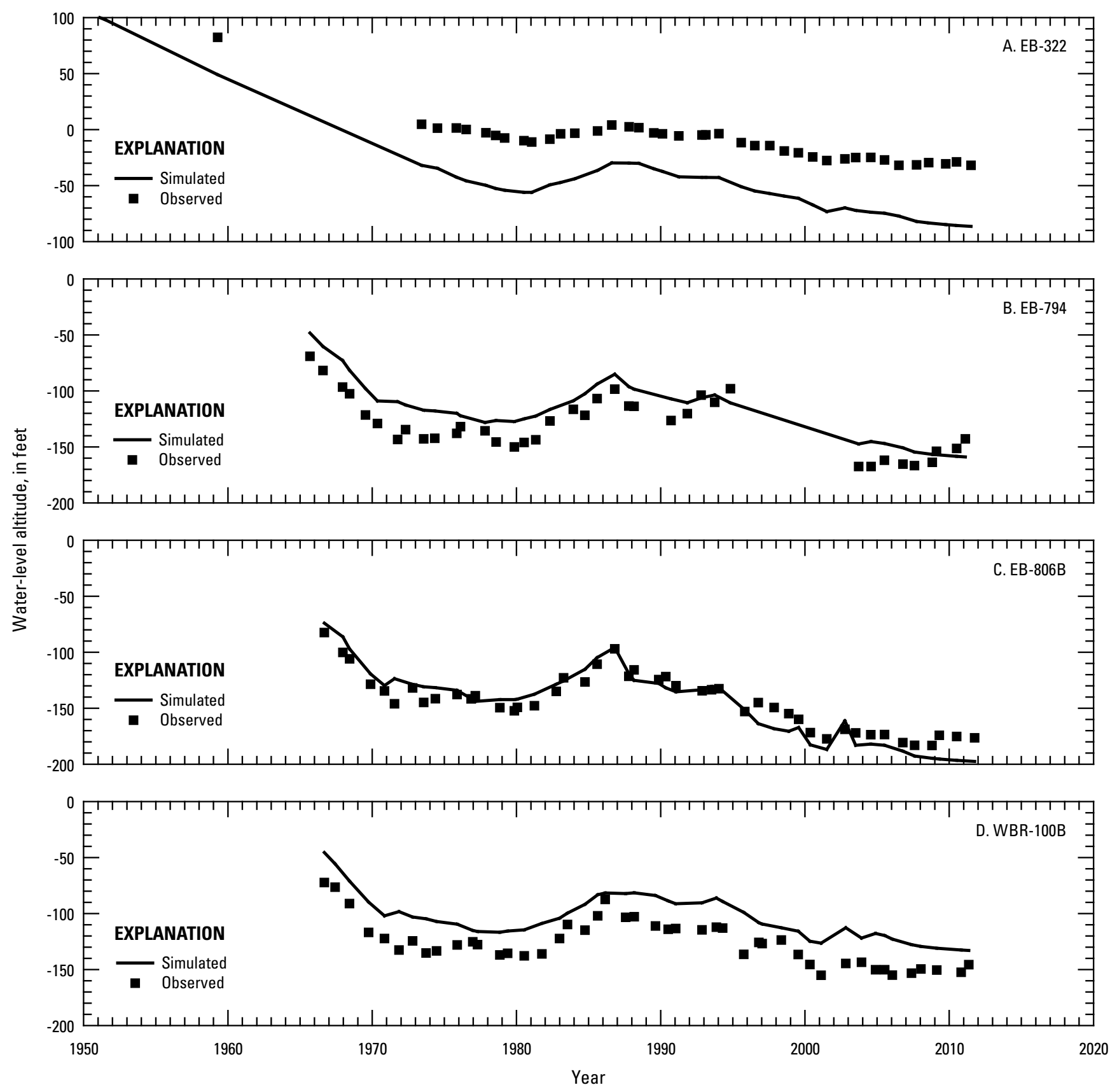

Figure 23. Graphs showing simulated and observed water levels within the "2,400-foot" sand of the Baton Rouge area in southeastern Louisiana. 


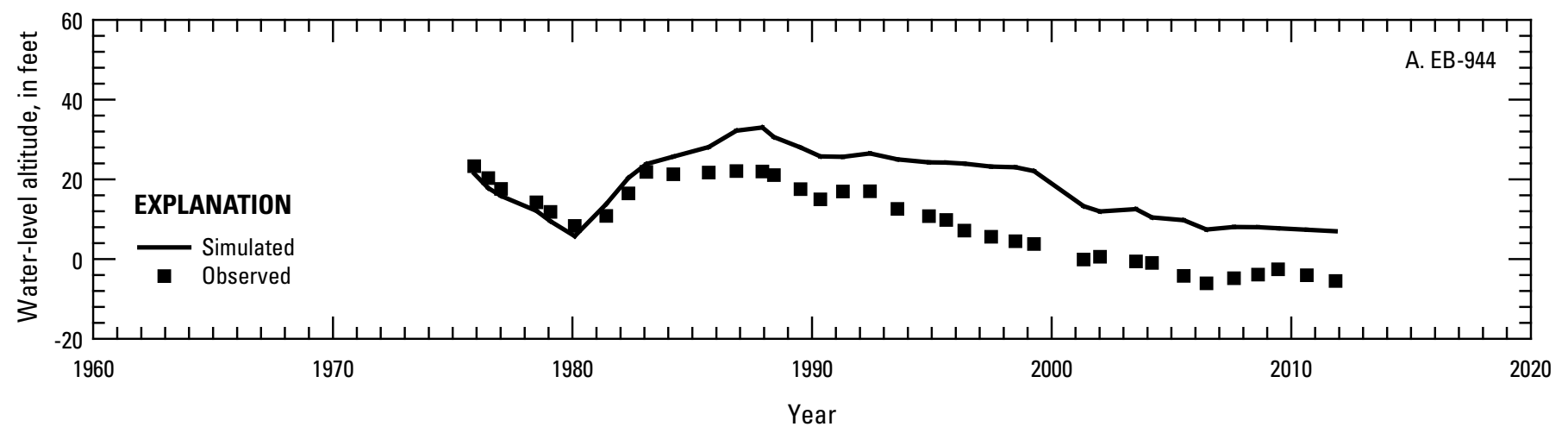

Figure 24. Graph showing simulated and observed water levels within the "2,800-foot" sand of the Baton Rouge area in southeastern Louisiana.

Table 5. Simulated steady-state and transient flow rates.

[SP, stress period; TS, time step; $\mathrm{ft}^{3} / \mathrm{d}$, cubic feet per day; Mgal/d, million gallons per day]

\begin{tabular}{lllccc}
\hline & Budget component & \multicolumn{2}{c}{ Steady-state SP 1 (pre-1940) } & \multicolumn{2}{c}{ Transient SP 69, TS 5 (Dec. 31, 2007) } \\
\hline & & \multicolumn{1}{c}{$\mathbf{f t}^{3} / \mathbf{d}$} & $\mathbf{M g a l} / \mathbf{d}$ & $\mathbf{f t}$ (t/d & $\mathbf{M g a l} / \mathbf{d}$ \\
\hline In & Specified-head layer 1 & $9.2018 \times 10^{6}$ & 68.83 & $1.5399 \times 10^{7}$ & 115.2 \\
& South row of layer 22 & $2.3632 \times 10^{5}$ & 1.77 & $7.6428 \times 10^{6}$ & 57.17 \\
& Storage & 0 & 0 & $2.5449 \times 10^{6}$ & 19.04 \\
& Multi-node wells & 0 & 0 & $2.3474 \times 10^{5}$ & 1.76 \\
\hline Out & Specified-head layer 1 & $8.9847 \times 10^{6}$ & 67.21 & $2.4214 \times 10^{6}$ & 19.23 \\
& South row of layer 22 & $4.5359 \times 10^{5}$ & 3.39 & 0 & 0 \\
& Storage & 0 & 0 & $5.2941 \times 10^{4}$ & 3.96 \\
& Multi-node wells & 0 & 0 & $2.2723 \times 10^{7}$ & 169.98 \\
\hline
\end{tabular}




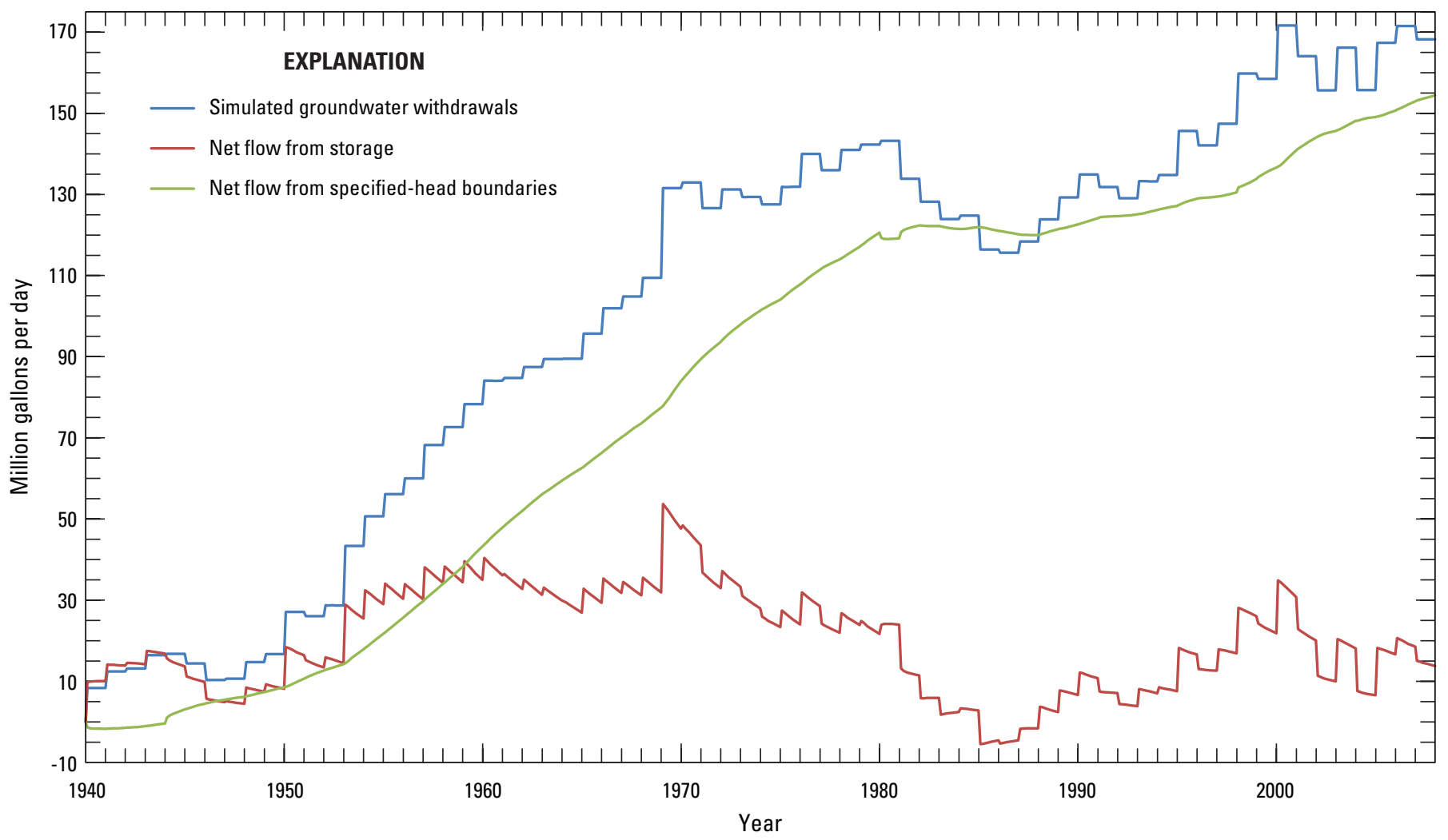

Figure 25. Graph showing simulated groundwater withdrawals and flows from storage and specified-head boundaries.

Over time, vertical hydraulic gradients caused by groundwater withdrawals from the deeper model layers cause increasing downward flow from the top model layer specified-head boundary that represents the upper aquifers. Flow from storage continues to respond to shorter term changes in the pumpage stress. Flow from specified-head boundaries is relatively smooth through time (fig. 25) because it is computed during every time step. In contrast, groundwater withdrawals are specified by stress periods composed of multiple time steps, and flow from storage responds to these specified withdrawals.

\section{Simulated Concentrations}

Because the chloride-source concentration is unknown, it was parameterized and estimated during model calibration. To facilitate calibration to observed concentrations, simulated concentrations were normalized to the source concentration. A chloride-source concentration of $10,000 \mathrm{mg} / \mathrm{L}$ produced the best overall fit of simulated-to-observed chloride concentrations. Simulated chloride concentrations at the centers of model cells containing chloride-observation well screens were used to generate the simulated chlorographs (fig. 26), the locations of which are mapped in figure 27. Wells EB-1150 and EB-630 have long screens that span more than one model layer within the "2,000-foot" sand; simulated chloride concentrations from multiple vertically adjacent model cells were averaged to calculate the simulated concentrations for these wells.

Two factors complicated simulation of the concentrations observed in observation well EB-781, the screen of which is located about $250 \mathrm{ft}$ north of the Baton Rouge Fault. First, although the precise location of the Baton Rouge Fault at the "2,000-foot" sand depth is somewhat uncertain, it was defined along the finite-difference cell interfaces nearest to its presumed location. Because the finite-difference grid cell spacing is $500 \mathrm{ft}$ in this area, the error inherent in the simulated fault location is likely on the order of $250 \mathrm{ft}$. Second, the steep, simulated concentration gradient near the north side of the Baton Rouge Fault causes a large difference in simulated concentration between the model cell north of and adjacent to the fault and its neighboring cell to the north. The concentrations simulated for the two cells north of the fault in rows 72 and 73, both in column 46 and layer 18, were averaged to generate the simulated concentration for well EB-781 (fig. 26). 

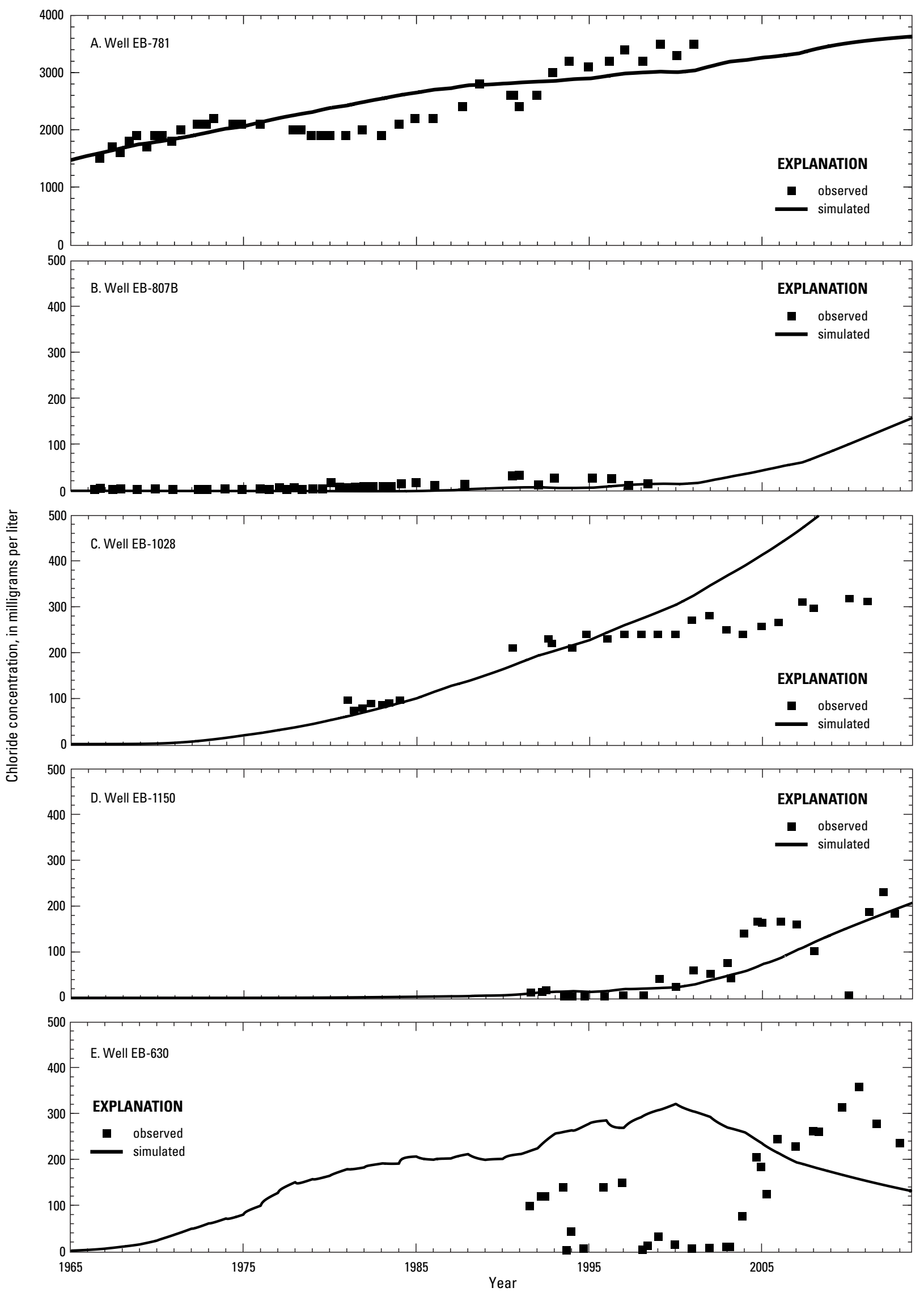

Figure 26. Graph showing simulated and observed chloride concentrations at observation wells within the "2,000-foot" sand of the Baton Rouge area in southeastern Louisiana. 


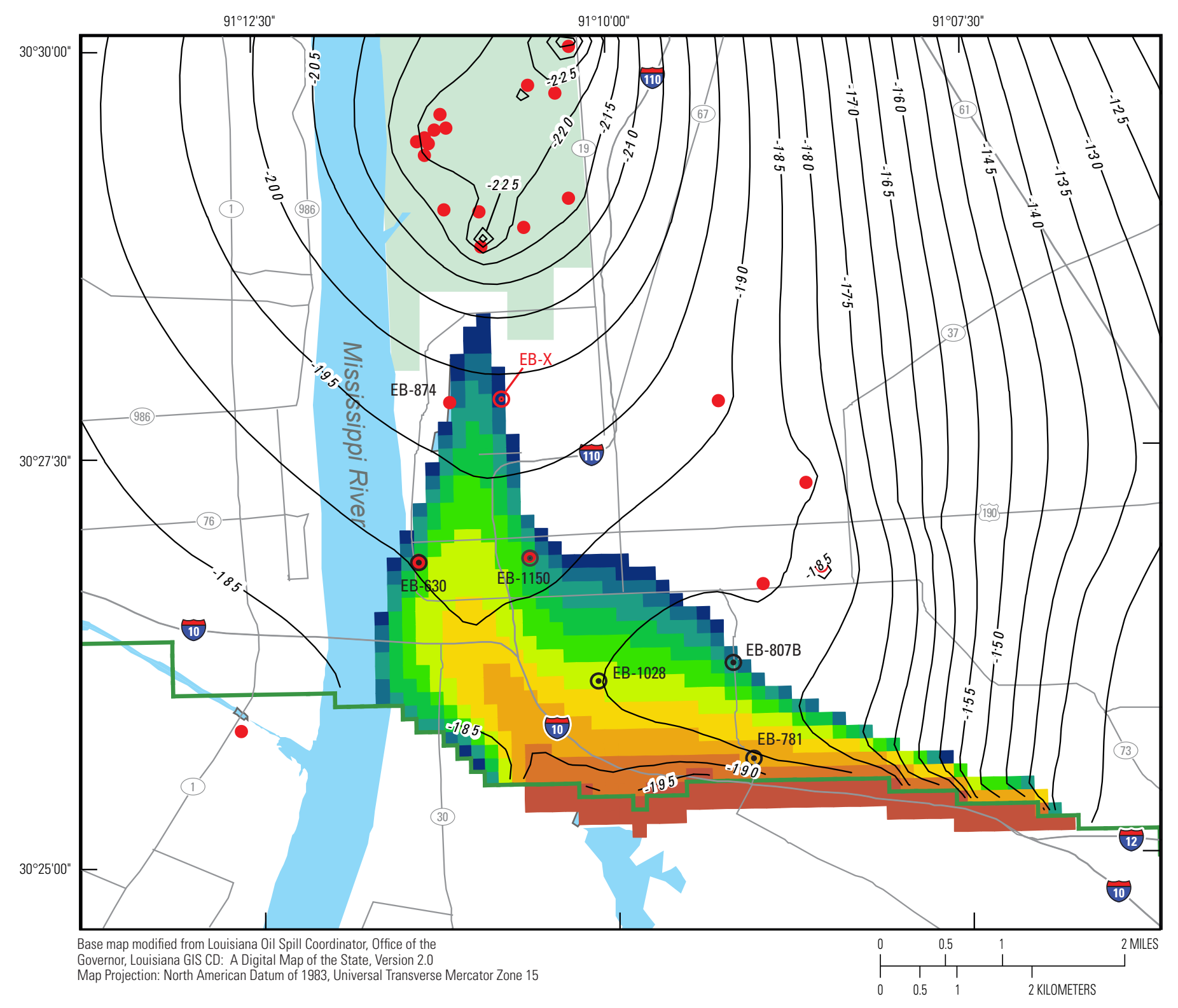

\section{EXPLANATION}

Industrial district

Simulated chloride concentration,

in milligrams per liter

$10-20$

21-40

41-80

81-160

$161-320$

$321-640$

641-1,280

$1,281-2,560$

$2,561-5,120$

5,121-10,000

Baton Rouge Fault

- -180 - Simulated water-level contour-

Shows altitude at which

water would have stood in

tightly cased wells. Contour

interval

5 feet. Datum is

National Geodetic

Vertical Datum

of 1929

- Water well screened in the

"2,000-foot" sand with pumping

simulated in the model

○ Well for which chlorograph is

EB-781 shown and well number

$\odot \quad$ Hypothetical well for which EB-X chlorograph is shown

Figure 27. Map showing simulated 2007 water levels and chloride concentrations at the base of the "2,000-foot" sand of the Baton Rouge area in the detailed model area in southeastern Louisiana. 
Although the most recent chloride concentration observation in well EB-807B (located about 0.7 mile north of well EB-871) was made in 1998, the relatively low concentrations measured before that time provide a useful constraint on model parameters affecting the transport of the saline water in a northerly direction away from source areas near EB-781 and the Baton Rouge Fault.

Chloride concentrations measured in wells EB-1150 and EB-630 (figs. 26D and 26E) have fluctuated over the period of the observation record. These fluctuations are difficult to simulate while maintaining relatively parsimonious initial and boundary conditions and transport-model parameter distributions. Consequently, simulated chlorographs for these wells are a reasonable fit to intermediate values within the range of fluctuations in the observed concentrations.

\section{Limitations and Appropriate Use of the Model}

The groundwater model was designed and calibrated primarily to simulate groundwater flow in the "1,500-foot" sand and "2,000-foot" sand and saltwater transport within the "2,000-foot" sand of the Baton Rouge area. Because the model layering was designed to represent the most important hydrogeologic units of the aquifer system and water-level observations from all aquifers in the Baton Rouge area were used for model calibration, groundwater flow within the "1,000-foot" sand and "1,200-foot" sand, "1,500-foot" sand, "1,700-foot" sand, "2,400-foot" sand, and "2,800-foot" sand is reasonably well simulated. It is possible to simulate the effects of future changes in groundwater withdrawals on groundwater levels in each of these sands in the Baton Rouge area. Predictions of changes in water levels in the "1,500foot" sand and "2,000-foot" sand that might result from changes such as those described in the subsequent section on hypothetical groundwater management scenarios are examples of appropriate uses of the model. The period before 1940 was simulated with a steady-state solution of the flow equation, during which transient effects of any minor groundwater withdrawals were not simulated.

Chloride concentrations within the "2,000-foot" sand in the Baton Rouge area were used to calibrate the model; consequently, saltwater encroachment in other aquifers in the Baton Rouge area is not accurately simulated. Predictions of changes in chloride concentrations within the " 2,000 -foot" sand that might result from changes such as those described in the subsequent section on hypothetical groundwater management scenarios is an appropriate use of the model. Predictions of changes in chloride concentrations within the "1,500-foot" sand or other aquifers are not appropriate because the model was not calibrated to chloride-concentration observations within other aquifers.

The variably spaced, finite-difference model grid enabled fine discretization with greater numerical accuracy in the
Baton Rouge area and coarse and large aspect-ratio (long side divided by short side) with less numerical accuracy in the surrounding areas. Water levels predicted for areas with either very coarse or very large aspect-ratio model cells will be less accurate and should be used judiciously.

\section{Hypothetical Groundwater- management Scenarios}

Six hypothetical groundwater-management scenarios were formulated to predict the effects of modifying groundwater withdrawals on future groundwater levels and saltwater concentrations. All of the scenarios used the 2007 groundwater-withdrawal rate for the 7-year period from 2008 through 2014. As previously discussed, simulated 2007 withdrawal rates totaled $169 \mathrm{Mgal} / \mathrm{d}$ after layer 1 withdrawals were excluded. Simulated 2007 withdrawals from layer 5 north of the fault were $27.5 \mathrm{Mgal} / \mathrm{d}$ and included $23.7 \mathrm{Mgal} / \mathrm{d}$ from the "1,500-foot" sand. Simulated 2007 withdrawals from layers 9 through 18 north of the fault were $30.2 \mathrm{Mgal} / \mathrm{d}$ and included 25.3 Mgal/d from the "2,000-foot" sand. Of the 25.3 $\mathrm{Mgal} / \mathrm{d}$ withdrawn from the "2,000-foot" sand, $16.6 \mathrm{Mgal} / \mathrm{d}$ were withdrawn in the industrial district. Scenario 1 simulates continuation of the 2007 pumping rate through 2047 and is a benchmark for comparison of water levels and (or) chloride concentrations simulated in the other five scenarios. Scenario 2 simulated the effect of reducing groundwater withdrawals from seven selected industrial wells by $10.8 \mathrm{Mgal} / \mathrm{d}$ beginning in 2015 on water levels in the " 1,500 -foot" sand. Scenarios $3,4,5$, and 6 simulate alternative strategies for mitigating the northward migration of saltwater within the "2,000-foot" sand. Scenarios $3 \mathrm{a}$ and $3 \mathrm{~b}$ simulate a $2.0 \mathrm{Mgal} / \mathrm{d}$ withdrawal from a scavenger well beginning in 2017 at the base of the "2,000foot" sand, scenario 4 simulates a $3.6 \mathrm{Mgal} / \mathrm{d}$ reduction in withdrawals from the "2,000-foot" sand at selected industrial wells beginning in 2015, and scenario 5 simulates cessation of withdrawals from the "2,000-foot" sand within the industrial district beginning in $2015(16.625 \mathrm{Mgal} / \mathrm{d}$ reduction in withdrawals). Scenario 6 simulates the combined effect of a $1.375 \mathrm{Mgal} / \mathrm{d}$ reduction in withdrawals from the " 2,000 -foot" sand in 2015 with a $2.5 \mathrm{Mgal} / \mathrm{d}$ withdrawal from a "scavenger well couple" accompanied by a $1.5 \mathrm{Mgal} / \mathrm{d}$ reduction in withdrawals from public-supply wells beginning in 2017.

In addition to the existing observation wells, the chloride concentration at hypothetical observation well "EB-X," located south of the industrial district (fig. 27), is simulated for each scenario. The "plume area," defined as an area with a simulated chloride concentration greater than $10 \mathrm{mg} / \mathrm{L}$ in model layer 18 (the base of the "2,000-foot" sand) north of the Baton Rouge Fault, and the mean and median cell concentrations within that area in 2047 for each scenario as well as 2007 are summarized in table 6. 
Table 6. Simulated plume areas and chloride concentrations.

[mg/L, milligrams per liter]

\begin{tabular}{lccc}
\hline \multicolumn{1}{c}{ Date and/or scenario } & $\begin{array}{c}\text { Plume area } \\
\text { (square miles) }\end{array}$ & $\begin{array}{c}\text { Mean layer 18 cell } \\
\text { concentration (mg/L) }\end{array}$ & $\begin{array}{c}\text { median layer 18 cell } \\
\text { concentration (mg/L) }\end{array}$ \\
\hline 2007: & 5.42 & 883 & 340 \\
2047: scenario 1 & 7.17 & 958 & 311 \\
2047: scenario 3a: & 6.01 & 1,023 & 362 \\
2047: scenario 3b: & 5.61 & 765 & 138 \\
2047: scenario 4 & 7.20 & 954 & 308 \\
2047: scenario 5 & 6.54 & 755 & 216 \\
2047: scenario 6 & 5.25 & 730 & 130 \\
\hline
\end{tabular}

\section{Scenario 1: Continued Groundwater Withdrawals at 2007 Rates}

Continuation of the "status quo" groundwater withdrawals was simulated by using the simulated 2007 withdrawal rates for an additional 40 years (2008-47). Contours of predicted water-levels within the "1,500-foot" sand (fig. 28) for 2047 are similar to those simulated for 2007 (fig. $17 A, B$ ) but are consistently about $5 \mathrm{ft}$ lower throughout the Baton Rouge area. The lowest water-level altitudes of about $-140 \mathrm{ft}$ are simulated $1.6 \mathrm{mi}$ north-northwest of observation well EB-1293.

Continued groundwater withdrawals at 2007 rates are predicted to cause further decline of groundwater levels within the "2,000-foot" sand. Although the shape of contours of predicted water levels within the "2,000-foot" sand (fig. 29) for 2047 are similar to those for 2007 (figs. 18A,B), the water levels are about $13 \mathrm{ft}$ lower in the Baton Rouge area. The lowest water-level altitudes of about $-245 \mathrm{ft}$ are simulated in the industrial district.

Comparison of the simulated chloride concentration distributions in layer 18 for years 2047 (fig. 29) and 2007 (fig. 27 ) indicates that the portion of the saltwater plume containing chloride concentrations in the $161-320 \mathrm{mg} / \mathrm{L}$ range at the base of the "2,000-foot" sand would migrate approximately $0.6 \mathrm{mi}$ northward toward the industrial district. The plume area at the base of the "2,000-foot" sand north of the Baton Rouge Fault with concentrations above background levels $(10 \mathrm{mg} / \mathrm{L})$ would increase by about 32 percent (table 6). Concentrations at most existing observation wells would increase, and the concentration at EB-X, near the center of the plume south of the industrial district (fig. 29), is predicted to increase from about $20 \mathrm{mg} / \mathrm{L}$ to about $180 \mathrm{mg} / \mathrm{L}$ within about 30 years (fig. $30 F$ ). Concentrations at observation well EB-630 are predicted to decrease because groundwater flow at that location is from the south where the aquifer south of the fault may be fresh and the saltwater source is not simulated.

\section{Scenario 2: Reduction of Groundwater Withdrawals from the "1,500-foot" Sand}

Saltwater encroachment is also a concern within the "1,500-foot" sand in the Baton Rouge area. Similar to the saltwater encroachment problem within the " 2,000 -foot" sand, this encroachment is caused by water-level drawdown that is due to withdrawals from the "1,500-foot" sand. Although chloride concentrations within the "1,500-foot" sand were not calibrated, simulation of transient water levels within the "1,500-foot" sand enabled assessment of a possible groundwater-withdrawal reduction on water levels in the "1,500-foot" sand. Of particular interest is the contribution to future water-level drawdown in the "1,500-foot" sand caused by withdrawals from selected industrial wells in the northwest corner of East Baton Rouge Parish (fig. 11). This contribution was assessed as the difference between the 2047 water levels simulated with scenario 1 and the 2047 water levels simulated with the selected industrial wells turned off from 2015 through 2047. For scenario 2, zero withdrawal rates were specified from seven industrial wells in model row 10 and column 10 (fig. 10) that have screens either in the "1,500-foot" sand or an adjacent sand, simulating a withdrawal reduction of 10.8 Mgal/d. Two wells (EB-963 and PC-343) have simulated screen intervals only within the "1,500-foot" sand. Four wells (EB-835, EB-837, EB-1248, and EB-1277) have simulated screen intervals within both the "1,500-foot" sand and the "1,700-foot" sand. The remaining well (EB-838) is screened entirely within the " 1,700 -foot" sand.

Comparison of the contours of water levels predicted for 2047 within the "1,500-foot" sand for scenarios 1 and 2 (figs. 28 and 31) indicated that 2047 water-level altitudes for scenario 2 are generally about 10 to $12 \mathrm{ft}$ higher in the Baton Rouge area than those predicted for scenario 1 . The lowest predicted water-level altitudes of about $-125 \mathrm{ft}$ are around municipal supply wells located about 2 mi southeast of the industrial district. 


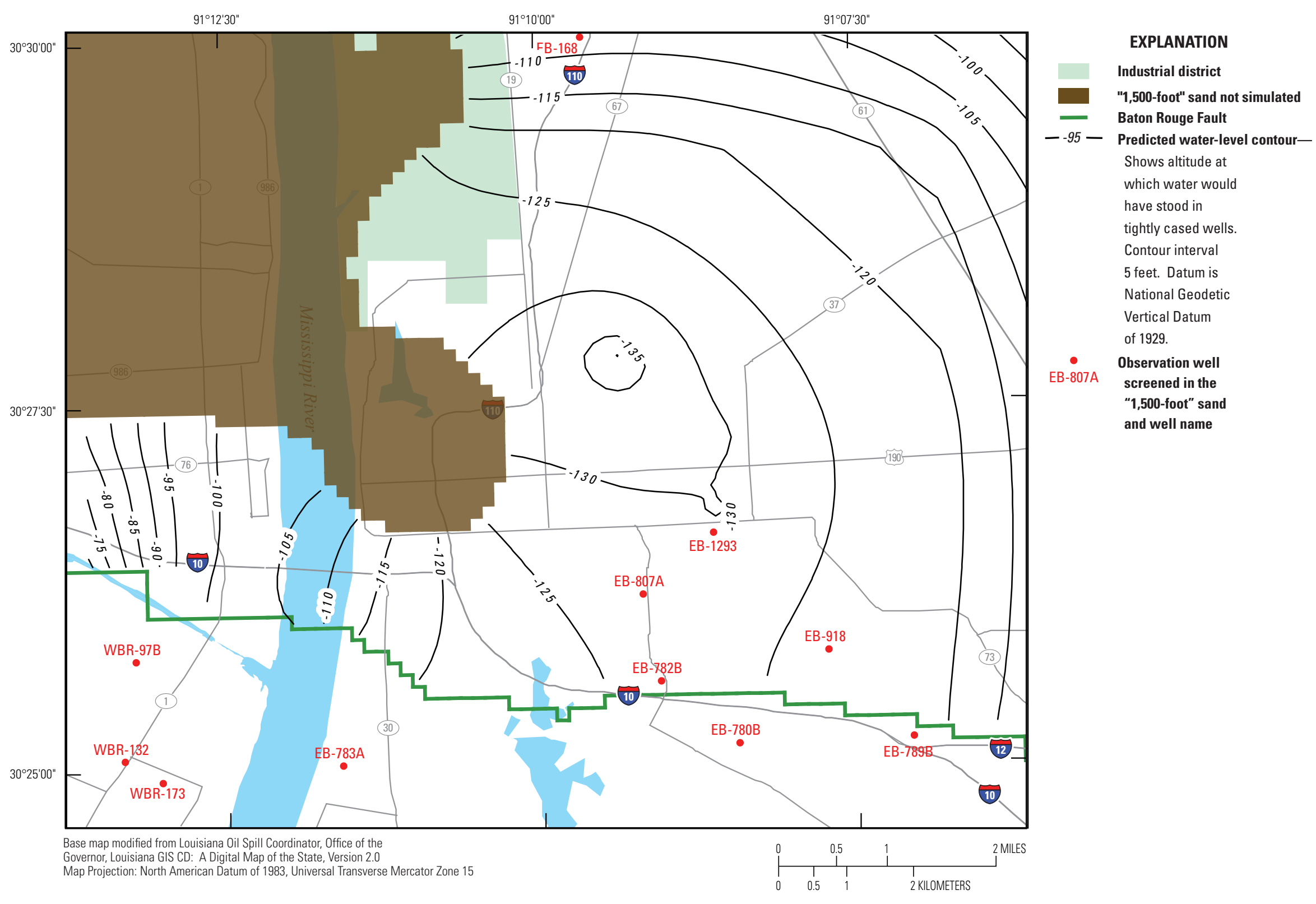

Figure 28. Map showing predicted 2047 water levels within the "1,500-foot" sand of the Baton Rouge area in the detailed model area in southeastern Louisiana after continued pumping at 2007 rates (scenario 1). 


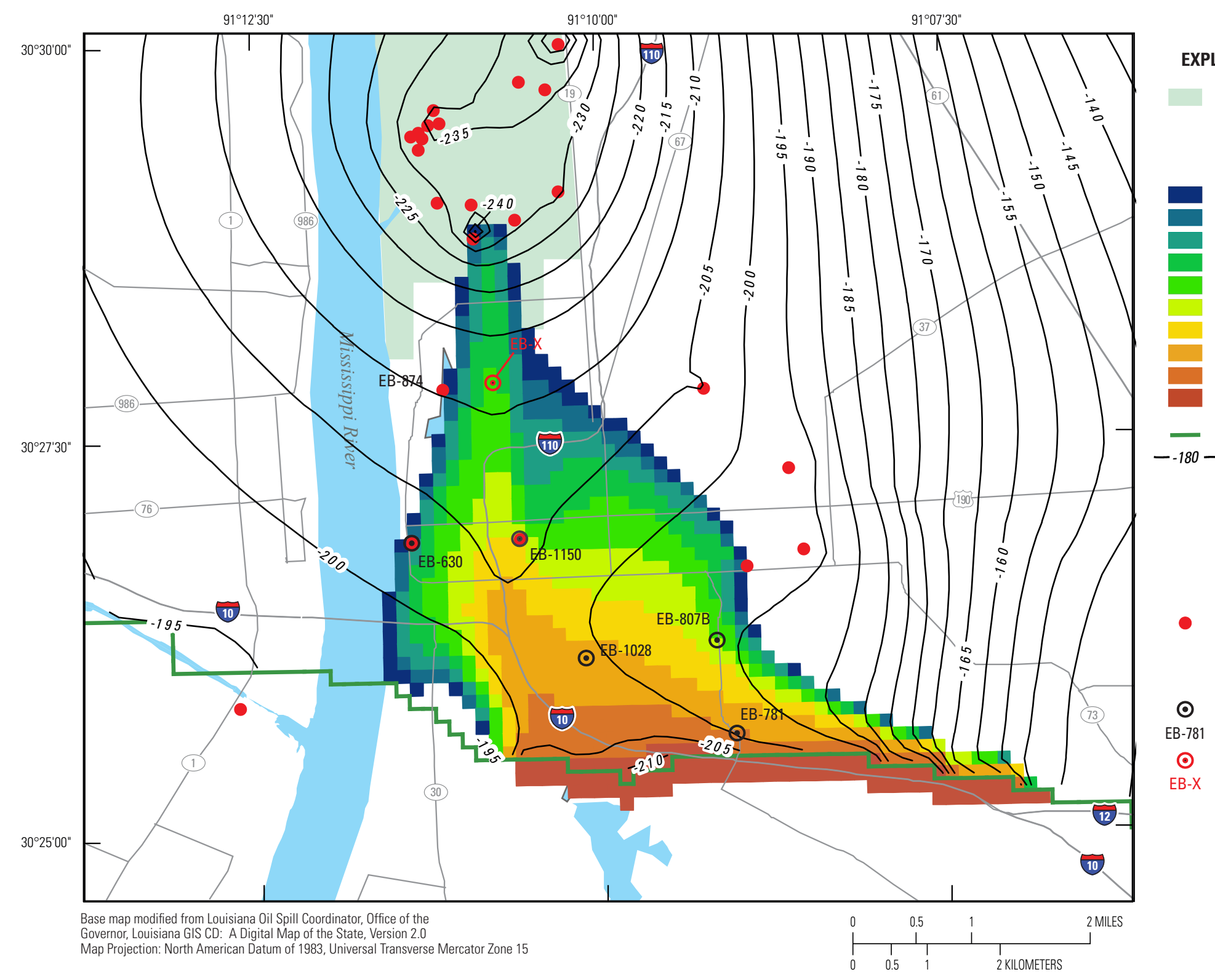

EXPLANATION

Industrial district

Predicted chloride

concentration, in

milligrams per liter

10-20

41-80

81-160

$161-320$

321-640

641-1,280

$1,281-2,560$

2,561-5, 120

$5,121-10,000$

Baton Rouge Fault

Predicted water-level contour-

Shows altitude at which

water would have stood in

tightly cased wells. Contour

interval 5 feet. Datum is

National Geodetic Vertical

Datum of 1929

- Water well screened

in the "2,000-foot"

sand with pumping

simulated in the model

Well for which chlorograph is

shown and well number

Hypothetical well for which

chlorograph is shown

Figure 29. Map showing predicted 2047 water levels and chloride concentrations at the base of the "2,000-foot" sand of the Baton Rouge area in the detailed model area in southeastern Louisiana after continued pumping at 2007 rates (scenario 1). 

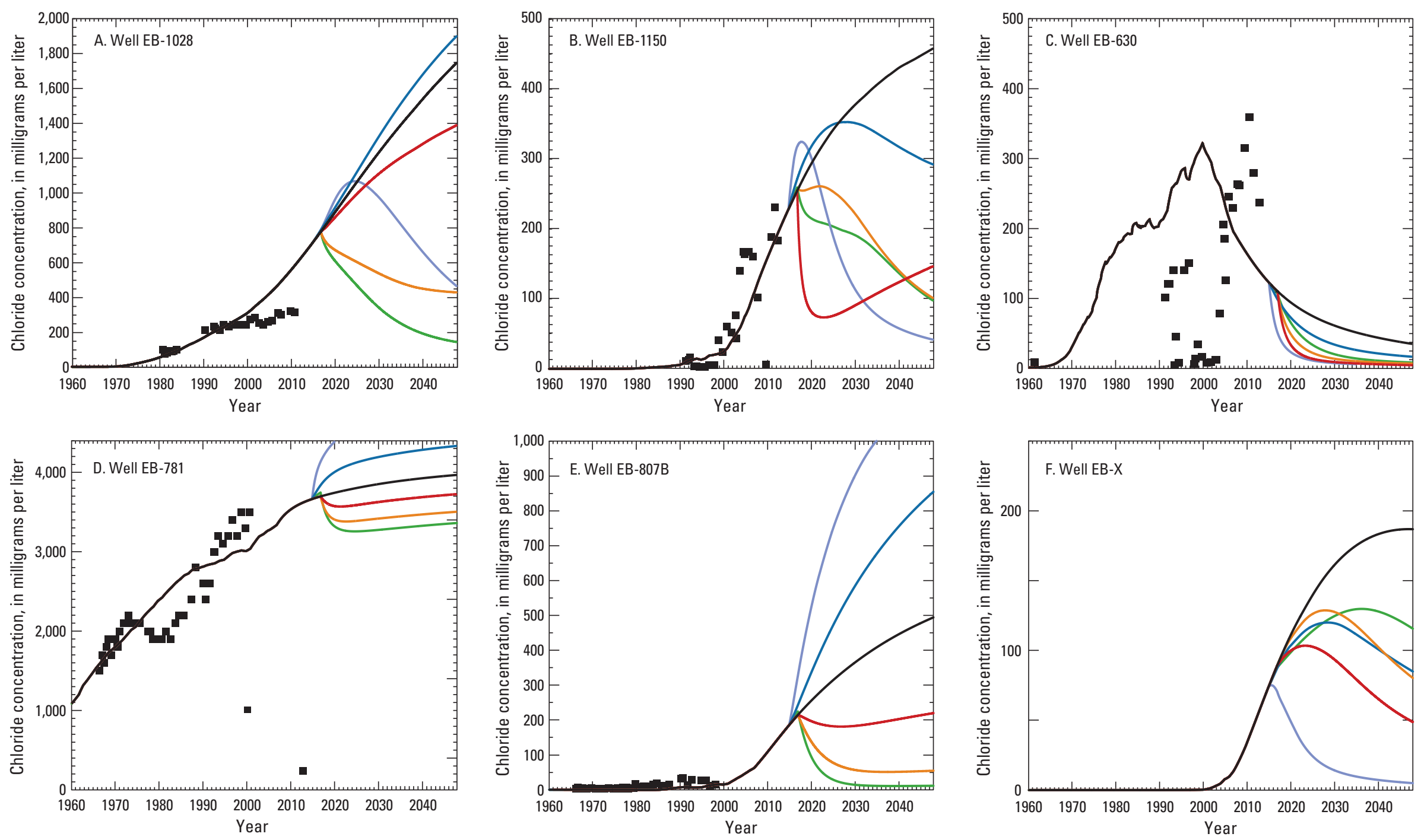

\section{EXPLANATION}

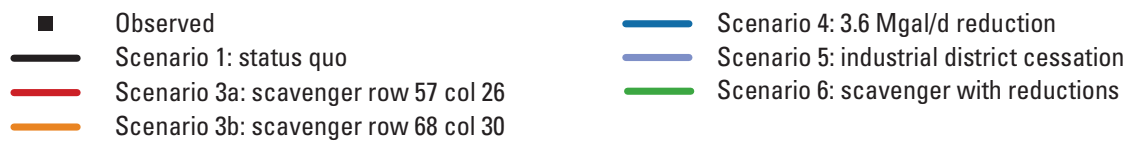

Figure 30. Graphs showing predicted chloride concentrations at the base of the "2,000-foot" sand after continued pumping at 2007 rates (scenario 1), installation of a scavenger well (scenario $3 \mathrm{a}, \mathrm{b}$ ), industrial district withdrawal reduction of 3.6 million gallons per day (Mgal/d) (scenario 4), cessation of industrial district withdrawals from the "2,000-foot" sand (scenario 5), and a scavenger well with withdrawal reductions (scenario 6) for: $A$, well EB-1028; $B$, well EB-1150; $C$, well EB-630; $D$, well EB-781; E, well EB-807B; and $F$, hypothetical well EB-X. 


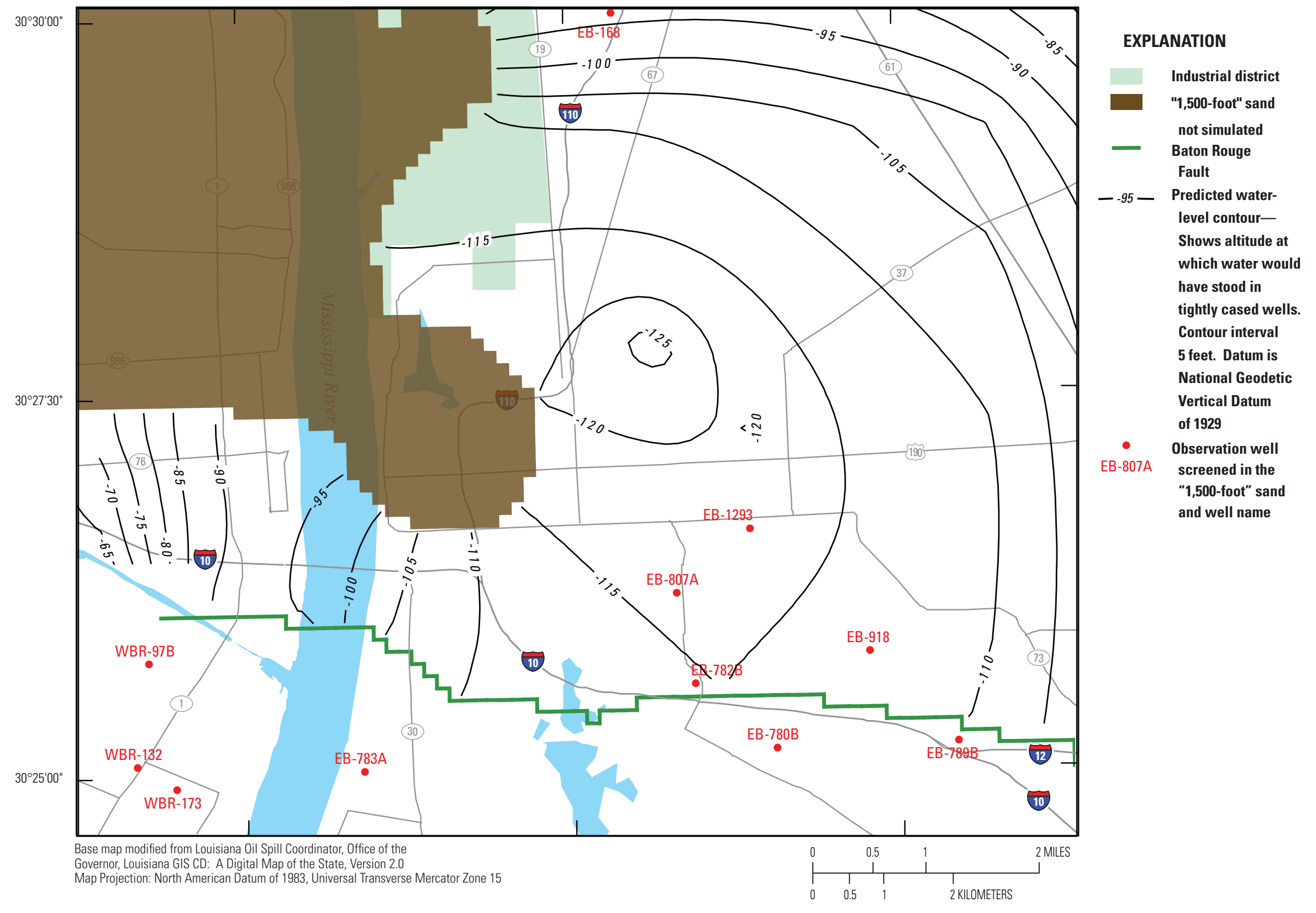

Figure 31. Map showing predicted 2047 water levels within the "1,500-foot" sand of the Baton Rouge area in the detailed model area in southeastern Louisiana following cessation of pumping from selected industrial wells in the "1,500-foot" and "1,700-foot" sands beginning in 2015 (scenario 2). 


\section{Scenario 3: Scavenger Well Withdrawal from the Base of the "2,000-foot" Sand}

One proposed strategy to mitigate the northward migration of the saltwater plume is the installation and operation of a "scavenger" well that is screened at the base of the "2,000-foot" sand, where multidepth observations of chloride concentrations within the aquifer have indicated that higher concentrations exist (Tomaszewski, 1996). The scavenger well would withdraw the higher-concentration groundwater from the base of the aquifer, which would subsequently require desalinization and (or) disposal. For scenario 3, the effects of pumping $2.0 \mathrm{Mgal} / \mathrm{d}$ from the bottom (layer 18) of the "2,000-foot" sand on water levels and chloride concentrations were simulated for two possible scavenger well locations. In scenario 3, total simulated withdrawals from the "2,000-foot" sand north of the fault remained at $25.3 \mathrm{Mgal} / \mathrm{d}$ during 2007-16 but increased to 27.3 Mgal/d during 2017-47. The effects of scavenger well activation in 2017 at each location was simulated separately.

Because of the additional $2 \mathrm{Mgal} / \mathrm{d}$ withdrawal from the scavenger well, water-levels simulated for 2047 in the "2,000foot" sand for both scavenger well locations are generally about 10 to $15 \mathrm{ft}$ lower than those predicted for scenario 1 (the "status quo" simulation), and the lowest water-levels are predicted in the same locations of the industrial district as in scenario 1 (figs. 32 and 33). Water-level contours depict the drawdown around each of the scavenger wells, where 2047 water-level altitudes of about $-260 \mathrm{ft}$ are simulated.

For scenario $3 \mathrm{a}$, the scavenger well was simulated in model row 57, column 26 (fig. 32). Predicted 2047 chloride concentrations in layer 18 (the base of the "2,000-foot" sand) indicate that although the lowest-concentration front of the saltwater plume continues to migrate northward toward the industrial district, the concentrations between the scavenger well and the industrial district are lower than in scenario 1 (fig. 27). Higher chloride concentrations within the central portion of the plume between the scavenger well and the Baton Rouge Fault might result from more movement of saltwater because of the larger hydraulic gradients generated by the $2 \mathrm{Mgal} / \mathrm{d}$ withdrawal from the scavenger well.

For scenario $3 \mathrm{~b}$, a scavenger well was simulated in model row 68, column 30 (fig. 33). Predicted 2047 chloride concentrations in layer 18 indicate that the saltwater plume would also continue to migrate northward toward withdrawal wells in the industrial district with concentrations lower than in scenario 1. Predicted chloride concentration within the central portion of the plume between this scavenger well location and observation wells EB-630 and EB-1150 are lower than those predicted for either scenario 1 or scenario $3 a$ (the other scavenger well location).

In comparison to the concentrations simulated in scenario 1, operation of the scavenger well in the locations specified in scenarios $3 \mathrm{a}$ and $3 \mathrm{~b}$ reduces the chloride concentrations at all existing chloride-observation well locations (fig. 30). At EB-X, the hypothetical observation location near the leading-edge of the plume, predicted 2047 chloride concentrations decrease from the $187 \mathrm{mg} / \mathrm{L}$ predicted in scenario 1 to $50 \mathrm{mg} / \mathrm{L}$ and $80 \mathrm{mg} / \mathrm{L}$ for scenarios $3 \mathrm{a}$ and $3 \mathrm{~b}$, respectively (fig. 30F).

\section{Scenario 4: Reduction of Groundwater Withdrawals from the "2,000-foot" Sand in the Baton Rouge Industrial District}

Reduction of groundwater withdrawals from the " 2,000 foot" sand in the Baton Rouge industrial district would decrease the hydraulic gradient toward that area and limit the northward advective transport of saltwater. A reduction of 3.6 $\mathrm{Mgal} / \mathrm{d}$ from selected wells screened in the "2,000-foot" sand in the industrial district was simulated beginning in 2015. In scenario 4, total simulated withdrawals from the " 2,000 foot" sand north of the fault remained at $25.3 \mathrm{Mgal} / \mathrm{d}$ during 2007-14 but decreased to $21.7 \mathrm{Mgal} / \mathrm{d}$ during 2015-47.

Contours of water levels predicted within the "2,000foot" sand (fig. 34) for 2047 illustrate similar groundwater flow to that predicted for scenario 1 but are generally between 20 and $35 \mathrm{ft}$ higher in the Baton Rouge area. The lowest waterlevel altitude of about $-215 \mathrm{ft}$ is predicted within the industrial district in the same location as that predicted for scenario 1.

The map of simulated chloride concentrations for 2047 at the base of the "2,000-foot" sand (fig. 34) indicates that although the saltwater plume would continue to migrate northward toward the industrial district withdrawal wells following a $3.6 \mathrm{Mgal} / \mathrm{d}$ withdrawal reduction, concentrations in the leading portion of the plume would be lower. The simulated concentration at EB-X is $85 \mathrm{mg} / \mathrm{L}$ (fig. $30 F$ ), which is less than half of the concentration predicted for scenario 1. In contrast, concentrations at observation wells EB-1028 and EB-807B increase with respect to scenario 1 because decreased flow toward the industrial district results in relatively more flow toward the area of municipal withdrawals $1 \mathrm{mi}$ north of EB-807B. The area with a chloride concentration greater than $10 \mathrm{mg} / \mathrm{L}$ is similar to that predicted in scenario 1 , as are the median and mean plume concentrations (table 6).

\section{Scenario 5: Cessation of Groundwater Withdrawals from the "2,000-foot" Sand in the Baton Rouge Industrial District}

Zero withdrawals from all 19 production wells screened in the "2,000-foot" sand in the industrial district (fig. 9) were specified beginning in 2015 to simulate cessation of withdrawals in the industrial district. In scenario 5 , total simulated withdrawals from the "2,000-foot" sand north of the fault remained at $25.3 \mathrm{Mgal} / \mathrm{d}$ during $2007-14$ but were reduced by $16.6 \mathrm{Mgal} / \mathrm{d}$ to $8.7 \mathrm{Mgal} / \mathrm{d}$ during 2015-47. In comparison to scenario 1 , this scenario simulated the largest increase in water levels and change in chloride concentrations within the "2,000-foot" sand. The simulated 2047 water-level 


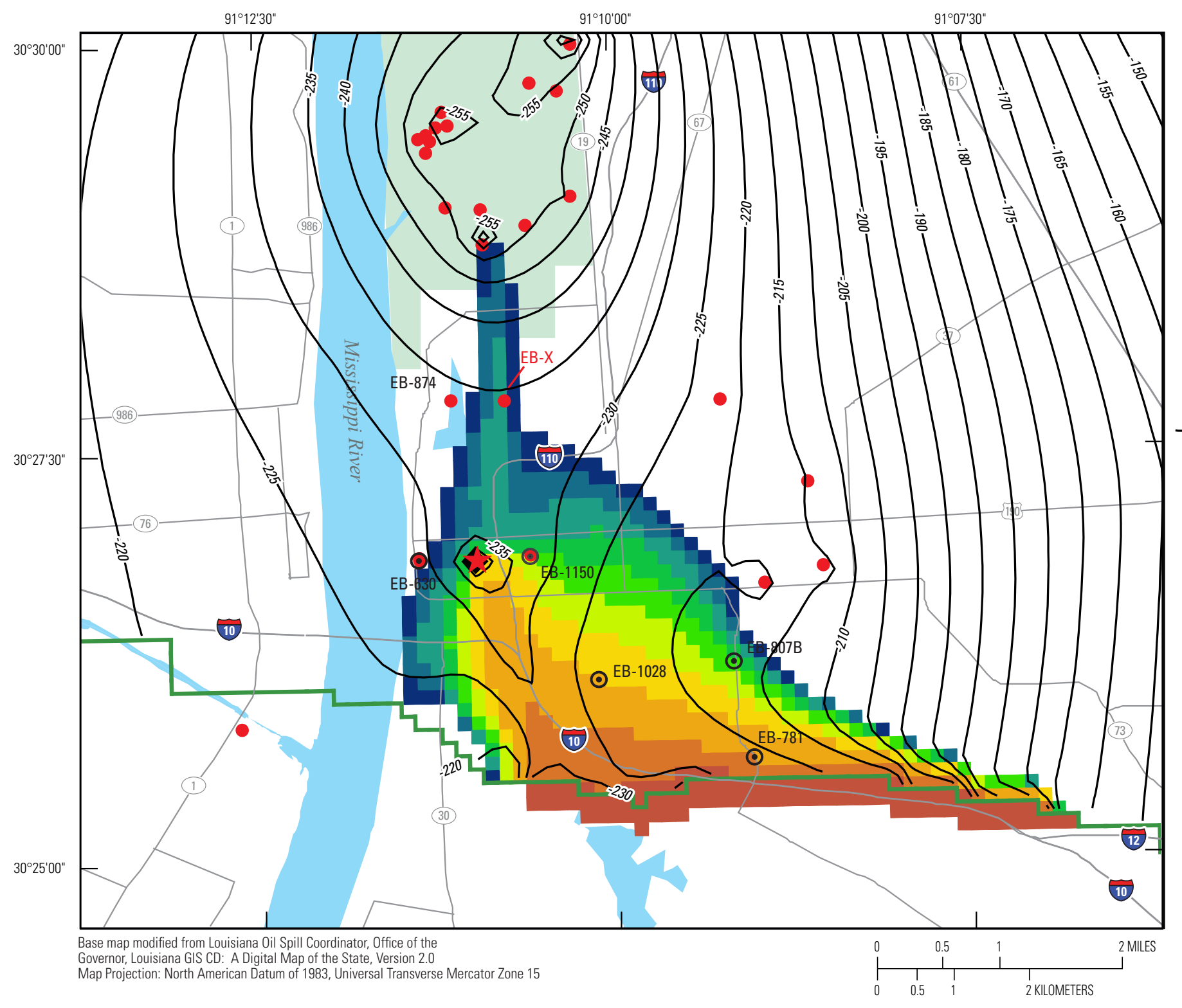

\section{EXPLANATION}

Industrial district

Predicted chloride concentration

in milligrams per liter

10-20

21-40

41-80

81-160

161-320

$321-640$

641-1,280

$1,281-2,560$

2,561-5,120

$5,121-10,000$

\section{Baton Rouge Fault}

-180 - Predicted water-level contourShows altitude at which water

would have stood in tightly

cased wells. Contour interval

5 feet. Datum is National Geodetic

Vertical Datum of 1929

- Water well screened in the

"2,000-foot" sand with pumping simulated in the model

- Well for which chlorograph is

EB-781

shown and well number

○ Hypothetical well for which

EB-X chlorograph is shown

Scavenger well screened at the

base of the "2,000-foot" sand

Figure 32. Map showing predicted 2047 water levels and chloride concentrations at the base of the "2,000-foot" sand of the Baton Rouge area in the detailed model area in

southeastern Louisiana after pumping at a rate of 2 million gallons per day from a simulated scavenger well located in model row 57 and column 26 beginning in 2017 (scenario 3 ). 


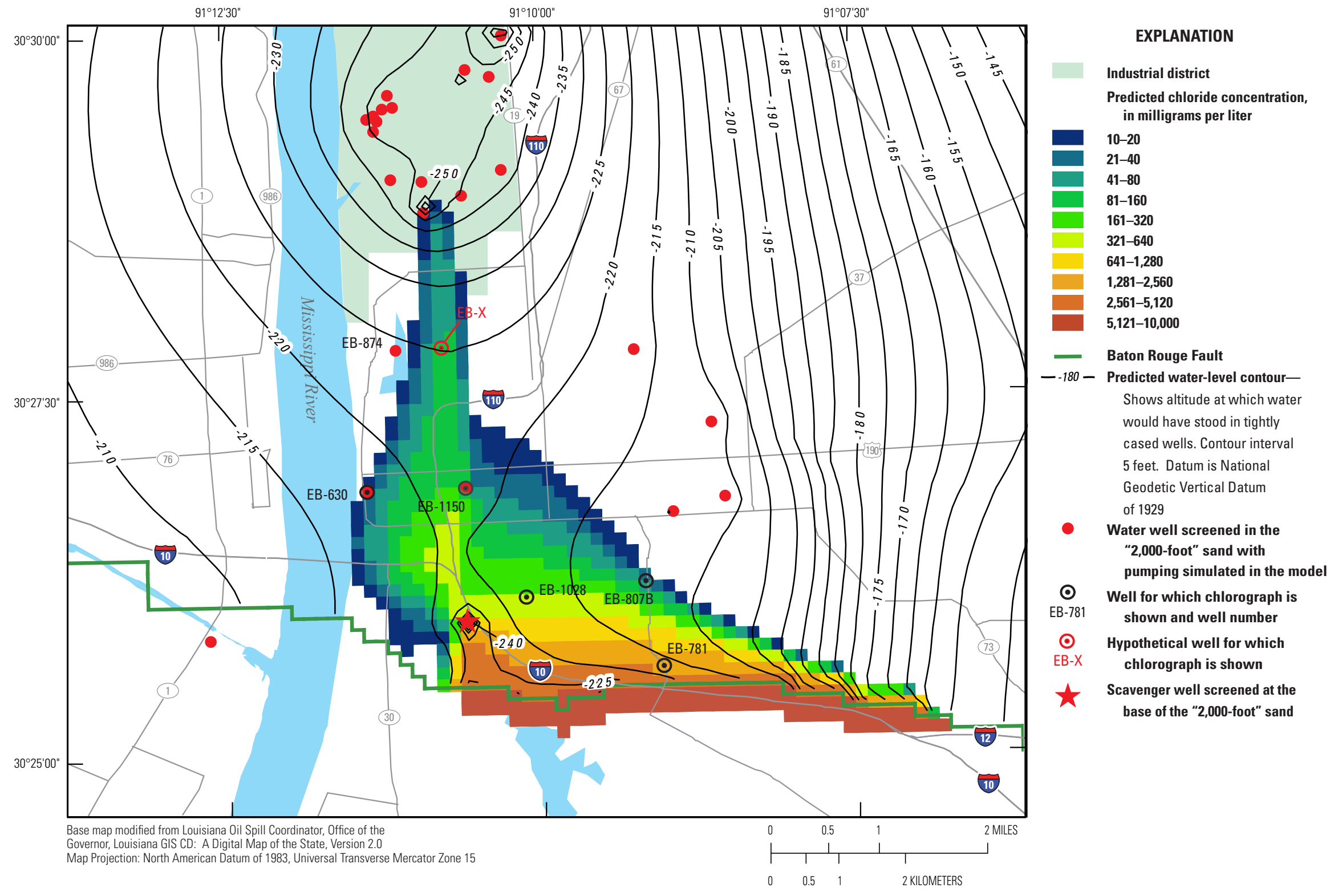

Figure 33. Map showing predicted 2047 water levels and chloride concentrations at the base of the "2,000-foot" sand of the Baton Rouge area in the detailed model area in southeastern Louisiana after pumping at a rate of 2 million gallons per day from a simulated scavenger well located in model row 68 and column 30 starting in 2017 (scenario 3 ). 


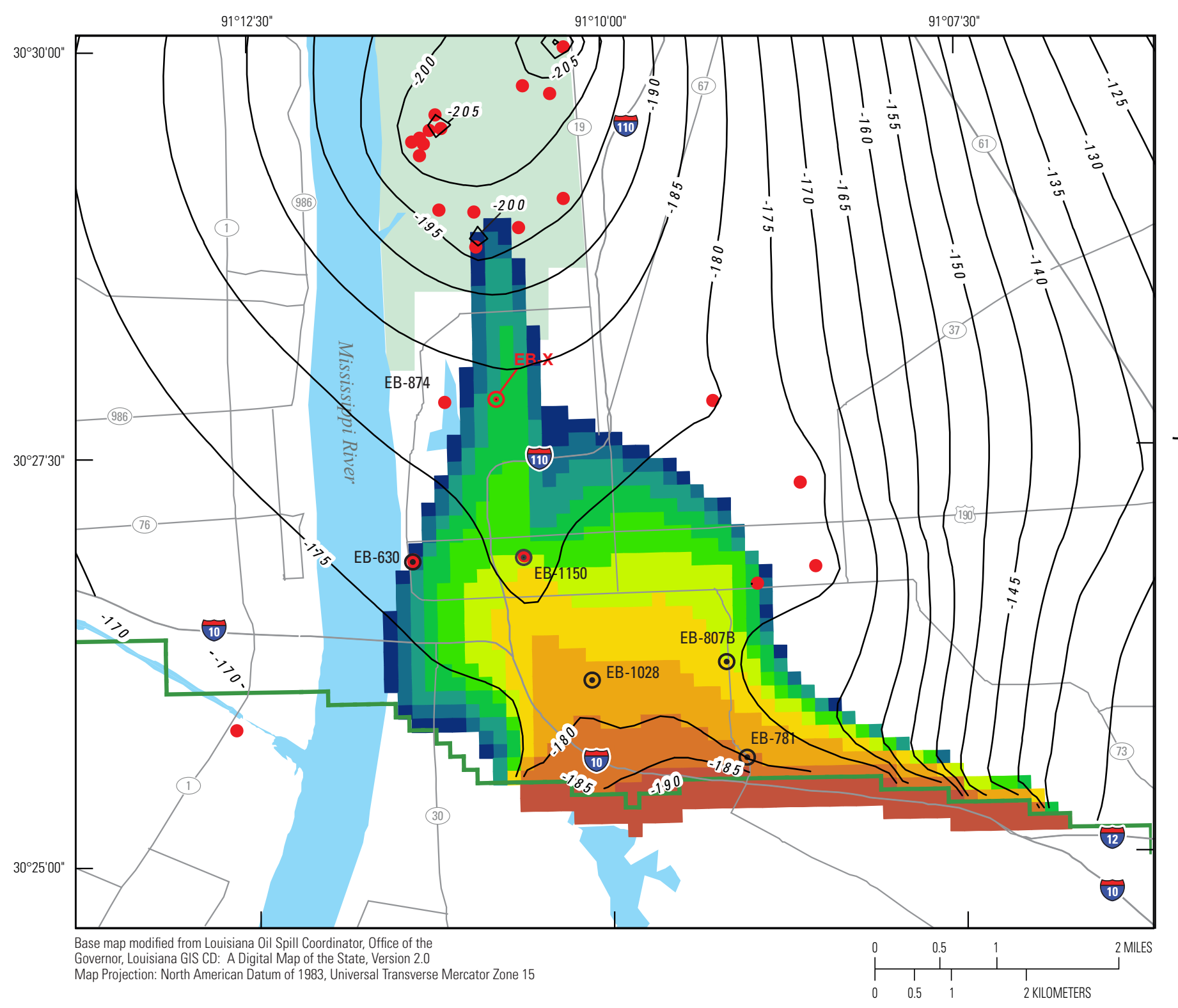

\section{EXPLANATION}

Industrial district

Predicted chloride oncentration

in milligrams per liter

난 20

21-40

41-80

81-160

$161-320$

321-640

641-1,280

$1,281-2,560$

2,561-5,120

$5,121-10,000$

Baton Rouge Fault

- 180 - Predicted water-level contour-

Shows altitude at which water

would have stood in tightly

cased wells. Contour interval

5 feet. Datum is National Geodetic

Vertical Datum of 1929

- Water well screened in the "2,000-foot" sand with pumping

simulated in the model

○ Well for which chlorograph is

EB-781 shown and well number

○ Hypothetical well for which

EB-X chlorograph is shown

Figure 34. Map showing predicted 2047 water levels and chloride concentrations at the base of the "2,000-foot" sand of the Baton Rouge area in the detailed model area in southeastern Louisiana after a 3.6 million gallon per day reduction in pumping (from 2007 rates) at selected wells in the Baton Rouge industrial district beginning in 2015

(scenario 4). 
altitudes within the "2,000-foot" sand (fig. 35) are 95 to $165 \mathrm{ft}$ higher than those in scenario 1, and the direction of groundwater flow in the Baton Rouge area differs. In scenarios 1 through 4, groundwater flow in the "2,000-foot" sand is generally toward the area of water-level drawdown under the industrial district, whereas in scenario 5, groundwater flows toward an area of water-level drawdown about $0.5 \mathrm{mi}$ north of EB-807B (fig. 35). Minimum groundwater levels of about $-114 \mathrm{ft}$ reflect the continued municipal withdrawals from the "2,000-foot" sand in this area.

The simulated chloride-concentration distribution (fig. 35 ) in this scenario reflects the change in groundwater-flow direction. Although some saltwater would continue to cross the Baton Rouge Fault and encroach toward municipal supply wells in the area of drawdown about 0.5 mi north of EB-807B, further encroachment toward the industrial district would be abated. Saltwater within the "2,000-foot" sand that is presently encroaching south of the industrial district (fig. 27) would be replaced by freshwater flowing from the northwest. The simulated chloride concentration at the base of the "2,000-foot" sand at EB-X decreases to "background concentrations" below $10 \mathrm{mg} / \mathrm{L}$ by 2047 (fig. 30F). Because saltwater is no longer transported toward the industrial district in this scenario, relatively more of it is transported toward the area of municipal groundwater withdrawals north of EB-807B. Consequently, the simulated chloride concentration at well EB-807B is about twice that simulated in scenario 1. Simulated chloride concentrations at EB-1028 and EB-1150 initially increase as higher-concentration water west of those observation wells begins to flow eastward but subsequently decline as it is replaced by fresher water from west of the plume. Concentrations simulated in well EB-781 remain similar to the other scenarios because it is close to the salt source where concentrations are less sensitive to the simulated pumping distribution.

\section{Scenario 6: Scavenger Well Combined with a Reduction of 1.375 Million Gallons Per Day of Industrial District Withdrawal from the " 2,000 - foot" Sand}

Analysis of the preceding scenarios suggested an additional scenario in which industrial district withdrawal reductions from the "2,000-foot" sand beginning in 2015 are combined with the activation of a "scavenger well couple" in 2017 at the location simulated in scenario $3 \mathrm{~b}$ (row 68 , column 30 ). In scenario 6 , withdrawals from EB-810, EB-851, and EB-884, all located in the industrial district and screened in the " 2,000 -foot" sand (fig. 9), were reduced by a total of $1.4 \mathrm{Mgal} / \mathrm{d}$ from their 2007 withdrawal rates. The "scavenger well couple" consists of a lower well that withdraws $1 \mathrm{Mgal} / \mathrm{d}$ from the base of the "2000-foot" sand (layer 18) and an upper well that withdraws $1.5 \mathrm{Mgal} / \mathrm{d}$ from the upper third of the "2000-foot" sand (layers 9-11). Because the $1.5 \mathrm{Mgal} / \mathrm{d}$ withdrawn from the upper well may be usable for public supply, $1.5 \mathrm{Mgal} / \mathrm{d}$ of compensating withdrawal reductions (with respect to 2007 rates) were specified from five public supply wells, including EB-151, EB-630, EB-774, EB-814, and EB-1150 (fig. 9). Well EB-151 is screened in both the "2,000-foot" sand and the "2,400-foot" sand. Because zero withdrawals were specified from well EB-151 in scenario 6, where water levels within the "2,400foot" sand are higher than within the "2,000-foot" sand, up to $0.35 \mathrm{Mgal} / \mathrm{d}$ (242 gpm) of water flows through EB-151 from the "2,400-foot" sand into the "2,000-foot" sand after 2017. In scenario 6 , total simulated withdrawals from the "2,000-foot" sand north of the fault remained at $25.3 \mathrm{Mgal} / \mathrm{d}$ during 2007-14, decreased to $23.9 \mathrm{Mgal} / \mathrm{d}$ during 2015-16, then increased to $24.9 \mathrm{Mgal} / \mathrm{d}$ during 2017-47.

The saltwater plume continues to migrate toward the industrial district in scenario 6 (fig. 36), but the concentrations within the plume are lower than those simulated for scenario 1. The chloride concentration simulated for 2047 is reduced from 187 to $115 \mathrm{mg} / \mathrm{L}$ at well EB-X (fig. 30), which is a smaller reduction than those simulated for scenarios 3,4 , or 5 . Scenario 6 predicts the smallest plume area and lowest mean and median chloride concentration in 2047 (table 6), which suggests it is more effective in reducing saltwater concentrations within the "2,000-foot" sand in the Baton Rouge area. 


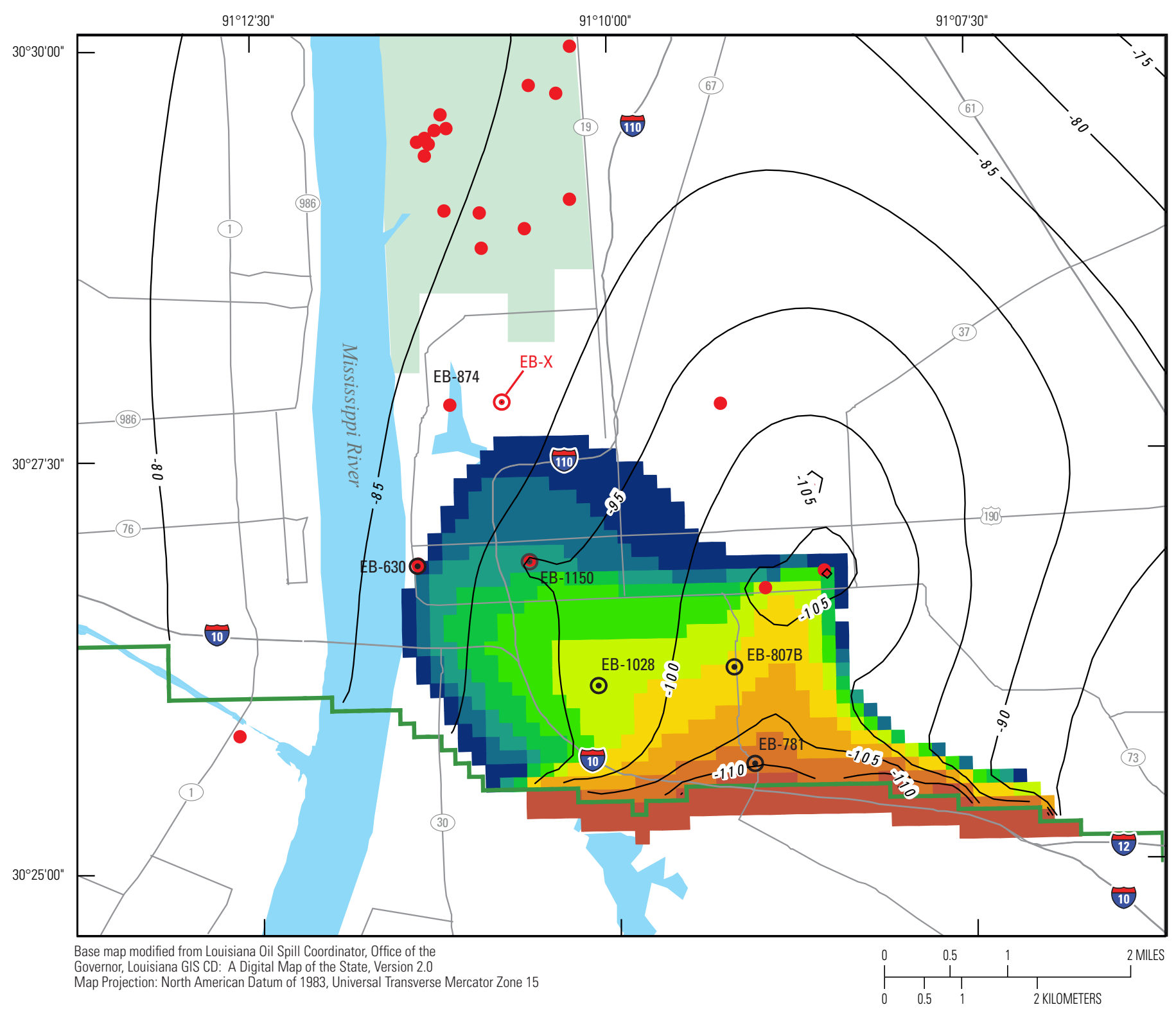

EXPLANATION

Figure 35. Map showing predicted 2047 water levels and chloride concentrations at the base of the "2,000-foot" sand of the Baton Rouge area in the detailed model area in southeastern Louisiana following cessation of pumping from the "2000-foot" sand in the Baton Rouge industrial district beginning in 2015 (scenario 5). 


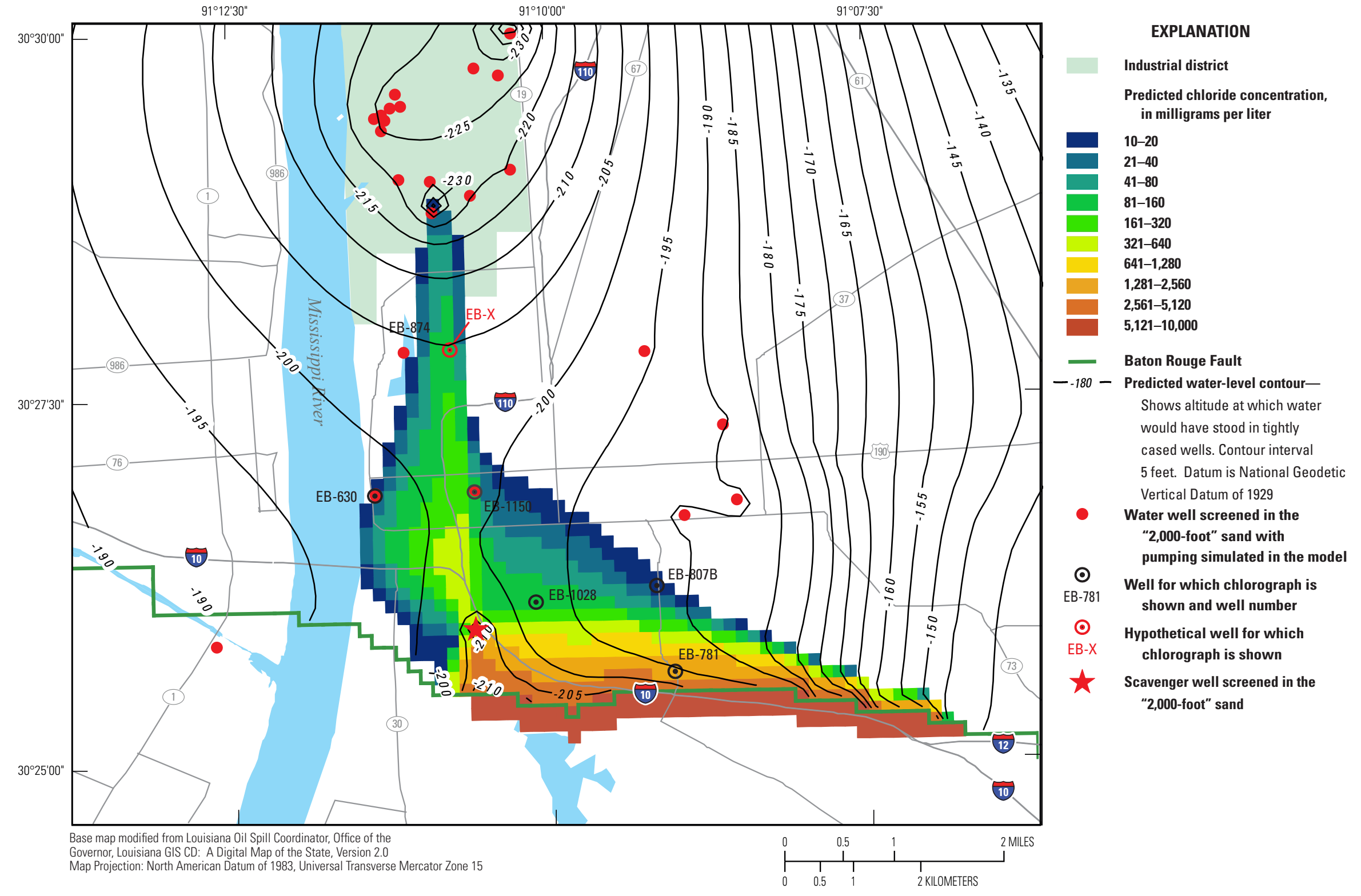

Figure 36. Map showing predicted 2047 water levels and chloride concentrations at the base of the "2,000-foot" sand of the Baton Rouge area in the detailed model area in southeastern Louisiana after 31 years of pumping from a scavenger well located in model row 68 and column 30 beginning in 2017 and reduced withdrawals at selected industrial and public supply wells beginning in 2015 (scenario 6). 


\section{Summary}

Groundwater withdrawals in the Baton Rouge area since the 1940s have lowered water levels and altered groundwaterflow directions in the freshwater aquifers of the Southern Hills aquifer system. Generally, aquifers south of the Baton Rouge Fault contain saltwater, and aquifers north of the fault contain freshwater. The drawdown of groundwater levels has caused saltwater to encroach into previously freshwater areas in the Baton Rouge area. Saltwater encroachment has been detected north of the Baton Rouge Fault in East Baton Rouge Parish in 7 of the 10 Baton Rouge sands, including the "1,500-foot" sand and "2,000-foot" sand. The 10 aquifers that underlie the Baton Rouge area, which includes East and West Baton Rouge Parishes, Pointe Coupee Parish, and East and West Feliciana Parishes, provided about 167 million gallons per day (Mgal/d) for public supply and industrial use in 2010. Groundwater withdrawals from the "2,000-foot" sand, which totaled 23.9 $\mathrm{Mgal} / \mathrm{d}$ during 2010, have resulted in measured water-level drawdowns as great as 356 feet (ft) and saltwater migration from south of the fault into the "2,000-foot" sand. This saltwater threatens industrial wells located about 3 miles (mi) north of the fault. A groundwater flow and saltwater transport model was constructed to assess the effects of groundwater withdrawals on the rate and pathways of saltwater migration.

Because density differences between groundwater areas with contrasting saltwater concentrations may affect groundwater flow between those areas, both constant- and variable-density simulations of groundwater flow were utilized. The groundwater-flow simulation was initially constructed with MODFLOW and calibrated to observed water levels with PEST. The calibrated groundwater-flow model parameters were subsequently utilized for the variabledensity SEAWAT version of the model, which simulated both groundwater flow and solute transport. Although much of the model input for SEAWAT is identical to MODFLOW input, withdrawal fluxes previously computed with the MODFLOW multi-node well package were used to specify WEL package input for SEAWAT. Additional input was constructed to define transport boundary and initial conditions, transport properties, and specification of the equation of state relating solute concentration to groundwater density. The groundwater flow and solute-transport equations are coupled because SEAWAT iteratively solves each equation for every transport time step such that computed concentrations affect groundwater density and can therefore influence groundwater velocities.

A three-dimensional hydrogeologic framework was constructed to define the extents and thicknesses of the aquifers and confining units in the study area. The framework consists of 22 layers that represent the entire sequence of sands and clays from land surface to the base of the " 2,800 foot" sand. Layers 1, 3, 5, 7, 9-18, 20, and 22 compose the aquifer layers. Layers 2, 4, 6, 8, 19, and 21 compose the confining units that separate aquifer layers. Layers 1 and 3 represent multiple aquifers that have similar hydraulic characteristics and are likely interconnected. Layer 1 represents the Mississippi River alluvial aquifer, shallow sands, upland terrace aquifer, and the " 400 -foot" sand, "600foot" sand, and " 800 -foot" sand. Layer 3 includes the "1,000foot" sand and " 1,200 -foot" sand. The " 2,000 -foot" sand is represented by 10 layers numbered 9 through 18 .

A finite-difference grid with lateral cell dimensions of 500 by $500 \mathrm{ft}$ in the Baton Rouge area has increasing cell spacing toward the model-domain boundaries so that the entire 6,529 square mile study area is discretized with 85 rows and 85 columns of finite-difference cells. Vertical finitedifference discretization was defined such that model-cell layers correspond to the tops of hydrogeologic framework units north of the Baton Rouge Fault and are horizontal along columns from the fault southward. Because the Hydrogeologic Unit-Flow Package was used to define the hydrogeologic framework geometry independently from finite-difference discretization, this discretization scheme facilitated simulation of flow between hydrogeologic units where they are juxtaposed at the Baton Rouge Fault. Additional resistance to flow across the Baton Rouge Fault was simulated with horizontal flow barriers. Following an initial steady-state stress period that simulated predevelopment conditions prior to 1940,68 annual transient stress periods simulated time from 1940 through 2007. The period from 2008 through 2011 was simulated with 2007 withdrawal rates. Three additional stress periods were used for scenarios that simulate future conditions through 2047.

Boundary conditions utilized for the groundwater-flow simulation included specified flux, specified head, and headdependent flux types. Transient water levels within the top model layer, which represents the " 400 -foot" sand, "600foot" sand, and "800-foot" sand, were specified by linear interpolation between levels constructed for 1944, 1980, 1984, 1990, 1998, 1999, and 2004. Water levels in the top model layer for simulated times before 1944 and after 2004 were specified at the 1944 and 2004 levels, respectively. A constant-head boundary was specified along row 85 in the bottom model layer, which corresponds to the southernmost extent of the "2,800-foot" sand. The water-level for this boundary, which was estimated as a parameter during model calibration, enabled simulation of underflow to and from areas south of the simulated aquifer system. The remaining lateral and lower boundaries of the flow domain were simulated as no-flow boundaries. The layer-by-layer withdrawals simulated by the MODFLOW multi-node well package depend upon water levels simulated in the model layers in which wells have screens and are therefore head-dependent fluxes. The equivalent fluxes specified using the WEL package in the SEAWAT simulation are the specified-flux type.

Average daily withdrawal rates were specified for 605 wells with the multi-node well package for each annual stress period from 1940 through 2007. After calibration of the MODFLOW model, the simulated layer-by-layer fluxes in and out of each well were specified as WEL package input for the SEAWAT simulation. 
The area in which solute transport was simulated with SEAWAT is a subset of the flow model domain and corresponds to the 50 row by 55 column portion of the grid with 500 by $500 \mathrm{ft}$ finite-difference cells in the Baton Rouge area. Model-grid cells within this area south of the Baton Rouge Fault are constant-concentration boundaries; cells north of the fault are variable-concentration cells for which a concentration was calculated for each transport time step.

The initial chloride concentration within model-grid cells adjacent to the south side of the Baton Rouge Fault, east of column 30, and from model-grid layers 9 through 18 (inclusive) was specified to increase linearly with depth from zero to a maximum concentration, which was parameterized and estimated during model calibration to be 10,000 milligrams per liter $(\mathrm{mg} / \mathrm{L})$. These model grid layers are laterally connected to the 10 layers that simulate the " 2,000 foot" sand north of the fault. All other portions of the solute transport domain were assigned a zero initial concentration.

The groundwater-flow model was calibrated to 3,612 water levels measured between 1940 and 2007 from 137 observation wells with the parameter-estimation code PEST. Additional water levels were used to evaluate the accuracy of the specified-head boundaries in the top model layer and the fit of simulated-to-observed water levels during the period 2008 through 2011. The estimated values of hydraulic property parameters were all within the range considered reasonable.

Six hypothetical scenarios simulated the effects of different groundwater withdrawal options on groundwater levels within the "1,500-foot" sand and the "2,000-foot" sand and the transport of saltwater within the "2,000-foot" sand. All scenarios simulated 2007 withdrawal rates for a 7-year period from 2008 through 2014 and various withdrawal options during three subsequent periods that simulate 2015 through 2047. Scenario 1 is considered a base case for comparison to the other five scenarios and simulates continuation of 2007 reported groundwater withdrawals. Scenario 2 simulates discontinuation of withdrawals from seven selected industrial wells located in the northwest corner of East Baton Rouge Parish that are screened either in the "1,500-foot" sand or an adjacent aquifer. Water levels within the "1,500-foot" sand were predicted to be about 10 to $12 \mathrm{ft}$ higher under this withdrawal scenario than under scenario 1.

Four other scenarios test various groundwater withdrawal options on the water levels and predicted chloride concentrations within the "2,000-foot" sand. Scenario $3 \mathrm{a}$ and $3 \mathrm{~b}$ simulate the effects of a scavenger well that withdraws 2.0 Mgal/d from the base of the "2,000-foot" sand at two possible locations on water levels and concentrations within the "2,000-foot" sand. Scenario 4 simulates a $3.6 \mathrm{Mgal} / \mathrm{d}$ reduction in total groundwater withdrawals from selected wells screened in the "2,000-foot" sand that are located in the Baton Rouge industrial district. Scenario 5 simulates the effect of total cessation of groundwater withdrawals from the "2,000-foot" sand in the industrial district. Scenario 6 simulates the combined effect of a $1.4 \mathrm{Mgal} / \mathrm{d}$ withdrawal reduction from the industrial district, a scavenger well that withdraws $1.0 \mathrm{Mgal} / \mathrm{d}$ from the base of the "2000-foot" sand, a well that withdraws $1.5 \mathrm{Mgal} / \mathrm{d}$ from the upper third of the "2000-foot" sand at the scavenger location, and $1.5 \mathrm{Mgal} / \mathrm{d}$ of total withdrawal reductions from other public-supply wells screened in the "2000-foot" sand.

In comparison to the concentrations simulated in scenario 1, operation of the scavenger well in the locations specified in scenario 3 reduces the chloride concentrations at all existing chloride-observation well locations. In scenario 4 , the concentration decreased in the leading portion of the plume south of the industrial district but increased in other areas; the size of the plume area and median, and mean chloride concentrations are similar to scenario 1 . The chlorideconcentration distribution in scenario 5 reflects the change in groundwater-flow direction toward municipal supply wells in the area of drawdown about 1.5 mi north of the Baton Rouge fault, where chloride concentrations increased in comparison to scenario 1. Although scenario 6 simulated a smaller concentration reduction at EB-X (south of the industrial district), it was most effective at decreasing the size of the plume area and median and mean chloride concentrations within the "2000-foot" sand in the Baton Rouge area.

\section{Selected References}

Anderman, E.R., and Hill, M.C., 2000, MODFLOW-2000, The U.S. Geological Survey modular ground-water model-Documentation of the Hydrogeologic-Unit Flow (HUF) package: U.S. Geological Survey Open-File Report 00-342, 89 p.

Bates, R.L., and Jackson, J.A., eds., 1984, Dictionary of geological terms (3d ed.): New York, Doubleday, 571 p.

Boswell, E.H., and Arthur, J.K., 1988, Generalized potentiometric surface of shallow aquifers in southern Mississippi, 1982: U.S. Geological Survey Water-Resources Investigations Report 87-4257, 1 sheet.

Buono, Anthony, 1983, The Southern Hills regional aquifer system of southeastern Louisiana and southwestern Mississippi: U.S. Geological Survey Water-Resources Investigations Report 83-4189, 38 p.

Calhoun, Milburn, and Frois, Jeanne, eds., 1997, Louisiana almanac (1997-98 ed.): Gretna, La., Pelican Publishing Company, 695 p.

Dial, D.C., and Cardwell, G.T., 1999, A connector well to protect water-supply wells in the "1,500-ft" sand of the Baton Rouge, Louisiana area from saltwater encroachment: Capital Area Ground Water Conservation Commission Bulletin no. 5, 17 p.

Doherty, John, 2003, Ground water model calibration using pilot points and regularization: Ground Water, v. 41, no. 2, p. 170-177.

Doherty, John, 2004, PEST-Model-independent parameter estimation, user manual (5th ed.): Corinda, Australia, Watermark Numerical Computing, $336 \mathrm{p}$. 
Draper, N.R., and Smith, Harry, 1998, Applied regression analysis, $3^{\text {rd }}$ ed: John Wiley \& Sons, New York, NY, 706 p.

Durham, C.O., Jr., and Peeples, E.M., III, 1956, Pleistocene fault zone in southeastern Louisiana [abs.]: New Orleans, La., Transactions of the Gulf Coast Association of Geological Societies, v. 6, p. 65-66.

Griffith, J.M., 2003, Hydrogeologic framework of southeastern Louisiana: Louisiana Department of Transportation and Development Water Resources Technical Report no. 72, 21 p., $18 \mathrm{pl}$.

Halford, K.J., and Lovelace, J.K., 1994, Analysis of ground-water flow in the "1,200-foot" aquifer, Baton Rouge area, Louisiana: Louisiana Department of Transportation and Development Water Resources Technical Report no. 54, 68 p.

Hanor, J.S., 1982, Reactivation of fault movement, Tepetate fault zone, south central Louisiana, in Transactions of the Gulf Coast Association of Geological Societies: Gulf Coast Association of Geological Societies, v. 32, p. 237-245.

Harbaugh, A.W., 2005, MODFLOW-2005, the U.S. Geological Survey modular ground-water model-The ground-water flow process: U.S. Geological Survey Techniques and Methods 6-A16 [variously paged].

Harbaugh, A.W., Banta, E.R., Hill, M.C., and McDonald, M.G., 2000, MODFLOW-2000, the U.S. Geological Survey modular ground-water model-User guide to modularization concepts and the ground-water flow process: U.S. Geological Survey Open-File Report 00-92, $121 \mathrm{p}$.

Heywood, C.E., and Griffith, J.M., 2013, Simulation of groundwater flow in the "1,500-foot" sand and "2,000-foot" sand and movement of saltwater in the "2,000-foot" sand of the Baton Rouge area, Louisiana: U.S. Geological Survey Open-File Report 2013-1153, 79 p.

Hill, M.C., and Tiedeman, C.R., 2007, Effective groundwater model calibration - With analysis of data, sensitivities, predictions, and uncertainty: Hoboken, N.J., Wiley, 455 p.

Hsieh, P.A., and Freckleton, J.R., 1993, Documentation of a computer program to simulate horizontal-flow barriers using the U.S. Geological Survey's modular three-dimensional finite-difference ground-water flow model: U.S. Geological Survey Open-File Report 92-477, 32 p.

Huntzinger, T.L., Whiteman, C.D., Jr., and Knochenmus, D.D., 1985, Simulation of ground-water movement in the "1,500- and 1,700-foot" aquifer of the Baton Rouge area, Louisiana: Louisiana Department of Transportation and Development, Office of Public Works Water Resources Technical Report no. 34, 52 p.

Kazmann, R.G., 1970, The present and future ground-water supply of the Baton Rouge area: Baton Rouge, La., Louisiana State University, Louisiana Water Resources Research Institute Bulletin 5, 44 p.
Kernodle, J.M., and Philip, R.D., 1988, Using a geographic information system to develop a ground-water flow model: American Water Resources Association Monograph, series no. 14, p. 191-202.

Konikow, L.F., Hornberger, G.Z., Halford, K.J., and Hanson, R.T., 2009, Revised multi-node well (MNW2) package for MODFLOW ground-water flow model: U.S. Geological Survey Techniques and Methods 6-A30, $67 \mathrm{p}$.

Kuniansky, E.L., 1989, Geohydrology and simulation of ground-water flow in the "400-foot," "600foot," and adjacent aquifers, Baton Rouge area, Louisiana: Louisiana Department of Transportation and Development Water Resources Technical Report no. 49, 90 p.

Langevin, C.D., Shoemaker, W.B., and Guo, Weixing, 2003, MODFLOW-2000, the U.S. Geological Survey modular groundwater model-Documentation of the SEAWAT-2000 version with the variable-density flow process (VDF) and the integrated MT3DMS transport process (IMT): U.S. Geological Survey OpenFile Report 03-426, 43 p.

Leake, S.A., and Lilly, M.R., 1997, Documentation of a computer program (FHB1) for assignment of transient specified-flow and specified-head boundaries in applications of the Modular FiniteDifference Ground-Water Flow Model (MODFLOW): U.S. Geological Survey Open-File Report 97-571, 56 p.

Lovelace, J.K., 2007, Chloride concentrations in ground water in East and West Baton Rouge Parishes, Louisiana, 2004-05: U.S. Geological Survey Scientific Investigations Report 2007-5069, 27 p.

Lovelace, J.K., and Lovelace, W.M., 1995, Hydrogeologic unit nomenclature and computer codes for aquifers and confining units in Louisiana: Louisiana Department of Transportation and Development Water Resources Special Report no. 9, 12 p.

Marsily, Ghislain de, 1986, Quantitative hydrogeology: San Diego, Calif., Academic Press, 440 p.

Martin, Angel, Jr., and Whiteman, C.D., Jr., 1985, Map showing generalized potentiometric surface of aquifers of Pleistocene Age, southern Louisiana, 1980: U.S. Geological Survey Water-Resources Investigations Report 84-4331, 1 sheet.

Martin, Angel, Jr., and Whiteman, C.D., Jr., 1990, Calibration and sensitivity analysis of a ground-water flow model of the coastal lowlands aquifer system in parts of Louisiana, Mississippi, Alabama, and Florida: U.S. Geological Survey Water-Resources Investigations Report 89-4189, 54 p.

McCulloh, R.P., 1991, Surface faults in East Baton Rouge Parish: Baton Rouge, La., Louisiana Geological Survey Open-File series $91-02,25 \mathrm{p}$.

Meyer, R.R., and Rollo, J.R., 1965, Saltwater encroachment, Baton Rouge area, Louisiana: Department of Conservation, Louisiana Geological Survey, and Louisiana Department of Public Works Water Resources Pamphlet 17, 9 p.

Meyer, R.R., and Turcan, A.N., Jr., 1955, Geology and ground-water resources of the Baton Rouge area, Louisiana: U.S. Geological Survey Water-Supply Paper 1296, 138 p. 
Morgan, C.O., 1961, Ground-water conditions in the Baton Rouge area, 1954-59, with special reference to increased pumpage: Department of Conservation, Louisiana Geological Survey, and Louisiana Department of Public Works Water Resources Bulletin $2,78 \mathrm{p}$.

Morgan, C.O., 1963, Ground-water resources of East Feliciana and West Feliciana Parishes, Louisiana: Louisiana Department of Public Works, 58 p.

Morgan, C.O., and Winner, M.D., Jr., 1964, Saltwater encroachment in aquifers of the Baton Rouge area-Preliminary report and proposal: Louisiana Department of Public Works, 37 p.

Murray, G.E., 1961, Geology of the Atlantic and Gulf Coastal Province of North America: New York, Harper Brothers, 692 p.

National Oceanic and Atmospheric Administration, 1995, Climatological data annual summary_Louisiana: Asheville, N.C., Environmental Data Service, 23 p.

Newcome, Roy, Jr., 1975, The Miocene aquifer system in Mississippi: U.S. Geological Survey Water-Resources Investigations Report 46-75.

Orzol, L.L., 1997, User's guide for MODTOOLS - Computer programs for translating data of MODFLOW and MODPATH into geographic information system files: U.S. Geological Survey Open-File Report 97-240, 86 p.

Rollo, J.R., 1969, Saltwater encroachment in aquifers of the Baton Rouge area, Louisiana: Department of Conservation, Louisiana Geological Survey, and Louisiana Department of Public Works Water Resources Bulletin 13, 45 p.

Sargent, B.P., 2011, Water use in Louisiana, 2010: Louisiana Department of Transportation and Development Water Resources Special Report no. 17, 135 p.

Smith, C.G., 1979, A geohydrologic survey of the "1,200-foot" aquifer in the Capital Area Ground Water Conservation District: Capital Area Ground Water Conservation Commission Bulletin 3, $19 \mathrm{p}$.

Smith, C.G., and Kazmann, R.G., 1978, Subsidence in the Capital Area Ground Water Conservation District-An update: Baton Rouge, La., Capital Area Ground Water Conservation Commission Bulletin 2, 31 p.

Smoot, C.W., 1988, Louisiana hydrologic atlas map no. 3-Altitude of the base of freshwater in Louisiana: U.S. Geological Survey Water-Resources Investigations Report 86-4314, 1 sheet.

Stuart, C.G., Knochenmus, Darwin, and McGee, B.D., 1994, Guide to Louisiana's ground-water resources: U.S. Geological Survey Water-Resources Investigations Report 94-4085, 55 p.

Tomaszewski, D.J., 1996, Distribution and movement of saltwater in aquifers in the Baton Rouge area, Louisiana, 1990-92: Louisiana Department of Transportation and Development Water Resources Technical Report no. 59, 44 p.
Tomaszewski, D.J., and Accardo, Darren, 2004, Louisiana groundwater map no. 19-Potentiometric surface of the "2,400-foot" sand of the Baton Rouge area, Louisiana, May-June 2002: U.S. Geological Survey Scientific Investigations Map 2865, 2 sheets.

Torak, L.J., and Whiteman, C.D., Jr., 1982, Applications of digital modeling for evaluating the ground-water resources of the "2,000-foot" sand of the Baton Rouge area, Louisiana: Louisiana Department of Transportation and Development, Office of Public Works Water Resources Technical Report no. 27, 87 p.

U.S. Census Bureau, 2010, Annual estimates of the population for counties of Louisiana-April 1, 2000, to July 1, 2004 (CO-EST2004-01-22): accessed June 19, 2006, at http://www.census.gov/popest.

U.S. Geological Survey, 2013, Water quality samples for Louisiana: National Water Information System Web Interface, accessed on 12/7/13 at http://waterdata.usgs.gov/la/nwis/uv/?referred_ module $=$ gw.

Viewlog Systems, 2004, VIEWLOG borehole data management system: Toronto, Ontario, Canada, Viewlog Systems, 465 p.

Whiteman, C.D., Jr., 1979, Saltwater encroachment in the "600-foot" and "1,500-foot" sands of the Baton Rouge area, Louisiana, 196678 , including a discussion of saltwater in other sands: Louisiana Department of Transportation and Development, Office of Public Works Water Resources Technical Report no. 19, 49 p.

Winner, M.D., Jr., Forbes, M.J., Jr., and Broussard, W.L., 1968, Water resources of Pointe Coupee Parish, Louisiana: Department of Conservation, Louisiana Geological Survey, and Louisiana Department of Public Works Water Resources Bulletin 11, 110 p.

Zheng, Chunmiao, 2010, MT3DMS v. 5.3-Supplemental user's guide: Tuscaloosa, Ala., University of Alabama, Department of Geological Sciences, 51 p.

Zheng, Chunmiao, and Bennett, G.D., 1995, Applied contaminant transport modeling: New York, Van Nostrand Reinhold, 440 p.

Zheng, Chunmiao, and Wang, P.P., 1999, MT3DMS-A modular three-dimensional multispecies transport model for simulation of advection, dispersion and chemical reactions of contaminants in ground-water systems; documentation and user's guide: Jacksonville, Fla., U.S. Army Corps of Engineers Contract Report SERDP-99-1, 221 p.
Publishing support provided by Lafayette Publishing Service Center 
